NBER WORKING PAPER SERIES

THE ROLE OF INDUSTRIAL COUNTRY POLICIES IN EMERGING MARKET CRISES

Jeffrey A. Frankel

Nouriel Roubini

Working Paper 8634

http://www.nber.org/papers/w8634

\author{
NATIONAL BUREAU OF ECONOMIC RESEARCH \\ 1050 Massachusetts Avenue \\ Cambridge, MA 02138 \\ December 2001
}

The authors both served in the US Administration during the late 1990s. They wish to thank Ronald Mendoza for research assistance, and Gordon de Brouwer, Martin Feldstein, Mervyn King, Allan Meltzer, Robert Rubin, and George Soros for comments. The usual disclaimers apply with stronger force. This chapter was written for an NBER conference in Woodstock, Vermont, October 2000, organized by Martin Feldstein, and was heavily revised in August 2001. The views expressed herein are those of the authors and not necessarily those of the National Bureau of Economic Research.

(C) 2001 by Jeffrey A. Frankel and Nouriel Roubini. All rights reserved. Short sections of text, not to exceed two paragraphs, may be quoted without explicit permission provided that full credit, including $(\mathrm{C}$ notice, is given to the source. 
The Role of Industrial Country Policies in Emerging Market Crises

Jeffrey A. Frankel and Nouriel Roubini

NBER Working Paper No. 8634

December 2001

JEL No. F3, F33, F34, O19

\begin{abstract}
This paper considers policies of the industrialized countries, as they pertain to crises in emerging markets. These fall into three areas: (1) their own macroeconomic policies, which determine the global financial environment; (2) their role in responding to crises when they occur, particularly through rescue packages, which have three components -- reforms in debtor countries, public funds from creditor countries, and private sector involvement; and (3) efforts to reform the international financial architecture, with the aim of lessening the frequency and severity of future crises. A recurrent theme is the tension between mitigating crises that occur, and the moral hazard that such efforts create in the longer term. In addition to reviewing these three areas of policy, we consider the institutions through which the more powerful countries exercise their influence. We conclude with a discussion of the debate over the sins of the International Monetary Fund, and proposals for reform.
\end{abstract}

Jeffrey Frankel

Harvard University

Kennedy School of Government

79 JFK Street

Cambridge, MA 02140

and NBER

Jeffrey_Frankel@Harvard.edu
Nouriel Roubini

Department of Economics, KMC 7-83

Stern School of Business, New York University

44 West 4th Street

New York, NY 10012

and NBER

nroubini@stern.nyu.edu 


\title{
The Role of Industrial Country Policies in Emerging Market Crises
}

\section{$\underline{\text { Outline }}$}

\section{G-7 Macroeconomic Policies}

\author{
A. Monetary Policy, Fiscal Policy, and Growth \\ Business cycles \\ National saving rates \\ The role of interest rates in the United States and other major countries \\ B. G-7 Exchange rates \\ Did a rise in the yen/dollar rate cause the East Asia crisis? \\ The proposal for a $G$-3 target zone \\ C. Industrial Country Trade Policies

\section{Crisis Management}

\author{
A. Modalities of Coordination \\ G-7 Finance Ministers and Deputies \\ Coordination among Central Bankers and the BIS \\ Paris Club \\ Other government agencies and heads of state \\ B. The Role of the $\mathrm{G} 3$ \\ Lack of domestic US support for internationalism \\ The US Congress \\ C. Moral Hazard and Private Sector Involvement (PSI) in Crisis Resolution \\ Introduction \\ Moral Hazard \\ Issues with standstills \\ The G7 PSI framework and its application to bonded debt \\ Collective Action Clauses: Are they overrated? \\ Lessons from recent cases studies of bonded debt restructuring \\ Concluding Remarks on PSI
}

\section{The Architecture to Reform the Architecture}
A. Halifax Summit and Rey Report
B. G-22 Working Groups (\& G-33)
C. G-7 Kohln and Okinawa Summits 


\section{New Groups}

The International Monetary and Financial Committee (IMFC)

The $G-20$

The Financial Stability Forum (FSF)

\section{Reforms for Better Crisis Prevention}
A. Transparency and accountability
B. BIS capital adequacy standards and their implication for crisis prevention
C. Highly Leveraged Institutions and Hedge Funds
D. Private Contingent Credit Lines
E. Vulnerability indicators

\section{Policy Regarding Reform of the IMF}
A. The Nature of IMF Critiques
B. The Meltzer Commission Report
C. Mission Creep
D. Recent G-7 Initiatives to Reform the IMF

\section{Proposals for Alternative Institutions and Tools for Crisis Prevention/Resolution}

\section{A. International lenders of last resort (ILOLR) \\ Full bail-out (an ILOLR function) or full bail-in? Some conceptual issues}

ILOLR, Too Big to Fail (TBTF) doctrine and appropriate PSI

B. Some specific proposals for new institutions

The Asian Monetary Fund

Global financial super-regulator (Kaufman)

Proposal for international deposit insurance (Soros)

C. Other Proposals for Mechanisms/Tools to Prevent and Resolve Financial Crises

Collateral and credit enhancements: creating value out of thin air, or redistribution of value?

Alternative ideas for the process of debt restructuring (CFR initiative)

\section{Conclusions}




\title{
The Role of Industrial Country Policies in Emerging Market Crises
}

\author{
Jeffrey Frankel and Nouriel Roubini
}

A search for the causes and solutions of crises in emerging markets must begin with the policies of the countries themselves. Nevertheless, policies of the industrialized countries are relevant as well. That is the topic of this chapter. It covers everything from the macroeconomic policies of the G-7 countries themselves, to their role via the G7 and IMF in managing international crises when they break out, to their role in seeking to reform the international financial architecture so as to reduce to whatever extent possible the frequency and severity of future crises. A theme throughout the chapter will be the moral hazard question - the tension between the desirability of reducing the adverse consequences of any given crisis, on the one hand, and the danger that such efforts will in the longer term encourage capital flows that are larger, more careless, and more likely to result in future crises, on the other hand.

\section{G-7 Macroeconomic Policies}

Nothing that the industrialized countries do, at least in the short run, has as big an effect on economic developments in emerging market countries as their macroeconomic policies. U.S. monetary contractions, for example, were among the most important causes, in a proximate sense, of the international debt crisis that began in 1982 and the Mexican peso crisis of 1994. A global easing of monetary policy in the fall of 1998 helped bring the most recent round of crises to an end. Indeed, there is evidence that asset prices in emerging markets are more sensitive to short-term U.S. interest rates than are comparable asset prices in the United States itself.

Three macroeconomic variables among industrialized countries that have major short-term impact on developing countries are growth rates, real interest rates, and exchange rates. Trade policy in industrialized countries is very important as well. We consider each in turn.

\section{A. Monetary Policy, Fiscal Policy, and Growth}

This paper will not generally try to explain growth rates and interest rates in the industrialized countries, but rather, in this section, to look at their effects on emerging markets. Nevertheless, we begin with a parenthetical aside regarding the sources of growth. Monetary and fiscal policies are traditionally viewed as affecting real growth rates in the short run. They can't fully explain rapid US growth in the 1990s, however, or rapid Japanese growth in earlier decades. Longer term supply or productivity determinants are clearly important. In the 1980s, many observers thought that the Japanese brand of capitalism had proven its superiority. In the 1990s, many considered that, to the contrary, the US model had proven its superiority. Perhaps the attractions of Japan as a role model in the 1980s, followed by the United States in the 1990s, have had 
effects on developing country thinking that are ultimately more important than the immediate economic effects of growth rates in these and other industrialized countries. But, in any case, it is the latter topic that concerns us here.

\section{I.A.1 Business cycles}

Incomes in developing countries are procyclical, rising when growth rates in the industrialized countries are strong, falling when they are not. The most visible channel of transmission is trade. When incomes in the rich world fall, their imports from developing countries fall as well. This is important because export revenue is key to the ability of poor countries to service debts. Demand for the types of goods that developing countries produce tends to be unusually procyclical. ${ }^{1}$ The impact of OECD slowdowns hits in three ways -- lower quantities demanded, lower prices on world markets, and the raising of import barriers.

To take an example, the recession among industrialized countries in 1980-82 depressed prices and volumes for exports from developing countries, reversing a preceding period of boom. This in turn contributed to the international debt crisis of the 1980s. To take another example, Mexico's 1995 recovery from the peso crisis was aided by rapid US economic growth. With NAFTA in place in 1994, Mexican exports to the United States -- which were 85 per cent of its total exports -- were able to grow 92 per cent from 1994 to $1999 .^{2}$ When East Asia was hit by its currency crises in 1997-98, by contrast, recovery was hampered by the absence of economic growth in the leading regional economy, as Japan remained mired in recession. Japan's G-7 partners at the time urged reflation in Tokyo; among other reasons was the need to promote growth in the rest of East Asia. For all the talk of globalization and of the irrelevance of geography, economic prospects in each region of the world are affected particularly strongly by the growth rate of the largest industrialized countries in that region.

A simple regression estimate illustrates the dependence of emerging market economies on the cyclical position of the bigger countries. Every one percentage point increase in G-7 growth raises the growth rate among market borrowers an estimated .78 percentage points. ${ }^{3}$

\footnotetext{
${ }^{1}$ Goldstein and Khan (1985).

${ }^{2}$ In current dollars. The source is IFS Direction of Trade.

${ }^{3}$ Statistically significant at the $95 \%$ level. The $\mathrm{R}^{2}$ is .23 . The period of estimation is $1977-1999$.
} 


\section{I.A.2. National saving rates}

Also critical to emerging markets, even for any given global growth rate, is the availability of capital, as reflected in global interest rates. The best indicator of the availability of capital is the real interest rate, that is, the nominal rate adjusted for expected inflation. An increase in the global inflation rate can for a time actually be good for developing countries. (This is true even if they are fully reflected in nominal interest rates.) The real value of pre-existing debt is reduced, relative to the prices of the commodities that they produce.

More broadly, the availability of capital is determined by the balance of saving and investment. The usual presumption is that there is an excess of potentially profitable investment opportunities in the developing world, attributable to its low capital/labor ratio, relative to available domestic saving. At least this is the presumption for those countries that have put into place the necessary pre-conditions for growth, such as a market economy and monetary stability, which are generally those countries that warrant the title "emerging markets." The usual presumption is also that the situation is the other way around in the industrialized world: an excess of saving over investment opportunities. As a result, the opening of capital markets results in the flow of capital from low interest rate rich countries to high interest rate emerging markets, to the benefit of both.

\section{Table 1: Trade and Current-Account Balances of Developing Countries (Annual average in US\$ billions)}

\begin{tabular}{|l|c|c|c|c|}
\hline \multicolumn{1}{|c|}{ Region } & $1977-1982$ & $1983-1990$ & $1991-1996$ & $1997-1999$ \\
\hline Trade Balances & & & & \\
\hline Developing Countries & 42 & 34 & -14 & 27 \\
\hline Africa & 3 & 5 & 5 & 2 \\
\hline Asia & -14 & -2 & -24 & 47 \\
\hline Middle East and Europe & 54 & 5 & 12 & 4 \\
\hline Western Hemisphere & -0.5 & 26 & -7 & -26 \\
\hline Current-Account Balances & & & & \\
\hline Market borrowers & -44 & -9 & -58 & -36 \\
\hline Developing Countries & -28 & -35 & -93 & -61 \\
\hline Africa & -15 & -7 & -10 & -15 \\
\hline Asia & -15 & -3 & -28 & 33 \\
\hline Middle East and Europe & 29 & -14 & -18 & -10 \\
\hline Western Hemisphere & -28 & -10 & -38 & -69 \\
\hline
\end{tabular}

Data from the World Economic Outlook.

Table 1 shows that developing countries have indeed been able to run current account deficits, financed by net capital inflows. But this general pattern varies, depending on circumstances. Inflows are cut off in the aftermath of crises. As the table 
shows, Latin American countries were obliged to switch to large trade surpluses in 198390, and Asian countries in 1997-99.

Demographically, the rapid aging of the population in most industrialized countries, particularly relative to the young populations in poor countries, implies that saving rates will fall in the former over the coming decades. Logically, baby boomers in the rich countries should have been saving at high rates in recent years, and investing part of those savings in high-return emerging markets, in order to develop a good portfolio of assets to draw down in their retirement years. But the trend in the 1980s and 1990s was in reality something quite different. National saving rates have not risen to prepare for the needs of social security deficits in the $21^{\text {st }}$ century, but the reverse.

U.S. national saving -- never high -- fell sharply in the 1980s, due to an increase in the federal budget deficit, exacerbated by a fall in private saving. This kept real interest rates high in the United States, and to some extent globally, and was a negative factor in the international debt situation of that decade. ${ }^{4}$ One view at the time was that the United States was deliberately pushing up its real interest rates (by a mix of tight money and loose fiscal policy) in order to attract capital, appreciate the dollar, and thereby put downward pressure on import prices and inflation. A particular version of this view was that the U.S. and Europe were involved in a competition to appreciate their currencies, that the outcome of this ultimately futile race was high world real interest rates. The developing countries, though innocent bystanders, were said to be the victims hardest-hit. The claim was that the G-7 countries should enter a cooperative agreement to refrain from attempts to appreciate their currencies, and thereby lower world real interest rates, as the biggest possible contribution to helping solve the international debt problem. ${ }^{5}$ Others pointed out, however, that the relevant government officials had not in fact raised real interest rates deliberately. ${ }^{6}$

In the late 1990s the United States solved its budget deficit problem. Record deficits were converted to record surpluses. As a direct consequence, national saving rose. The overall outlook for the saving-investment balance remains a concern, however. Investment in the United States in the 1990s rose even more rapidly than national saving. The "New Economy" offers a ready explanation for booming investment. In any case, the result of the investment boom has been an ever-increasing current account deficit, financed by capital on net flowing into the United States, rather than out. The United States in essence is competing with the developing world to attract capital. The U.S. current account deficit is far larger than those of all developing countries combined.

It is possible that over the next decade a depreciation of the dollar against the euro and yen will reduce the US current account deficit. But such a trend would probably also symmetrically reduce the current account surpluses of Europe and Japan. This would mean a rearrangement of the flow of funds among industrialized countries, rather than making more capital available for developing countries.

The outlook is for low availability of savings everywhere, not just in the United States. The reason is that the demographic problem is even worse in other industrialized countries than in the United States. European progress in reducing budget deficits under

\footnotetext{
${ }^{4}$ E.g., Dornbusch $(1985,346-47)$.

${ }^{5}$ Sachs (1985), McKibbin and Sachs (1988), and McKibbin and Sachs (1991).

${ }^{6}$ E.g., Feldstein (1994).
} 
the Maastrict Treaty in the 1990s is small compared to the looming liabilities represented by unfunded national retirement programs. Japan has the most rapidly aging population of all, and the fiscal expansion of the late 1990s has already pushed up previously low budget deficits and debt levels in that country. Nowhere are industrialized countries fully taking advantage of the opportunity to prepare for the coming retirement boom by saving heavily in their high-earning years and investing at substantial levels in younger developing countries. ${ }^{7}$

\section{I.A.3. The role of interest rates in the United States and other major countries}

On a yearly or monthly basis, fluctuations in interest rates (whether real or nominal) do not reflect changes in long-term fundamentals such as demographics, but rather reflect shorter-term factors. These include monetary policy and changes in attitudes toward liquidity and risk. Easy monetary policy among the industrialized countries in the 1970s meant low real interest rates; developing countries thus found it easy to finance their current account deficits, for example, by borrowing petrodollars recycled through banks in London and New York. The US monetary contraction of 1980-82, though it was eventually successful at reversing the high inflation rates of the 1970s, initially pushed up nominal and real interest rates sharply. This, as already noted, helped precipitate the international debt crisis of the 1980s.

In the early 1990s, interest rates in the United States and other industrialized countries were once again low. Investors looked around for places to earn higher returns, and discovered the emerging markets. There began what was in many ways the greatest flow of capital to developing countries in history. (The pre-World War I flow of finance from capital-rich Great Britain to land-rich Argentina, Australia and Canada still holds the record when expressed as a percentage of income. But the flows of the 1990s were far larger in absolute terms, and more of a global phenomenon.)

During 1992-94, Calvo, Leiderman and Reinhart -- and some other authors at the World Bank and International Monetary Fund -- produced a series of research papers examining the new capital flow phenomenon. They enumerated the possible underlying factors, attempted econometric estimation, and generally came to a surprising conclusion: the most important identifiable factors behind the flows were US interest rates and other macroeconomic variables external to the emerging market countries. Capital was heading South because low rates of return were on offer in the North.

This was a surprising conclusion because the more common belief at the time was that domestic factors within the emerging market countries were responsible, particularly pro-market policy reforms: monetary stabilization, privatization, deregulation, and the opening of economies to both trade and capital flows. Other candidate explanations were reduction of the existing debt burden under the Brady Plan, which had been launched in 1989 with Mexico as the first case; and institutional innovations in the investor community that made diversification into emerging markets more convenient, such as country funds, American Depository Receipts, and Global Depository Receipts. But the econometric studies reached the rough consensus that external macroeconomic factors were a major cause, perhaps the major cause of the increased demand for assets in emerging countries.

\footnotetext{
${ }^{7}$ E.g., B. Fischer and Reisen, 1994.
} 
Calvo, Leiderman and Reinhart (1993, p. 136-37) found that "foreign factors account for a sizeable fraction (about 50 per cent) of the monthly forecast error variance in the real exchange rate... [and]...also account for a sizable fraction of the forecast error in monthly reserves." Chuhan et al (1994) estimated that US factors explained about half of portfolio flows to Latin America (although less than country factors in the case of East Asia). Fernandez-Arias (1994) found that the fall in US returns was the key cause of the change in capital flows in the 1990s. Dooley et al (1994) in a study of the determinants of the increase in secondary debt prices among 18 countries concluded that "International interest rates are the key factor." It is worth emphasizing that all these papers were written before the Mexican crisis of December 1994, during a period when most analysts in the investment community believed that the capital inflows were likely to continue because they were based on local pro-market reforms. ${ }^{8}$

One study of early warning indicators among 105 countries over the period 197192, found that foreign variables were among those statistically significant in predicting the probability of a currency crash. Short-term world interest rates were important. ${ }^{9}$ A one percentage point increase in interest rates was estimated to raise the probability of a currency crash by about one percentage point per year. The combination of high indebtedness (debt/GDP ratio) and an increase in world interest rates was particularly likely to lead to trouble. (OECD output growth had an effect on the crash probability that was less clearly significant.) Similarly, Eichengreen and Rose (1998) found that foreign real interest rates were significant in predicting banking crises as well among emerging market countries.

Calvo, Leiderman and Reinhart (1993) -- two years before the Mexican peso crisis - warned that "The importance of external factors suggests that a reversal of those conditions may lead to a future capital outflow." The warning was little heeded at the time. But the prediction came true in 1994, when the Federal Reserve raised interest rates seven times, a total of 3 percentage points (starting Feb. 4, and counting the last one on Feb 1, 1995). Foreign purchases of peso assets came to a halt. The assassination of Mexican presidential candidate Luis Donaldo Colosio and a period of other political disturbances also began in early 1994, so it is difficult to disentangle the causes. Both sets of factors undoubtedly played a role, along with domestic macroeconomic policies. In the absence of domestic adjustment during the course of the year, reserves hemorrhaged in December, leading to the collapse of the peso. Regardless what one thinks of the deeper causes of the problem, or of the need for vigilance by the Fed on

\footnotetext{
${ }^{8}$ A summary of details regarding the data and statistical techniques used in these four studies appears in Frankel and Okongwu (1996). (That paper also presents more econometric evidence of a heavy influence of US interest rates on portfolio capital flows and local interest rates; these results go up to December 1994, and thus include the adverse effects of US interest rates in 1994 on the Mexican peso crisis.) For a more recent study that finds a significant role of US interest rates in determining capital flows to emerging markets, see Mody, Taylor and Kim (2001). They, like some of the other studies, find that the US real growth rate may be at least as important a determinant as US interest rates.

${ }^{9}$ Computed as an average of interest rates in six industrialized countries, with weights determined by shares in the debt of the developing country in question. Frankel and Rose (1996). Other variables were also statistically significant in predicting currency crises. Some of the most important concerned the composition of the preceding capital inflows, a topic relevant for the reform of the international financial system.
} 
inflation, the increases in U.S. interest rates were among the proximate causes of the Mexican crisis.

There are a number of channels whereby foreign interest rates affect emerging markets. First, high global real interest rates tend to depress, not just real economic activity in general, but the prices of the basic commodities produced by many developing countries in particular. Second, high interest rates directly raise debt service costs. Particularly where debt is short-term, or with floating interest rates tied to LIBOR or the US treasury bill rate, an increase in world interest rates translates immediately into a higher interest bill for debtor countries. Thus the ratio of debt service to exports suffers as a result both of an increase in the numerator and a decline in the denominator.

In recent years the emphasis has shifted from the ability of debtors to service bank loans out of export receipts -- or to roll them over -- to the ability of emerging markets to retain investor confidence and thereby attract enough new inflows to meet maturing bonds. High interest rates in industrialized countries make investments in emerging markets less attractive. At first, diminished capital inflows may show up as only a gradual loss of reserves. But in a speculative attack, the country loses the confidence of the international financial markets unless it raises interest rates sharply, and sometimes even if it does.

The new abundance of data on securities prices in emerging markets over the last 15 years makes it easier to examine statistically the sensitivity to financial conditions in the industrialized countries. An increase in the G-7 real interest rate (weighted average of the countries' lending rates, adjusted for one-year lagged inflation) has a negative effect on the composite index of emerging market equities. The effect of a one percentage-point increase in the real interest rate is an estimated $.17 \mathrm{drop}$ in the log composite index (17\%). The effect on Latin America considered alone is higher, an estimated .42 drop, and on Asia is lower, an estimated .11. ${ }^{10}$ An increase in the real US fed funds rate has an effect on emerging equity markets that is comparable in magnitude - greater in magnitude, in the case of Latin America -- than the effect on US equity markets. The EMBI Global, which tracks returns for US dollar-denominated debt instruments issued by emerging market sovereign and quasi-sovereign entities, also appears to fall as G-7 lending rates increase. A one percent increase in the G-7 real interest rate coincides with an estimated 34 percent decline in the EMBI.

\footnotetext{
${ }^{10}$ These effects at first appear significant statistically, but the significance levels drop sharply when correcting for high serial correlation. The equations were estimated from annual IFC Global data, complied by the Standard and Poor's Corporation, over the period 1984-1999.
} 
Table 2:

Sensitivity of Emerging Market Securities Prices and Growth to G-7 Interest Rates

\begin{tabular}{|c|l|l|l|}
\hline $\begin{array}{l}\text { IFC Global Index of equities } \\
\text { Regressed against the G-7 real lending rate }\end{array}$ & Coeff. & $\begin{array}{l}\text { Std. } \\
\text { Error }\end{array}$ & R-sqr. \\
\hline Composite & -0.17 & 0.02 & 0.28 \\
\hline Asia & -0.11 & 0.03 & 0.09 \\
\hline Europe, Middle East and Africa (EMEA) & 0.03 & 0.06 & 0.004 \\
\hline Latin America & -0.42 & 0.03 & 0.58 \\
\hline $\begin{array}{c}\text { IFC Global Index of equities } \\
\text { Regressed against the US real Federal funds rate }\end{array}$ & & \\
\hline Composite & -0.11 & 0.02 & 0.19 \\
\hline Asia & -0.07 & 0.02 & 0.08 \\
\hline Europe, Middle East and Africa (EMEA) & 0.15 & 0.05 & 0.15 \\
\hline Latin America & -0.29 & 0.02 & 0.50 \\
\hline $\begin{array}{c}\text { US Standard and Poor's 500 Index } \\
\text { Regressed against the US real Federal funds rate }\end{array}$ & -0.16 & 0.11 & 0.04 \\
\hline $\begin{array}{c}\text { Emerging Markets Bond Index (EMBI) Global } \\
\text { Composite regressed against G-7 real lending rate }\end{array}$ & -0.34 & 0.03 & 0.63 \\
\hline $\begin{array}{c}\text { EMBI Global Composite } \\
\text { Regressed against the US real Federal funds rate }\end{array}$ & -0.23 & 0.07 & 0.14 \\
\hline $\begin{array}{c}\text { Eeveloping country growth } \\
\text { Regressed against the G-7 real interest rate }\end{array}$ & & \\
\hline Market borrowers & -0.39 & 0.27 & 0.09 \\
\hline Africa & -0.35 & 0.19 & 0.14 \\
\hline Asia & -0.04 & 0.21 & 0.002 \\
\hline Middle East and Europe & -0.20 & 0.22 & 0.04 \\
\hline Western Hemisphere & -0.77 & 0.23 & 0.35 \\
\hline
\end{tabular}

IFCG from Standard and Poor's, EMBI from JPMorgan, and interest rates from the IMF (International Financial Statistics and World Economic Outlook). All interest rates are expressed in terms of real percentage points and all indexes are expressed in log form.

Time periods:

- $\quad$ Regressions with EMBI use monthly data from January 1995 to December 1999 (60 observations).

- $\quad$ Regressions with IFCG use monthly data from January 1985 to December 1999 (180 observations), except for regressions on EMEA which use monthly data from January 1996 to December 1999 (48 observations).

- $\quad$ Regressions with S\&P 500 use monthly data from January 1996 to December 1999.

- $\quad$ Regressions of developing country growth against G-7 growth use annual data from 1977 to 1999 (23 observations). 
Real interest rates may also have a negative effect on real growth rates in emerging markets. The effect is only statistically significant in the case of Western Hemisphere countries, however: an effect estimated at .77 percent in lost growth for every one percentage point increase in G-7 real interest rates.

There is much less reason to think that foreign interest rates played an important role in the arrival of the East Asian currency crisis in Thailand in July 1997 as compared to earlier crises. There had been a quarter-point increase in the federal funds rate on March 25 of 1997, ${ }^{11}$ and later the first hints of a possible end to the Bank of Japan's policy of low nominal interest rates. But these developments were relatively minor. ${ }^{12}$

The passing of the crises of 1997-98, on the other hand, can be associated with monetary easing in the industrialized countries. August 1998 saw a second round of crises, with the Russian devaluation and default, and subsequent widespread contagion, including trouble for the real in Brazil and trouble for LTCM in New York. The G-7 responded in a multi-faceted manner (to be discussed below). The most potent arrow in the G-7 quiver was interest rates. One view is that each country's central bank would have been reluctant to cut interest rates on its own, for fear of capital outflows and currency depreciation. U.S. leadership could signal the move to a new easier-money global equilibrium. President Clinton, in a speech on the emerging market crises at the Council on Foreign Relations in mid-October, said that the balance of risks in the global economy had shifted from inflation to deflation. ${ }^{13}$ The Federal Reserve Board subsequently voted to lower the fed funds rate three times in the Fall of 1998 (endSeptember, mid-October and mid-November). Virtually every major central bank in the world followed suit. Within a few months the financial crisis had passed. There can be little doubt that the monetary easing played an important role. (Admittedly it took longer for the real economies to recover, in many of the emerging markets.)

Indeed, it is possible that the monetary easing of late 1998 is the answer to a puzzle that the case of Brazil otherwise poses. The conventional wisdom to come out of the crises of 1994-98 was that the worse thing a country can do, once capital inflows turn to capital outflows, is to delay an inevitable devaluation. Vulnerable emerging markets must choose between rigid institutional fixes for the exchange rate, for those countries willing to give up monetary autonomy, or else increased flexibility. ${ }^{14}$ If they stubbornly cling to a peg or other exchange rate target until they have lost most of their reserves, the devaluation when it comes will be very costly, resulting in a loss of confidence and a severe recession. This is what happened to Mexico, Thailand and Korea. Brazil stalled throughout the second half of 1998, hoping that capital outflows would abate, and postponing the devaluation in precisely the way that the conventional wisdom warned against. Yet when the Brazilian devaluation materialized in January 1999, the feared

\footnotetext{
${ }^{11}$ A few observers, apparently including some at the New York Federal Reserve, have implicated the Fed's one quarter-point move (which could have been the beginning of a new trend, even though it turned out not to be), in the subsequent withdrawal of international investors from Thailand. (Woodward, 2000, p. 188).

${ }^{12}$ World interest rates do not figure prominently in the more recent statistical studies of crisis predictors, probably because they were not close to the scene of the crime in 1997 when it came time to round up the suspects. E.g., Goldstein, Kaminsky and Reinhart (2000).

${ }^{13}$ Waldman (2000, p. 231). This was the one time that the Administration came close to commenting on monetary policy.

${ }^{14}$ See the chapter by Sebastian Edwards for this conference.
} 
adverse effects did not. Brazil's growth increased in 1999 -- led by newly-competitive exports, as in the traditional textbook view, but in contradiction to the new conventional wisdom. Furthermore, unlike the contagions of the preceding two years, the Brazilian devaluation had no serious repercussions outside the region. Why the contrast with the preceding crises? There are a number of possible explanations, but one major factor was the easing of liquidity by the major central banks and the restoration of global confidence that had taken place over the intervening five months.

Between the spring of 1999 and the spring of 2000, the Federal Reserve once again raised interest rates, in response to fears of overheating in the US economy. Spreads on some emerging market debt, along with spreads on low-rated US corporate debt, subsequently rose to levels reminiscent of the Fall of 1998. This renewed flight of investors away from risk contributed to tremendous financial pressure on Argentina and Turkey in November 2000. It is possible that the movement in US interest rates again contributed to these events.

As with the preceding crises in other countries, macro policies in the industrialized countries were not the only, or even most important, cause of the problems in Argentina and Turkey. In Argentina an overvalued currency, together with fiscal imbalances and large domestic and external debt refinancing needs, made investors nervous about the economic prospects of the country. In Turkey, structural weaknesses and scandals in the banking system were particularly relevant. In both cases, the turmoil in the currency and domestic bond markets was controlled in late 2000 through a combination of a stronger program of policy adjustment joint with packages of exceptional financing from the IMF (activation of the Supplemental Reserve Facility) and other official creditors; but the peg in Turkey collapsed in February 2001.

\section{B. G-7 Exchange rates}

Regardless what choices they make for their own currencies, even if they opt for a fixed exchange rate, small countries can do nothing about variability in the exchange rates among the dollar, yen, euro, and other major currencies. To peg to one currency is to float against the others. At a minimum, this variability complicates their lives. But some observers would protest that this description understates the problem. They attribute crises in emerging markets, in part, to fluctuations in G-7 exchange rates, and propose international plans to stabilize them.

The strong appreciation of the dollar in the early 1980s raised the value of the debt obligations of Latin American countries, relative to their export proceeds. The destinations of the exports were more diversified geographically (especially in Europe) than were the origins of the loans, which were mostly denominated in dollars. Thus the dollar appreciation was another of the contributing factors that precipitated the debt crisis.

\section{I.B.1. Did a rise in the yen/dollar rate cause the East Asia crisis?}

Standard accounts of the origins of the East Asia crises that began in mid-1997 also feature prominently the 40 appreciation of the dollar against the yen over the 
preceding two years. ${ }^{15}$ The East Asian countries are said to have lost international competitiveness because they were pegged to the dollar, which led to large current account deficits, loss of reserves, and ultimately the crises.

This argument is in some ways overstated. In the first place, the appreciation of the dollar against the yen was only a reversal of a sharp depreciation of the dollar that had preceded it in the early 1990s. ${ }^{16}$ In the second place, though the competitiveness effects were real enough, there was also a debt denomination effect that could go the other way. Not all foreign debt is denominated in dollars. The use of the yen in Asian finance increased sharply in the 1980s, and was widely heralded at the time. The southeast Asian countries, in particular, doubled the share of their debt denominated in yen from 1980 to 1987, surpassing the share denominated in dollars. For this reason, when Southeast Asians in the late 1980s pleaded for a reduction in yen/dollar volatility, citing fears of severe financial stress, they were worried about appreciation of the yen, not depreciation! $!^{17}$

Admittedly, the currency denomination of Asian debt reversed to some extent in the 1990s. By 1996, the dollar share had reached $41.5 \%$ and the yen share had declined to $24.0 \%$, for the region overall. But the situation varies substantially from country to country. Toward one end of the spectrum, two of the three crisis countries, Thailand and Indonesia, still had more yen debt in 1996 than dollar debt. For Thailand and the Philippines, the importance of the Japanese market in exports was well below the importance of the yen in their debt. For Indonesia, the debt shares corresponded roughly to the trade shares. Toward the other end of the spectrum, Malaysia and, especially, China, had dollar debt shares that were higher than their yen debt shares, and higher than the relative importance of the dollar area (taken to be the Western Hemisphere) in their exports. So these may be the countries that had the most to lose from yen depreciation. This may help explain why China opposed further depreciation of the yen against the dollar in June 1998. (A desire to placate China was reported to be the motive behind the yen purchases, the first time the Clinton Administration had intervened to resist dollar strength. But other reasons were important as well.)

As recently as the mid-1990s, fears of the consequences in Asia of a yen appreciation were associated with the yen-carry trade. When Japanese interest rates fell almost to zero, speculators began borrowing heavily in yen and investing the proceeds in dollar-denominated securities that paid higher interest rates, the practice known as yencarry trade. The difference in interest rates is pure profit if the exchange rate remains unchanged, but some were concerned that Asian speculators were underestimating the dangers of future yen appreciation, which could impose huge losses if it occurred. It is

\footnotetext{
$15120 / 85=1.41$.

16 The yen/dollar rate, which peaked near 147 in 1998, had also been at that level in 1990, and far higher than that before 1986 .

${ }^{17}$ It should also be noted that these figures apply only to long-term debt. Figures on the currency denomination of short-term loans are not available for all countries, but they were probably more often dollar-denominated than was long-term debt. (For Korea, short-term debt denominated in dollars represented $91 \%$ of the $\$ 19.9$ billion total, yen debt $7 \%$, and DM debt $1 \%$. The data include debt for all banks/countries that participated in the January 1998 rollover agreement.) It should also be noted that a comparison of debt shares and export shares tells the direction of effect on the debt/export ratio only if export quantities are fixed in terms of the partner's currency. It ignores, for example, competition with Japanese producers in other markets.
} 
ironic that during the two years leading up to the Asia crisis, the yen/dollar movement was in the opposite direction, and the yen carry trade was temporarily very profitable. ${ }^{18}$

To summarize the point, the depreciation of the yen between 1995 and 1997 helped the Southeast Asian debtors on the debt side, by reducing debt service costs and improving their balance sheet, even while it hurt them on the trade side. If the debt service ratio is a relevant indicator, then the depreciation of the yen against the dollar was actually good for countries like Thailand, where the share of debt denominated in yen exceeded the share of exports going to Japan, while bad for countries like China, where the reverse was true. We emphasize the implications for yen-denominated debt only because it has been completely neglected in most recent commentary. ${ }^{19}$

One interpretation is that large swings of the yen/dollar rate in either direction generate stress in the region, that volatility per se is the problem. If exchange rates among the major industrialized countries were stabilized, it would no doubt simplify the lives of everyone else. The key question then becomes whether this stabilization can be accomplished in practice, or at what sacrifice.

\section{I.B.2. The proposal for a $G$-3 target zone}

Such commentators as Bergsten, Williamson, and Volcker have urged the G3 countries to stabilize exchange rates, for example, through a target zone arrangement. One of their arguments is precisely that excessive exchange rate volatility among the dollar, yen and euro play a role in emerging market crises. ${ }^{20}$ Most economists, however, believe that exchange rates reflect monetary conditions in the corresponding countries and other economic fundamentals such as productivity, that the G3 countries have no means for stabilizing their exchange rates other than devoting monetary policy to the task, and that they neither should nor will subordinate domestic priorities to such international goals. $^{21}$

We believe that the view that all exchange rate fluctuations are attributable to monetary policy and other economic fundamentals is too simple. Sometimes the exchange rate moves for reasons unrelated to fundamentals, and sometimes governments can combat such moves by public statements or intervention in the foreign exchange market, even if these actions don't change monetary policy. ${ }^{22}$ Intervention in support of the dollar in mid-1995 was instrumental in reversing the preceding depreciation of the dollar, and intervention in support of the yen in mid-1998 may also have played a role in reversing the depreciation of the yen.

\footnotetext{
${ }^{18}$ Such fears indeed became relevant in the fall of 1998, when the yen appreciated sharply.

${ }^{19}$ The Frankel-Rose (1996) study looked for evidence of the debt exposure effects. The question was whether the probability of a currency crash increases in a country when there is an appreciation of the major currencies in which a high proportion of that country's debt is denominated. Even though other measures of the composition of capital inflows or external conditions showed up as significant indicators (e.g., the share of short-term debt and foreign interest rates), this measure of currency composition and movements in G-3 exchange rates did not show up with the sign expected. Perhaps the trade composition channel on average outweighs the debt composition channel.

${ }^{20}$ See, for example, the dissenting statement "On Target Zones for the G-3 Currencies," by Paul Allaire, C.F. Bergsten, and others including George Soros and Paul Volcker, in Council on Foreign Relations (1999), pp. 125-129. They believe there can be no serious reform of the architecture regarding emerging markets without a plan to stabilize the dollar, yen and euro.

${ }^{21}$ E.g., Clarida (1999).

${ }^{22}$ Dominguez and Frankel (1993).
} 
Nevertheless, the majority's policy conclusion stands. If the G-3 or G-7 were to proclaim an explicit target zone for the major currencies, it would not be long before speculators were testing the limits, a challenge in which they would eventually be successful. We do not view a target zone among the G3 currencies as a practical reform to help avert crises in emerging markets.

\section{Industrial Country Trade Policies}

International trade is an important engine of economic development even in the best of times. ${ }^{23}$ When a developing country undergoes a balance of payments crisis, the ability to increase exports rapidly (or more generally to increase production of internationally traded goods) is critical to its resolution. For many of the recovering victims of recent emerging market crises, an improvement of the trade balance led the stabilization of confidence on the part of international investors. These countries succeeded in switching from large deficits to surplus in the span of a couple of months. Unfortunately, this initial "improvement" in the trade balance usually takes the form of a sharp drop in imports due to domestic recession. It takes longer before the devaluations have the intended effect of promoting exports. Only over the subsequent few years does growth in exports lead the recovery of economic activity.

In the past, the highest barriers to international trade have been those put in place by the developing countries themselves. But most of these countries, at least most who qualify as emerging markets, went a long way in the 1990s toward reducing trade barriers. Industrialized countries retain substantial barriers to exports from developing countries, and there is little evidence of a downward trend. True, the rich countries in the Uruguay Round of multilateral negotiations to liberalize trade promised to phase out over time their quotas on apparel and textiles, two of the most important sectors for developing countries, and to end the previous exemption of agriculture from multilateral negotiations. But the phasing out has yet to begin, and there is even less sign of any intention to liberalize with respect to those agricultural products such as sugar and rice which are of particular interest to developing countries.

In fact, many rich-country politicians, in the wake of both the 1982 and 1997 crises, responded to increases in their constituents' purchases from developing countries by supporting new protection of domestic markets. They either did not realize or did not care that shutting off these exports was inconsistent with calls on emerging market countries to obey the rules of the marketplace and to generate the foreign exchange needed to service their debts. Barriers to the export of steel from Brazil, Korea, and Russia were perhaps the strongest examples.

What are the chances that a future WTO Round will address the export interests of the developing countries? Even though decisions in the GATT and WTO are technically made by consensus, with each country having an equal vote, it is inevitable that some players in practice count far more than others. The pattern in past GATT rounds has been that cut-and-thrust exchange between the United States and Europe has

${ }^{23}$ Econometric evidence and further references are available in Frankel and Romer (1999). 
dominated the negotiations, and when those two powers have come to some agreement, the rest of the world generally falls into line. Other countries have had little influence over the agenda. Little vote was given to the developing countries, largely because they had little in the way of lucrative concessions to offer the rich countries.

Increasingly, however, the developing countries are important players, at least collectively. Asia and Latin America now constitute major markets. Under the new rules agreed in the Uruguay Round, they like other WTO members are generally no longer able to opt out of aspects of an agreement, ${ }^{24}$ or to block decisions by panels under the dispute settlement mechanism. Furthermore, in the Uruguay Round developing countries were asked in the area of Intellectual Property Rights to put energy into enforcement of a set of rules that, whatever their economic justification, benefit rich-country corporations and not them. For all these reasons, in the next round of WTO negotiations their interests will have to be taken into account. In addition to liberalization of textiles trade, this would also mean protection against arbitrary anti-dumping measures, if the United States would agree (and liberalization in agriculture, if Europe would agree). If a new round has nothing to offer the developing countries, they might this time try to block it.

We have explained the role of textiles and apparel, the first rung of manufacturing exports for poor countries seeking to climb the ladder of development. Rich countries agreed in 1995, under the Uruguay Round, to phase out over the next ten years the quotas that under the Multi Fiber Agreement (MFA) have long kept the textile sector highly protected. An acceleration of the schedule is the simplest concession to offer the poor countries in exchange for the many demands being placed on them. But little liberalization has occurred to date. The difficult time the US Administration had in 19981999 in convincing the Congress to support the elimination of barriers to apparel exports even from Africa and the Caribbean is revealing. China's accession to the WTO alarms some with the prospect of a huge increase in the global supply of inexpensive textiles and apparel. There are grounds for skepticism, given domestic politics in the United States and other rich countries, regarding whether the MFA phase-out that was promised in 1995 will actually happen. If rich countries fail fully to deliver on this promise, it is hard to see what incentive developing countries have to go along with a new Round, or even to carry out their Uruguay Round commitments in the area of Intellectual Property Rights. ${ }^{25}$

Antidumping (AD) measures are on the upswing. In 1999, 328 AD cases were launched, up 41 percent from 1998, and more than double the rate in 1995 . $^{26}$ The name "antidumping" makes the measure sound like it has something to do with antitrust enforcement against predatory pricing; thus it gives the press and public the impression that these measures are a tool to combat trade distortions and increase competition. But they have nothing to do with predatory pricing, they suppress competition rather than defend it, and they are among the costliest of trade barriers. ${ }^{27}$

\footnotetext{
${ }^{24}$ Bhagwati (1998). The requirement that WTO members must adhere to all negotiated obligations as a "single undertaking" still has exceptions for the poorest developing countries. Also, two areas, government procurement and civil aviation, remain under "plurilateral accords" of the WTO. Schott (1998, p.3).

25 Wang and Winters (2000), and Subramanian (1999).

${ }^{26}$ The Economist, April 22, 2000.

27 The enactment of antidumping duties means import quantities on average fall by almost 70 percent and import prices rise by more than 30 percent -- Prusa (2000).
} 
The use of AD measures increased rapidly in the United States in the 1980s and 1990s, because firms hit by increased imports found it much easier to gain protection under the antidumping laws than under the safeguard laws. Their use has subsequently increased rapidly in other countries as they emulate and retaliate against the United States. An attempt to rein in the indiscriminate use of antidumping would rank near the top of the economist's wish-list of priorities for the next round of multilateral negotiations. (It could be coupled with some steps toward a multilateral competition policy, to reassure those who are under the illusion that the AD laws have some procompetition value.) Unfortunately, the United States is unlikely to agree to the inclusion of this issue.

Nothing requires waiting for a new WTO round, to reduce trade barriers against emerging markets. In the aftermath of the 1997-98 crises, the major industrialized countries could have committed collectively to keep their markets open to exports from other countries. But even an initiative to commit the rich countries to end quotas and duties on their imports from the poorest countries, at the Fund-Bank meetings in the Spring of 2000, ran into the inevitable political roadblocks. ${ }^{28}$

To recapitulate the conclusions of Part I, movements among the industrialized countries in interest rates and, to a lesser extent, exchange rates, can have important influences on emerging markets. Inflationary monetary policies among industrialized countries might temporarily help emerging markets, but would also do substantial damage to the industrialized countries. Sustaining their own growth and keeping their trade barriers low may be the most important things that industrialized countries can do to maximize growth in emerging markets and minimize the frequency and severity of crises. At the end of the day, providing open markets for goods and services is probably more important than all the institutional reforms that have been proposed regarding the financial architecture.

\section{Crisis Management}

There is a vast array of organizations and venues where national representatives deliberate over measures that affect emerging markets, whether the measures are in the category of short-term macroeconomic policy coordination or long-term reform of the international financial architecture to reduce the frequency of future crises and resolve more efficiently those crises that do occur. When a crisis breaks out, these mechanisms become particularly important as a mode of crisis management, that is, as a means to minimize adverse effects.

\section{A. Modalities of Coordination}

The governments of the industrialized countries dominate the discussions in these meetings. One defense against wider inclusion is that speed and decisiveness are important in crisis management, which requires a small number of participants. Moreover, groupings of small countries receive a voice through proportionate representation, as is the case on the IMF Board of Executive Directors (with votes

\footnotetext{
${ }^{28}$ E.g., "Spring Meetings Fail to Burst into Blossom," Financial Times, April 19, 2000.
} 
roughly proportionate to economic importance). One rationale for participation by the IMF Managing Director in G7 Finance Ministers' meetings is as a representative of the smaller countries. (The Russian President is now included in G-8 Summit meetings; but the country is not invited to participate in G-7 meetings on financial topics.)

Furthermore, some emerging market countries are large. By 1996, China and Brazil had in economic size surpassed Canada, the seventh largest country in the G-7, even when their GDPs are valued at current exchange rates. In addition, India, Mexico and Indonesia had done so if one evaluates GDPs by Purchasing Power Parity. ${ }^{29}$ Switzerland, Belgium and Sweden are in the G-10, but by 1996 China, Brazil, Korea, Russia, India, Argentina and Mexico had passed Sweden, even at current exchange rates (as had many others, if one evaluates GDPs at PPP rates). After the crises of 1997-99, the emerging markets all slipped in the rankings. In 1999 only China remained ahead of Canada, by the PPP measure; Brazil, Mexico, India, Korea, Taiwan and Argentina remained larger than the smaller members of the G-10.

Thus, the fact that the G-7 (United States, Japan, Germany, France, United Kingdom Italy and Canada) and G-10 economies are overall larger than the developing countries does not explain the membership in the $\mathrm{G} 7$ or $\mathrm{G} 10^{30}$. Another relevant principle that explains these power relationships is that creditors generally have influence over debtors. ${ }^{31}$ While the United States (and Italy) are net debtors internationally in the context of crises they are net lenders to crisis countries and to the international financial institutions. Perhaps the most succinct description of the membership of the G-7 is that it represents the victors in the Cold War, much as the membership of the UN Security Council was chosen to represent the victors of World War II. Moreover, the growing economic importance of systemically important emerging market economies is behind the recent drive to create international groupings, such as the G-20 (to be discussed below), that include these countries along with the advanced industrialized countries.

\section{II.A.1. G-7 Finance Ministers and Deputies}

The G-7 Finance Ministers, their deputies (D's) and deputies' deputies (DD's) play a crucial and central role in crisis management. This role takes three central forms:

a) Consultations and cooperation during crises of systemically important countries to resolve such crises (Mexico, Thailand, Korea, Indonesia, Russia, Brazil)

b) Joint work to develop G-7 policies and doctrine on how to prevent and resolve financial crises (as in the work on the reform of the international financial architecture)

\footnotetext{
${ }^{29}$ National incomes are properly evaluated at purchasing power parity rates if one is interested in the real incomes of the population. For purposes of evaluating weight in international power relationships and responsibilities, it is more appropriate to evaluate at actual exchange rates. For example, one might care how many F-16s a country can buy, how much money it can offer a small island nation for the right to put a naval base there, or how much it can contribute to a multilateral peacekeeping operation, famine relief, debt forgiveness, or the New Arrangements to Borrow. In each case, current exchange rates are the right measure, as variable as they are.

${ }^{30}$ This group has actually 11 members: the G7 plus the Netherlands, Belgium, Sweden, and Switzerland.

${ }^{31}$ This truism is somewhat at odds with another favorite and wise aphorism: "If you owe your banker a million dollars, you have a problem. If you owe your banker a billion dollars, he has a problem."
} 
c) Crisis management for non-systemic countries requiring external debt rescheduling/restructuring (Pakistan, Ukraine, Ecuador, Romania) and formulation of official doctrine on private sector involvement in crisis resolution.

Crisis management and resolution as well as formulation of policies regarding PSI (private sector involvement) involves a number of other institutions, namely the IMF, the Paris Club, the BIS and G-10 central bank governors, national security agencies and heads of state and, more recently in a more limited consultative forum for discussing general PSI policies, the G-20 group. The role of these other players will be discussed below, after the G-7.

There are a variety of views among the G-7 on how to deal with these three sets of issues but the G-7 have been able to reach a solid consensus on most issues. Indeed the work on crisis management and architecture reform has been very cooperative. On the question how to deal with systemic liquidity cases, Europeans have been slightly more wary than the U.S. of providing large packages of official money out of concerns about moral hazard. Some Europeans have also correspondingly been somewhat more hawkish in support of more coercive ways to involve the private sector in crisis resolution, including a stronger sympathy for the idea of debt standstills. The U.S. has stressed the importance of maintaining some degree of flexibility to address each case on its own merits rather than relying on more rigid or formal rules, including using large official packages when appropriate. The U.S. has shown greater support for the idea of corner solutions in exchange rate regime (either a firm fixed or flexible one, as opposed to intermediate regimes) than the European and the Japanese, and less sympathy for some suggestions to restrict international capital flows (both inflows and outflows). Some Europeans and Japanese are also more sympathetic towards ideas regarding direct rather than indirect regulation of highly leveraged institutions such as hedge funds in the context of the work of the Financial Stability Forum. There has also been a broad related discussion among the G-7 on how to reform the IMF. In spite of the different nuances and differences, the G-7 have been able to reach a significant and constructive consensus about the various elements of architecture reform, including private sector involvement, as shown by the G7 Koln summit report and the Fukuoka summit report as well as other G7 Finance Ministers reports and communiqués at the IMF/WB meetings.

The G-7 dialogue has included issues such as: how to reform IMF facilities with Europeans being more sympathetic to the Extended Fund Facility (EFF) and the U.S. wanting to provide a greater role to the Contingent Credit Line (CCL), how much emphasis to give in country programs to traditional macroeconomic policies relative to structural ones, how to reform the governance structure of the IMF (with European pushing for turning the former Interim Committee into a stronger and more powerful executive body; and the eventual compromise turned it into the International Financial and Monetary Committee - IMFC); and how to reform the current country quotas (as, according to some criteria, the European countries are currently overrepresented and emerging market economies are underrepresented $)^{32}$. Again, this dialogue has been constructive and led to the development of a consensus as represented by the G7 April

\footnotetext{
${ }^{32}$ See IMF (2000c) for the report of the official "Cooper Commission" on how to reform the country quotas.
} 
2000 Finance Ministers Communique at the time of the IMF/WB annual meetings. At the annual IMF/WB meetings in Prague in September, 2000, agreement was reached on how to operationalize the reform of IMF lending facilities and broader reform of the $\mathrm{IMF}^{33}$.

Developing countries believe that they should be better represented in the decisions that affect them. The issue of the representation of significant emerging market economies in international bodies has emerged not only in the context of the discussion about IMF quotas but also in the U.S. position, viewed with some concern by some European G-7 countries, that the views of such emerging markets should be more broadly represented in global affairs. The Europeans know that any such shift in power will come largely or entirely at their expense. The U.S. push to involve emerging market countries began with a proposal by President Clinton in November 1997, at the Vancouver Leaders Summit of the Asia-Pacific Cooperation forum. It took the form of support for the inclusion of significant emerging market governments in the ensuing G-22 and G-33 process, that led to three early reports in late 1998 on international architecture reform; and later the creation of the G-20 group as a regular forum of dialogue among advanced industrial economies and a group of systemically significant emerging markets. The transformation of the Interim Committee into the IMFC balanced some European concerns about the creation of new groups such as the G-20.

\section{II.A.2. Coordination among Central Bankers and the BIS}

G-10 Central bankers and the BIS have also been involved in crisis management and resolution. A particularly significant role in crisis response and management has been played by the U.S. Fed given the lead role of the U.S. in international financial policies. The role of G-10 central banks has been more prominent in the large systemic liquidity cases rather than the smaller non-systemic countries cases. In the former cases (Mexico, Thailand, Indonesia, Korea, Russia, Brazil) G-10 central banks have been directly involved in the formulation of official policy: i.e., consultations on how to deal with systemic countries, on the size of official rescue packages and involvement in lining-up second line of defense financial support.

G-7 Finance Ministries have been most directly in charge of the design of official G-7 policy regarding the reform of the international financial architecture (the Koln and Fukuoka summit reports) but central banks have been widely consulted in this process.

G-10 central banks direct involvement in the formulation of official policy for private sector involvement in crisis resolution has been more limited (relative to that of Treasuries and Finance Ministries) even if G-10 central banks have run some seminars and activities in the debate on PSI. Their involvement in non-systemic debt restructuring cases has been also more consultative than direct crisis management even if some central banks (the U.S. Fed and the regional New York Fed) play a larger role in such cases as well.

G-10 central banks and the BIS play a larger role in addressing global systemic risk issues and in questions of international financial regulation (the Financial Stability Forum work). The Fed (both the Board and the New York Fed) was deeply involved in the management of the LTCM crisis. The Basle Eurocurrency Committee (now the CGFS or Committee on Global Financial Stability) has been involved in discussing, managing

\footnotetext{
${ }^{33}$ The details of this agreement are described in section V.D below.
} 
the response and formulation of policies to address episodes of global financial turmoil, global liquidity shocks and systemic financial crises.

G-10 central banks have also been deeply involved in the work of the Financial Stability Forum and its formulation of recommendations on highly leveraged institutions, short-term capital flows, offshore financial centers, implementation of codes and standards and reform of deposit insurance.

Also, the formulation of monetary policy by G-10 central banks has been affected by episodes of systemic crises. The reductions of interest rates by the Fed and many other central banks in the fall of 1998 (following the Russian default, the LTCM crisis, the seizure of global liquidity and the spillover of financial turmoil from emerging markets to U.S. and other G-7 capital markets) were not coordinated but were successful in stemming the risk of a global financial meltdown.

Also, the work on the reform of the Basle Accord (the BIS capital standards) has seen a central role for the central banks (and other institutions) that supervise and regulate the banking and financial system.

\section{II.A.3. Paris Club}

The Paris Club (PC) is a major forum for crisis management and resolution, as it is in charge (in consultation with the IMF) of the rescheduling of official bilateral credits to emerging markets. The Paris Club has become the lightning rod of the many complaints of the private sector against the official policy for private sector involvement (PSI) in crisis resolution (as emerged from recent policy debates and private financial sector views on official PSI policy in general and bonded debt restructuring in Pakistan, Ukraine, Russia, Ecuador and Nigeria in the specific). The Club has been accused of being a secretive organization, arbitrary and unfair, in its decisions; forcing the private sector to be the residual claimant (deciding first how much the official creditors are paid in cash when there are external financing gaps and let the residual be paid to private creditors); expecting private debt reduction when it does not provide any itself; lacking transparency, predictability and openness; unwilling to engage the private sector in negotiations and dialogue; politically biased in its decisions; and imposing comparability (restructuring of private claims on terms comparable to restructuring of official claims) while not accepting reverse comparability (restructuring of official claims on terms comparable to that of private claims in cases -- like Russia - when private claims are restructured before Paris Club ones).

Many of these critiques suggest a significant misunderstanding in the financial community of the role and functions of the Paris Club.

The first misconception about the Paris Club is the belief that its claims are senior to those of the private sector. While official bilateral claims are perceived to have legal seniority over private ones, the reality of international finance is that Paris Club claims are always effectively junior to private ones. When a country experiences debt-servicing difficulties, the first payments that are suspended are those to Paris Club creditors. Debtors know that going into arrears to PC creditors has little consequence (as such claims are eventually rescheduled) while non-payment to private creditors has consequences (formal default, acceleration, litigation risk, et cetera). Thus debtors are most eager to stop paying official bilateral creditors well before they stop paying private creditors. Indeed, strategic non-payment to PC has long been used by debtors as a way to 
continue paying in full and on time to private creditors. The accumulation of arrears to PC creditors is a systematic and endemic phenomenon that has allowed the continued payments to private claims; for example, Nigeria accumulated over $\$ 23$ billion of arrears to PC and has so far paid in full its private debts. This is a distorted system of incentives: no private creditors would be willing to provide credits to a sovereign at the terms, risk features and spreads provided by official bilateral creditors. Indeed, the fact that countries were still able to have market access in spite of rising PC arrears (as in the case of Ecuador issuance of Eurobonds in the mid 1990s) implied that investors believed that the financing burden would be shifted to the official creditors and they would not be "bailed in". But recent applications of the PSI framework (discussed below) have changed this perception: investors do now realize that countries with significant PC arrears are more likely to be involved in PSI, when private claims are material.

Second, PC claims not only are the first to go into arrears but they are immune from litigation risk; they are not subject to rollover risk as they effectively have a rollover option given to the debtor as the latter can always stop paying with little consequence; and they are not subject to liquidity risk driven by any panic of creditors withdrawing lines of credit. Also, such claims are restructured at terms that are often quite generous and at interest rates that do not truly reflect repayment risk. Note that if the market had to provide similar claims not subject to rollover, liquidity, litigation risk, the pricing of such debt (in terms of spread over risk-free assets) would be most expensive. So, the treatment of PC claims is more beneficial in most dimensions for the debtor than that of private claims.

Third, the Paris Club does not systematically provide debt reduction apart from cases in which the country qualifies for debt reduction such as qualification under the Highly Indebted Poor Countries initiative -- HIPC -- or other criteria. However, the terms of $\mathrm{PC}$ rescheduling are generous and imply some significant effective reduction in the Net Present Value (NPV) of such claims. In fact, the PC fiction of rolling over claims at the contractual original low interest rate and discounting the present value of restructured claims with a discount rate equal to this rollover rate allows the accounting fiction of maintaining NPV neutrality. The use of a more economically appropriate discount rate reflective of the actual expected repayment probability would imply some significant NPV reduction. While finding the appropriate discount rate for PC claims is not easy (as it is likely to be smaller than market rates but much higher than the officially used rate), the terms of PC claims and their restructuring (systematic arrears; no rollover, liquidity and litigation risk; generous restructurings with long grace periods and low interest rates; and eventual debt writedowns for some qualifying debtors) suggest that, in most cases, PC claims are effectively reduced rather than just restructured even if they are formally not subject to face value reduction. Thus, arguments that PC restructurings are unfair to private creditors when, as in the case of Ecuador, the private sector is asked to provide for debt reduction while the official sector is not, miss the point: PC restructuring are usually not NPV neutral. Thus, PC restructuring can be "comparable" to private claims debt reduction even when formal face value reduction is not immediately provided by PC creditors.

Fourth, the rules followed by the Paris Club are quite clear and the criteria, amounts and terms of restructurings quite forecastable, given the track record and procedures of the Paris Club (normal terms for middle income countries, Houston terms 
for poor ones, HIPC terms for those who qualify for HIPC, et cetera). Thus, the private sector is normally able to infer how much finance will be provided by the Paris Club creditors. The current process is not much different from that in the 1980s where PC restructurings were followed by London Club restructurings on "comparable" terms. (The London Club represents private banking creditors in the same way that the Paris Club represents government creditors.) The main difference is that now bonded debt may also be subject to comparability as it is no longer "de minimis" -- a consequence of the rising importance of securities markets in international capital flows that were once dominated by bank loans.

Fifth, the Paris Club could do better in terms of providing more information and transparency about its activities. But there are limits to what can be done, as the PC is not a structured formal organization but rather a hoc group of rotating creditors. In this sense, there is not an official PC view, spokesperson or common view; any external view would have to be cleared by all relevant creditors. However, the PC has recently made some progress in this front by committing to the creation of a web site that will provide information to markets and investors about its activities, rules and procedures.

Sixth, the idea that "reverse comparability" would be used in deciding how to fill a financing gap would create many problems. 1) Some clear burden-slicing rules such as a proportionality principle (whenever there are external financing gaps make cash payments on debt servicing due and restructure private and official claims according to the proportion of private and public claims coming to maturity or payments coming due) would provide a simpler, more predictable and, some would say, fair distribution of the burden than a formal negotiating process; 2) the nature, motivation and terms of the official bilateral claims are very different from those of the private claims; thus attempts to negotiate a "fair" distribution of the burden are burdensome and add to uncertainty rather than reducing it; 3 ) the current structure of the distribution of the financing burden (country adjustment first, senior status for new IFI money, more junior status for PC claims with clear and established rules for their restructurings, residual financing by private sector) provides a clear and mostly predictable system of adjustment and financing. It is not clear that a system where the financing burden on the private sector is negotiated would improve on this system.

Seventh, while private sector participants concentrate on the contribution of the PC creditors, it is clear that the effective contribution of the official sector to PSI also includes the new money provided by the multilateral creditors; this contribution is often significant and may be even larger than that of bilateral creditors. Conceptually, the larger the combined support of official creditors (both bilateral and multilateral), the smaller is the amount of private claims that are subject to PSI. And, indeed, often the private sector response to requests for PSI has been to ask the official creditors as a whole to fill in the entire financing gaps, to avoid non-payment on private claims so as to shift the full adjustment burden on the official sector.

Eight, some confusion derives from the fact that the PC does flow restructurings while the private sector does stock restructuring. The origin of this distinction goes back to the 1980s. The Paris Club would restructure all the claims (including arrears) that came due during the consolidation period; thus, only current payment flows are restructured rather than the total stock of outstanding debt to official creditors. This also means that repeated flows restructurings of PC claims are necessary, as the stock of debt 
is not dealt with once and for all but only the consolidation period flow payments. The London Club instead would take a stock approach, given the nature of the claims rescheduled, i.e. syndicated bank loans, and restructured the entire stock of claims that were due in the consolidation period, both interest and full principal. Once the doctrine of PSI was applied to bonds starting in 1999, it was logical to take a stock approach for the bonded debt. While restructuring only payments due in the consolidation period could be technically feasible, dealing with the full stock makes more sense as bond restructurings require bond exchanges of the full stock of debt. It would be extremely cumbersome and inefficient to have only flow restructurings of bonded debt and do bond exchanges over and over again every few years. Thus, the rationale of dealing with the stock of bonded debt once and for all and restructuring it according to terms that ensure medium- to longterm viability of the debtor.

Ninth, formal negotiations of the private sector with the Paris Club to discuss the "slicing of the pie" are not likely to be productive for several reasons. First, PC rules for restructuring vs. upfront cash payments are clear and known for a long time. Second, negotiations may lead to endless delays that may be beneficial to none. Third, the current system is effectively close to the proportionality distribution of the debt burden described above. Also, once the upfront cash payments distribution has been figured out, there is little to negotiate as the constraint of medium term debt sustainability and standard PC rules for the terms of the restructuring of the remaining liabilities determine clear parameters of what is comparable and what is sustainable.

Finally, while the original PC claims against a sovereign may be financing projects that are not motivated on strict commercial terms, this does not mean that all PC loans are strictly "political". If there is a political element in such loans, the effectively subsidized terms of the loans (that is, interest rates that are sub-market, adjusted for repayment risk) also price that subsidy transfer. Also, some of the financed projects are either formally or informally of a tied-aid nature that provide benefits to private sector firms of the creditors country. Thus, the private sector often significantly benefits from such "politically" motivated loans.

\section{II.A.4. Other government agencies and heads of state}

Other government agencies, such as national security agencies, ministries of foreign affairs and defense ministries, as well as heads of government, are also involved in crisis management in important countries even if Finance/Treasury Ministries have had a central role. Quite naturally, geopolitical, strategic and military considerations play some role in deciding the response to crises. A naïve view would argue that the introduction of non-economic considerations in crisis response represents an interference with sound economic judgment. But decisions about international financial policy are inherently political in the positive political-economy sense of the word. Countries are "of systemic importance" not only because their size implies systemic contagion effects to other economies in the region or around the world. They are also systemic for geostrategic reasons. For example, Indonesia is the largest Muslim country in the world; its stability has economic and strategic implications for the entire Asian region. Russia is also systemically important, for both the U.S. and Europe, in part because of geostrategic reasons. (Its GDP is smaller than that of the Netherlands). To consider these political factors need not imply compromising sound economic judgment on whether support should be given and how much support. It means instead that the policy process 
considers the political economy of stabilization and reform: how much a country can adjust given its political constraints, and the strategic implication of providing or nor providing financial support. ${ }^{34}$ The concern that consideration of extra-economic issues may lead to moral hazard (expectations of bailout of systemically important countries) has a valid basis. But rarely do such considerations dominate more narrow economic criteria for supporting adjustment in a crisis country. In the dialogue between finance ministries and agencies for national security, the former usually play the role of guardians of fiscal and monetary orthodoxy and stress the importance of sound politically unbiased decisions on whom and by how much to support financially. The latter are, obviously, more concerned about the strategic effects of letting a systemically important country go. Sometimes the Finance Ministries explain to the others that there may be no way the West can help a crisis victim that isn't willing or able to help itself, no matter how politically sensitive the country is.

National security agencies and foreign affairs ministries are also quite involved in consultations with Finance Ministries on the proper response to crises in nonsystemically important countries. Some of them (Pakistan, Ukraine, Ecuador, Romania, Nigeria) have political importance that goes beyond their economic size. Generally, Finance Ministries are more "hawkish" (less willing to provide support to poorly managed economies where there is a poor track record of commitment to stabilization and reform) while other agencies, ministries and departments are generally more "dovish".

Heads of state get involved in crisis management in large systemic cases (Mexico, Thailand, Indonesia, Korea, Russia and Brazil), during episodes of severe global financial turmoil (as in the fall of 1998) and as a part of the G-7 summitry. The speech at the Council on Foreign Relations by U.S. president Clinton in the fall of 1998 showed - at the highest level - the concern about the risks of a global financial meltdown and engagement in trying to design policy responses to such a risk. Progress on architecture reform has been achieved in preparation for various G-7 heads of state summits (Halifax, Kohln, Okinawa). Even the formation of the G-20 was a partial response to heads of state interest in getting involved in a broad dialogue on global issues, though the eventual G20 group was centered around Finance Ministries rather than heads of state.

\section{B. The Role of the G-3}

The G-7 club is already sufficiently exclusive to expose it to charges of elitism. But even this exclusive club of richest countries can be effectively reduced to the G3 : the United States, the EU, and Japan. Furthermore, it is commonly believed that the United States has disproportionate power in the deliberations of the G-7 and IMF. The

\footnotetext{
${ }^{34}$ In some sense, some critics (Wyplosz, Giavazzi et al., 1999) of the IMF as not being "independent" of its leading members miss the point. In a positive sense, the IMF is a "political" institution that is accountable to its shareholders while at the same time maintaining its standards, following its mandate and rigorously applying its articles of agreement. As in any other efficient principal-agent relation and corporate governance issue, the appropriate balance between goals and objectives of major shareholders (G-7 and other industrial countries) and minority shareholders (emerging market economies) has to be found. But independence, by itself, has little meaning.
} 
complaint that the global system is essentially run by the G-1 is well represented by the following quote.

“...[C]ertain national governments -- and the United States in particular -exercise a disproportionate influence over the decisions taken by the Fund. In this view, the Fund too often pursues policies that serve the interests of Wall Street and the US State Department rather than the world as a whole...[T]he IMF is too responsive to the agendas of national governments (the governments of its principal shareholders in particular)...The US government's prominence in international financial markets and large voting share in the Board enable it to exercise a disproportionate influence over decision-making in the Fund" (De Gregorio, Eichengreen, Ito and Wyplosz, 1999, pp.1-4).

These authors propose that the IMF be given independence, in the manner of an independent central bank, in order to insulate it against pressure from the United States and other large share-holders.

It is unquestionably true that the United States has an influence on global governance that is more than proportionate to its economic size, let alone to its population. Three of many instances where it is widely believed that the US Treasury wielded heavy influence in the IMF include: February 1995 when the US persuaded Managing Director Michel Camdessus to ram through emergency financial support for its neighbor, Mexico, despite opposition from some other major shareholders; December 1997 when a U.S. Assistant Secretary of the Treasury went to Seoul to tell the Korean government what would be the conditions of its IMF program; and several instances during the 1990s when the Fund was arm-twisted to make a lenient interpretation of Russian compliance with the terms of past programs, to prevent the world's number two nuclear power from going into default. This record has been accompanied by steady grumbling, and worse, on the part of other industrialized countries, especially in Europe, as well as developing countries.

If one wished to pass judgment on this state of affairs, much would depend on how well one thought the United States has used its power -- intelligently or incompetently, benevolently or selfishly. It is the view of the authors that the power was used well in the emerging market crises of the 1990s, when one considers the policy choices that had to be made, and avoids comparing the actual outcomes with unattainable alternatives. Consider the example of the policy toward Russia, much-maligned on account of corruption in that country and the ultimate failure of the IMF program in August 1998. There simply did not exist an option that read "first end corruption and establish rule of law; then support enlightened economic reform." The IMF has to work with the government in place, especially if it is democratically elected. It is not the United States alone, but everyone, that has a high stake in a stable and happy Russia. On the one hand, not to have supported Yeltsin when the best reformers in a century were in the government would have been to say that the West was never prepared to help Russia. This is true even knowing full-well Russia's corruption and other problems. On the other hand, to have continued supporting Yeltsin in August 1998 would have been reliably to throw good money after bad. This is true even knowing full-well that the alternative was 
default and devaluation. The combination of support when there was a chance that reform would work, and pulling the plug when the moral hazard had become severe, sent the right combination of signals. Either a policy of never helping or a policy of always helping would have sent much worse signals.

The considerable power of the US Treasury may not always be wielded as wisely as we feel that it was in the crises of 1995-2000. There are broader issues of international political economy at stake, however, that would be relevant even aside from the quality of personnel in any future US Administration.

The most important argument in favor of US role is the classic argument of international relations theory that the world needs a leader, to organize the delivery of "public goods" such as international monetary stability. In a world of many small or medium-sized powers, the free-rider problem would prevent effective collective action: it does not pay for any one country to organize or sustain multilateral cooperation. Charles Kindleberger has argued that Great Britain was the hegemon before World War I -- the guarantor of free trade, the gold standard, and the Pax Brittanica. In this view, the fundamental reason for the economic, political and military horrors of 1919-1944 was that Britain had lost the capacity to act as hegemon, and the United States had not yet gained the will to play the role. The fundamental reason for the relative harmony and prosperity of the post-war period is that the United States did play that role, in part through the IMF and other multilateral institutions, and has continued to do so in the management of recent crises in emerging markets.

While the U.S. has played a leadership role in international financial affairs and the management of recent crises, one should not overstate the hegemonic role of the U.S. The G-7 process, both at the level of Heads of State and Finance Ministers, works on a consensus basis. The U.S. may have provided leadership in crisis management, in proposals for the reform of the international financial architecture, for private sector involvement (PSI) in crisis resolution and in reform of international financial institutions (IFIs: IMF and Multilateral Development Banks - MDBs), but the process that has led to the implementation of these reforms has operated through a broader consensus. For example, on architecture reform, PSI and IFIs reform, initial U.S. and other countries proposals lead to an inter G-7 dialogue and eventually to a G-7 consensus on these policies and reforms. Next, other emerging market countries were involved in the process (in a number of fora: G22, G33, G20, FSF, et cetera) so as to reach a global consensus and decisions to approve the reforms within the IMF Executive Board, where all member countries are directly or indirectly represented.

A valid question is whether the United States is up to the role of global leadership. It showed that capacity after the end of World War II; but can it now, 50 years later? In one way, the United States is well-suited for hegemony: its domestic economic and political system sets a good example for the rest of the world, a model that is attractive and overall beneficial. In another way it is ill-suited to be global leader: many in the public, and especially in the Congress, have lost interest in the role. We consider this latter problem.

\section{II.B.1. Lack of domestic US support for internationalism}


Many Americans are now reluctant to pay the price for global leadership, even when the price is small. There is a lack of interest in internationalism. The US has won the Cold War, as well as the international economic competition, but may not be sufficiently interested in collecting its winnings to put down the small deposit required for the job of hegemon.

Examples come readily to mind. As recently as 30 years ago, it would have seemed a great "deal" for the US to be able to exercise influence in the IMF that is more than proportionate to the size of our quota; in 1998 Congress was very reluctant to approve the US share of the quota increases. 30 years ago the US criticized the Russians for neglecting to pay their UN dues; in the 1990s the US was the one chronically in arrears. Ever since 1974 the US Congress has given presidents authority to negotiate trade agreements on a fast-track basis, but Congress continued to deny this authority to President Clinton. The US seems unconcerned that it is almost completely isolated in its position in international negotiations over such issues as the landmines treaty, International Criminal Court, Kyoto Protocol, Comprehensive Test Ban Treaty, and the ABM treaty.

Ten years ago, much of this reluctance on the part of the American congress and public to play an active role in the world had already become evident. But in the 1980s the fear was that the US economy was in decline, particularly compared to Japan and other East Asian countries. It was said that the US could no longer afford the cost of leadership as it could have when it had the world's strongest economy. Even at that time, there were serious flaws in this argument. The decline in US economic performance was only relative to others, the natural result of gradual economic catch-up in GDP per capita on the part of many countries. If in the immediate postwar period the US could afford the vast sums involved in the Marshall Plan, it is hard to see why it could not afford to remain the leading aid-giver (for example) at a time when its income was considerably higher than in the 1950s.

But it is perhaps more surprising that the reluctance of the US Congress to exercise global leadership continued, even deepened, in the 1990s -- surprising because US economic performance has been so spectacular, whether measured by the length of the expansion (more than nine years, an all-time record), the average growth rate (4 percent in recent years), the swing from budget deficit to surplus (records in both cases), or the low rates of unemployment and inflation (to the levels of the 1950s).

The lack of domestic support for internationalism is a serious minus for US leadership. Poll results show a higher level of support among the general public than one might think. A poll by the Chicago Council on Foreign Relations found that $61 \%$ of the public (and $96 \%$ of leaders) support an active US role in world, and that $54 \%$ think globalization has been good for America. A poll by the Program on International Policy Attitudes found that 61 percent of Americans favored globalization, almost 80 percent of respondents supported more international cooperation, and a plurality even supported a stronger IMF. But evidently few people feel strongly about foreign affairs issues, except when they think their economic interests are specifically at stake or when they have relevant ethnic ties. The poll results do not translate into support in Congress.

An amateur political scientist can think of five interrelated reasons for a decline in political support for international initiatives: 
(1) The end of the cold war. When the US was in a global contest with the Soviet Union, many in Congress were willing to support initiatives that they were told would contribute. This ended with the breakup of the Soviet Union.

(2) Reversion to pre-1941 isolationism. During most of its history, the United States avoided "entangling alliances." It was a reluctant entrant into the two world wars. The period of strong support for international engagement was a deviation from normal, attributable to the experience of those wars, and to a conviction that the Europeans could evidently not be trusted to manage their own affairs.

(3) The passing of the WWII generation. By now, those who had the experience of living through and fighting the war have retired from the ranks of Senators and presidential candidates. Perhaps those who have taken their place have less appreciation for the longterm dangers of staying out of international affairs. One is tempted to make an analogy with stock market crashes, and with the theory that tolerance for risk in the stock market has been rising since the generation of investors who witnessed 1929 has passed from the scene.

(4) Lack of trust in elites. Until recently, most voters would accept the word of experts and leaders that fast-track negotiating authority or IDA replenishment were necessary, even if they did not understand them. In the wake of Vietnam, Watergate, and so on people no longer trust elites on any issue. Thus they are unwilling to take their word for it in the area of international finance.

(5) A general feeling that money is wasted by international bureaucracies. Polls show that voters think the United States spends far more on foreign aid than it actually does. Apparently they would be willing to allocate more than we currently do if they thought the money would be spent efficiently. ${ }^{35}$

\section{II.B.2. The US Congress}

The relevance of America's constitutional separation of powers is not a mere abstraction. The government has been substantively divided in most recent years. For example the Executive and Legislative branches have been in the hands of different parties since January 1995. In 1998, at the height of the emerging market crises, the Congress initiated proceedings to impeach the president.

Throughout the postwar period, the American Executive has generally been committed to international engagement. This was as true of President Clinton as his predecessors. In the economic sphere, the biggest international accomplishments in the first Clinton Administration were probably the passage of the WTO and NAFTA legislation, and the Mexican rescue program, and in the second Administration, the management of the East Asia crisis.

The Congress has been much less supportive. Congress showed its resistance to the Clinton Administration's activist approach to emerging market crises in a number of ways. Two of the most important were (1) its opposition to the use of government funds in the Mexican peso crisis, and (2) its initial opposition to an increase in resources for the International Monetary Fund in 1997-98.

\footnotetext{
${ }^{35}$ Most measures relevant for emerging market crises are not foreign aid. Even the quota contributions to the International Monetary are not budgetary costs but rather asset-exchanges.
} 
In January 1995, the first attempt by the Administration to put together a Mexican support package would have required Congressional approval. Notwithstanding that the Senate Majority leader and the Speaker of the House (the newly installed Newt Gingrich) agreed in a White House meeting to support the request, the rank and file in Congress rebelled. By the end of February, the Administration was forced to give up on Congress, and use the Treasury's Exchange Stabilization Fund instead. Use of the ESF is at the discretion of the Secretary of the Treasury. ${ }^{36}$ The Mexico policy worked well: financial confidence quickly stabilized, the Mexican economy (after an admittedly severe recession) recovered in the second year, and the US Treasury loan was repaid ahead of schedule, at a profitable interest rate. (We consider in the next Section below the argument that this policy, by posing a moral hazard of "bailout," sowed the seeds for the East Asia crisis three years later.) In any case, many in Congress showed anger that the Administration had gone ahead. The D'Amato Amendment retaliated by putting severe restrictions on the Treasury's use of the ESF.

When the Thai crisis broke in July 1997, the US was not one of the countries that contributed bilateral funds to the rescue package. In retrospect this was probably a mistake, in light of the ensuing contagion to much of the world. Certainly the Thais were offended that the United States did not contribute, whereas American funds were made available as part of the "second line of defense" in the Korean and Indonesian rescue packages a few months later. But a key difference was that the D'Amato amendment expired in between the dates of the Thai rescue and the subsequent crises, freeing up the ESF. Thus, if it was indeed a mistake for the US not to participate, at a time when the Thais were prepared to make needed policy reforms and the systemic crisis arguably might have been nipped in the bud, the mistake could be attributed to Congress.

Many in Congress continued their hostility to Administration efforts, whether out of genuine concerns along the lines of moral hazard, or with the motive of seizing an opportunity to make political hay. Congress refused to approve the Administration's request that the US contribute its $\$ 18$ billion share of an increase in IMF resources which was to consist of an increase in members' capital quotas and the establishment of the New Arrangements to Borrow. Sentiment in Congress did not begin to change until the Russian default in July 1998 ushered in Round II of the crisis. Many market observers were caught by surprise, having expected the G-7 and IMF to continue to bail Moscow out under the logic that it was "too important to fail."

For better or worse, some market observers concluded from the Russian default that the IMF might have run out of resources. (Others drew the lesson that unilateral sovereign defaults on bonds had suddenly become more respectable. The most important of the three possible lessons that could have been drawn, that the IMF and G-7 were after all serious about conditionality, was the slowest to win acceptance.) In any case, investors everywhere fled from risk and loaded up on liquidity. An unprecedented contagion spread to Brazil and throughout the Western Hemisphere. Sovereign spreads on emerging market debt rose to 15 percentage points above Treasuries in September. The excess demand for liquidity affected US financial markets, most notably in the form of the near-collapse of Long Term Capital Management. Spreads on corporate bonds rose. Newsmagazines put aside their New Economy or Overheating Economy cover stories, and instead began to ask if a global economic meltdown was imminent.

\footnotetext{
${ }^{36}$ Henning (1999).
} 
President Clinton's speech on the subject of the crisis in September 1998, before the Council on Foreign Relations in New York, implicitly responded to fears that he and other G-7 leaders had been too preoccupied with domestic matters to pay attention. He made evident that there was indeed "someone minding the store." 37 There, and at the IMF Annual Meetings the following month, the White House laid out a series of initiatives to address the current crisis and as well to reform the financial architecture so as to avoid future repeats. (The signal of a change in global monetary policy was discussed in the first section of the chapter.) The President also, for the first time, used the word "irresponsible," in describing Congressional foot-dragging on IMF funding. Some congressmen began to worry that if a global recession were really to take place, they would be blamed.

Finally in October Congress responded by passing the funding package for the IMF, opening the way for about $\$ 90$ billion of usable resources to be provided by all IMF members. The financial refueling of the IMF, in conjunction with the easing of monetary policy and various G-7 initiatives, probably contributed substantially to the subsequent weathering of the stresses on Brazil and the easing of the crisis worldwide.

There is one sense in which the low and variable level of congressional support for American international engagement generally, or for bailouts in particular, is useful. That is the doctrine of constructive ambiguity in bailout policy. ${ }^{38}$ Consider the analogy of the domestic lender of last resort. The Federal Reserve does not admit to having a policy that some banks are automatically "too big to fail." To reduce moral hazard, it seeks to maintain ambiguity as to whom it would bail out. In the case of the largest banks, this coyness is not credible. They are too important to the payments system and thus to the entire economy to be allowed to fail. This is a moral hazard problem with no good solution. At the international level, US claims that in the future it will not necessarily bail out troubled debtors are more credible. In the event of a repeat crisis, it may be that a future Executive will seek once again to put together a rescue package for suitably deserving and systemically important countries. ${ }^{39}$ But nobody can be confident that the Congress will go along. Thus the constructive ambiguity is credible.

\section{II.C. Moral Hazard and Private Sector Involvement (PSI) in Crisis Resolution $^{40}$}

The problem of moral hazard, and attempts to address it by involving private investors in any rescue package, are relevant to any attempt at crisis management.

\footnotetext{
${ }^{37}$ Waldman $(2000,230-236$.

${ }^{38}$ See the longer discussion of international lenders of last resort, in part VI.A of the paper.

${ }^{39}$ This is equally true whether the president is a Democrat or Republican. It is only after they leave office that policy-makers such as former Secretary of State George Schultz decide that the IMF should be abolished (Schultz, Simon, and Wriston, 1998). The first Reagan Administration made full use of the IMF and US funds, to bail out countries in Latin America and elsewhere that had more profligate fiscal and monetary policies, larger state sectors, and less liberalized economies, than the emerging market countries that the IMF rescued in 1995-98.

${ }^{40}$ See Roubini (2000) for a more detailed discussion of the bail-in, burden sharing and PSI debate and issues.
} 


\section{C. 1. Introduction}

The issue of the appropriate ways to involve the private sector in crisis resolution has been one of the most hotly debated and contested policy questions to emerge since the onset of currency and financial crises in the $1990 \mathrm{~s} .{ }^{41}$ It is one of the core issues in the current debate on the reform of the international financial architecture.

Even the definition of the problem is controversial. The issue under consideration has been defined by different authors as the "bail-in" issue (as opposed to "bail-out), the "burden sharing" issue, the "private sector involvement" question and, most recently, the "constructive engagement" of the private sector question. ${ }^{42}$ The definitional semantics are themselves loaded with the views of different actors (creditors, debtors and the official sector) of what such involvement should be. The issue of PSI remains highly contentious and complex.

In a sense, PSI is not new at all. The evolving strategy to deal with the international debt crisis of the 1980s already implied a significant, and somewhat coercive, involvement of the private sector in crisis resolution: sovereigns stopped payments on their syndicated loans to international banks, significant debt servicing difficulties emerged, bank loans were first rescheduled, then restructured and rolled over; new money was at times put on the table; and eventually debt reduction came via the Brady plan workouts. ${ }^{43}$

What was new in the 1990s was not PSI but the nature of the debt instruments, creditors, and debtors. As for instruments, bonded debt, short-term interbank loans, other structured debt securities and derivative instruments have increasingly supplanted syndicated medium-long term bank loans. As regards creditors, commercial banks have been increasingly supplanted by a whole host of other creditors such as small and large

\footnotetext{
${ }^{41}$ Recent official-sector views and policy on PSI can be found in Köhler (2000), Fischer (2000), Summers (2000), Geithner (2000), Group of Seven (1999, 2000) and IMF (1999). Private sector views include IIF (1999a, 1999b), Corrigan (2000), Bucheit (2000a), Cline (2000), Dallara (1999), Kahn (2000), Independent Task Force (2000) and Checki and Stern (2000). Some academic views include Roubini (2000), Eichengreen (1999b, 2000), Eichengreen and Ruhl (2000), Dooley (2000), Portes (2000), Friedman (2000), Haldane (1999), Kenen (2001) and Rogoff (2000).
}

${ }^{42}$ A first term used to discuss this issue was "bail-in" as a way to connote the need to avoid systematic "bail-outs" of private sector creditors during crises. This term was deemed a bit too coercive by some who preferred instead the term "burden sharing". But even the latter phrase was contested as suggesting equity considerations rather than the need to fill a financing gap; the term also had coercive connotations that appear at odds with the goal of constructively involving the private sector in crisis prevention and resolution. Thus, the increasing use by the official sector of the term "private sector involvement in crisis resolution" (often referred to as PSI policy) with the adjective "appropriate" often added in front of PSI to stress the view that such involvement should be as voluntary, constructive and cooperative as possible. Most recently, the new IMF Managing Director Köhler (as well as Stanley Fischer) have suggested a new phrase, "constructive engagement," that emphasizes the need for voluntary and market based solutions, as opposed to forced or coercive approaches, to private sector involvement. Unfortunately this series of increasingly less explicit terms has made it harder and harder for the non-specialist to know what is meant.

${ }^{43}$ A detailed discussion of PSI in the 1980s, from payment suspensions on syndicated loans in the early 1980s to the implementation of the Brady plan in the late1980s and 1990s is beyond the scope of this paper. Cline (1995) presents a comprehensive discussion of this issue. 
bondholders, investment banks, hedge funds and real money investors (such as mutual funds and pension funds). Among debtors, while sovereigns are still important, private sector debtors in emerging markets (such as financial institutions and corporations) are increasing their share of cross border borrowing.

While in the 1980s the challenge was to restructure and reschedule the loans of a limited set of commercial banks, the challenge in the 1990s became one of rescheduling and restructuring bonded instruments (as well as cross border short term interbank loans). Bond rescheduling was not an issue in the former period as bonded debt was mostly "de minimis" compared to bank loans. Initial attempts by the public sector to include bonded debt into PSI were received with skepticism by the private sector as well as the debtors. It was argued that, while in the 1980s, it was relatively easy to convince a small set of homogenous creditors subject to regulation and pliant to forbearance commercial banks - to reschedule a set of homogenous instruments (syndicated bank loans), it would have been impossible to restructure instruments such as bonds that did not have collective action clauses, that were very different and heterogeneous in their legal and economic features (Eurobonds, Brady bonds and other bonded securities) and were held by thousands of creditors who were marking to market, not heavily regulated, and neither willing to engage nor expert in bonded debt instrument restructuring. The collective action problem of coordinating the actions of such a disparate and large group of creditors without creditor committees, majority and sharing clauses was deemed to make it all but impossible to restructure bonds. Also, it was argued that the short-term nature of the interbank loans would make them hard to restructure: creditors would stop rolling them over and would close their positions before the debtors could even start thinking about a possible partially-involuntary rollover. The reality of PSI in the 1990s turned out to be quite different from these pessimistic assessments.

For one thing, the collective action problems were also quite serious in the 1980s: there were hundreds of commercial banks with different exposures and interests; the freerider or holdout problem was as serious then as now; and the debt instruments were quite heterogeneous, as hundreds of very different syndicated loans had to be repackaged and restructured. ${ }^{44}$ Moreover, as the recent restructuring of the bonded debt of Pakistan, Ukraine, Russia, and Ecuador, suggest, bonded debt restructuring is feasible even in the absence of ex-ante collective action clauses (CACs). Also, with the emergence of shortterm interbank loans in the $1990 \mathrm{~s}$, in part a reaction to the bail-in of longer term bank loans in the 1980s, a bail-in of such instruments became necessary to prevent liquidity driven runs. In different ways and with different degrees of coercion or voluntarism, the restructuring or monitored rollover of cross border interbank loans in Korea, Brazil, Russia, Indonesia and Turkey became part of the PSI policy of the 1990s.

Even the rationales for PSI have been contested and hotly debated. The official G7 doctrine on PSI stresses the following rationales. First, a current account or a capital account- based crisis creates an external financing gap. Even after the debtor makes domestic adjustments to policy and reduces domestic absorption as part of its policy

\footnotetext{
${ }^{44}$ Collective action problems were partly solved by having creditor committees where some financial institutions took a leadership role and prodded creditors to play ball with carrots and stick. The term "Rhodes Rolodex" has been used to characterize the central role played by Citicorp's Bill Rhodes in providing such coordinating and leadership role. Interestingly, he played a similar role in some of the 1990s restructuring episodes, namely in the case of Korea.
} 
adjustment process, a financing gap may remain because the amount of capital outflows and debt that has to be serviced is in excess of the foreign reserve resources of the country available for external debt service. Second, involvement of official creditors may contribute to filling this external financing gap but cannot fill it altogether. Even very generous Paris Club restructurings of official bilateral debt and normal access by multilateral creditors to financial support from the IMF, the World Bank and other Multilateral Development Banks may still leave a financing gap. In other words, official money, unless it is exceptionally large (a hotly contested issue) cannot in most cases fill in the debtor's entire financing gap. Third, exceptional financing is not only infeasible given political, financial and other constraints to large scale official support, but also undesirable, apart from a few special cases. It is undesirable because expectations of official sector bailout of creditors would lead to severe moral hazard distortions of crossborder borrowing and lending. ${ }^{45}$ Thus, financing gaps, the limited availability of official money and moral hazard considerations are seen as the basis of the need for "appropriate" PSI in crisis resolution. ${ }^{46}$

\footnotetext{
${ }^{45}$ Throughout this section we use the term "bailout" interchangeably with "large official support". But the term bailout has specific positive and normative connotations. When large scale official finance is provided to a debtor country, this is not technically a bailout if the funds are eventually repaid to the IMF and official creditors. Indeed, in the recent episodes of large scale support (Mexico, Korea, Thailand, Indonesia, Brazil . Russia) IMF loans have been repaid or have been serviced according to the terms of the lending. Still, some argue that these official loans have some subsidy component but this alleged subsidization is far from a "bailout". One could argue that this official lending is a bailout in that it bails out international creditors of the sovereign or its private firms (banks and corporates). But even in this case the term "bailout" may be inappropriate: as long as the debtors (sovereign or private firms such as banks) are solvent, the creditors would be eventually repaid in full and the IMF support only changes the timing of their receipts.

Preventing the pospoment of debt payment servicing that would have occurred if official funds were not available is of value to international creditors (as effective restructuring/rollover/restretching of payments may have a net present value cost to them) but it is not, again, a full bailout. In cases in which the debtor is not solvent and a debt write-down would occur in the absence of official support, policies of PSI may effectively bail-in creditors and provide burden sharing. While the term "bailout" may thus be imprecise, in the following we will use the term in the loose form that has been used in the debate on bailouts versus bailins.

Note also the degree of coercion in PSI will vary a lot depending on the specific case studies. At one extreme are cases of "soft" PSI where international investors "commit" to maintain exposure (as international banks in the cases of Brazil and Turkey) or when debt restructuring occurs on voluntary and market terms (mega-swap in Argentina in 2001). More coercive forms of PSI are the case of Korea where international banks agreed to turn short term lines to Korean banks into medium term government guaranteed claims under the effective threat of a Korean default on such claims. Similarly, the restructuring of the sovereign bonded debt of Ukraine and Pakistan, while it did not imply a reduction in the principal value of the claims, it occurred at below market interest rates and thus implied some NPV reduction. At the other extreme are cases where the country has effectively defaulted - by suspending payments - on its domestic and/or foreign liabilities and the bonded debt restructuring implies a reduction in the principal value of the claims (Russia, Ecuador).

${ }^{46}$ Other goals of PSI have been mentioned from time to time. For example, the "unfairness" of bailing out private investors and having the official creditor sector fill in the full financing gap is behind the references to "burden sharing". But fairness and burden sharing can also be seen as motivated by the lack of enough official money ("there is not gonna be enough money to fill in all gaps") and the moral hazard distortions of large scale bailouts ("creditors and debtors would be reckless if they knew that the official sector stands ready to bail them out systematically").
} 
The basic logic behind the official approach to PSI was thus the need to finance external gaps, the limited availability of official money and the need to avoid moral hazard distortions. Thus, the initial private sector rejection of PSI in the financial community looks perplexing. But indeed, while the logic of PSI may have been quite uncontroversial, and even the private sector has reluctantly come to accept it, the application of PSI to specific cases, has remained complex and controversial. This section of the paper will thus make a broad assessment of the logic of PSI, the evolution of the official doctrine, its application to specific cases, and a wide range of open and controversial issues. ${ }^{47}$

First, note the type of creditors, debtors and instruments involved in crisis management and resolution and the degree of coerciveness of PSI has been very different in different crises in the 1990s (Mexico, Thailand, Korea, Indonesia, Malaysia, Russia, Brazil, Ecuador, Ukraine, Pakistan, Argentina, Turkey). At one extreme, there is the case of the 1994-95 Mexican crisis where there was no meaningful PSI of foreign investors as the amount of official resources provided by the IMF and the U.S. to Mexico was sufficient to allow all the foreign holders of short-term government debt (tesobonos) who were unwilling to rollover their instruments to exit from Mexico at maturity and with no losses. Very soft forms of PSI were implemented in the Brazilian case where, in addition to a large package of official support, private cross-border interbank lines were first monitored (starting in the fall of 1998) and next, international creditors committed to maintain interbank exposure to February 1999 levels. A similar but even softer form of PSI was implemented in Turkey where the December 2000 IMF package was accompanied by a soft monitoring of cross-border interbank lines and a generic commitment by international investors to maintain such lines. In the case of Argentina there was no meaningful PSI of foreign investors in the IMF package of December 2000 as the amounts of official support committed to the country were sufficient for the government to avoid, if necessary, borrowing new funds from international capital markets for most of 2001. However, there was some soft form of involvement of the domestic private sector as domestically based banks and pension funds committed in principle to purchase in 2001 determined amounts of government debt.

More coercive forms of PSI were implemented in Korea, Thailand and Indonesia. In Korea, in December 1997, foreign bank creditors of Korean banks were trying to repatriate most of the short term cross border interbank lines amounting to about $\$ 20$ billion. But, faced with the risk of an imminent suspension of payments given that Korea

\footnotetext{
${ }^{47}$ The discussion will concentrate on the role of PSI in crisis resolution while touching only marginal on the use of PSI for crisis prevention (which will be discussed in Part IV). For one thing, appropriate PSI for crisis prevention partly overlaps with crisis resolution. If a rollover of interbank loans is arranged - maybe through ex-ante coordination mechanisms such as creditors committees - before asset prices such as exchange rates, stock price and sovereign debt prices have collapsed, one can think of this as crisispreventing PSI. After the crisis is triggered, it becomes crisis-resolving PSI but the substance of the problem is quite similar. Many proposals for crisis prevention could be discussed: capital controls, standstills, creditor committees, voluntary rollovers, private contingent credit lines. We will touch on these as part of our discussion of crisis resolution rather than crisis prevention but a serious, difficult issue remains open. Ideally, one would want to involve constructively the private sector before, rather than after, the free fall of currency and other asset prices have caused recession, significant financial distress and bankruptcy of sovereigns, corporations and financial institutions. Thus, PSI for crisis prevention is preferable to that for crisis resolution. But how to avoid the crisis in the first place remains difficult.
} 
and its banks did not have enough foreign reserves to finance such a roll-off, international banks first agreed to rollover such lines and then, in March 1998, to turn them into medium term claims. This was a semi-coercive form of PSI, formally a form of concerted rollover facilitated by the actions of the U.S. Treasury and the New York Fed who helped to coordinate the collective action problem faced by the international creditors: international banks were effectively "forced" to accept the rollover and maturity transformation of their claims given the country's lack of reserves to finance a roll-off of such lines. Restructuring of short term international bank claims against the sovereign were implemented in Thailand and Indonesia even if the amounts at stake were much smaller than in Korea. However, in Indonesia the severe financial distress of corporates and banks also led to an effective standstill of private sector liabilities to foreign investors (mostly corporate debtors given the larger exposure of the corporate sector to international banks).

In Asia, sovereign bonded debt issued internationally was minimal; thus, the PSI in these countries did not involve bonded debt. Sovereign bonded debt restructurings, instead, were part of the PSI policy in Pakistan, Ukraine, Russia and Ecuador. While the restructuring of these claims was, at the end, voluntary in the sense that unilateral exchange offers were made by the sovereign and accepted by a large fraction on bond creditors, there was a significant amount of coerciveness as these restructurings were preceded by effective default (non-payment on the old instruments) as in Ecuador and Russia or threat of default (as in Pakistan and Ukraine). Also, while Mexico, Korea, Indonesia, Thailand, Brazil, Argentina and Turkey involved large official support packages together with policy adjustment and different degrees of PSI, the four bonded debt restructuring occurred in the context of smaller official support in the presence of large financing gaps. In Russia, the initially committed IMF package was large but, given the country's inability to implement conditionality requirements, actually disbursed amounts were smaller and the country decided to default on a broad range of its claims against foreign investors. The case of Malaysia was the only one not involving official creditors support, as the country did not request an IMF package. Thus, the country's own decision to impose capital controls in September 1998 was not formally an application by the IMF and G-7 of the official PSI doctrine. ${ }^{48}$ Such controls were, however, a form of standstills on some payments to foreign investors, and will be discussed below in the section on standstills.

The official PSI doctrine has also evolved over time. As discussed above, PSI was part and parcel of the official strategy to deal with the 1980s debt crisis including the Baker Plan of 1985 and culminating in the Brady plan and its implementation in the early 1990s. The Mexican peso crisis of 1994-95, the first major capital-account based crisis of the 1990s, brought back the issue of whether and how appropriately to involve the private sector in crisis resolution. The effective bailout of private investors was ex-post successful given that Mexico was close to a liquidity run and that its economy rapidly and successfully recovered after official support. But it led to the now familiar concerns about moral hazard, political limits to the size of official support packages and the need for private sector involvement. The G-10 Rey Report came out in 1996 with recommendations about the need for collective action clauses (CACs), IMF lending into

\footnotetext{
${ }^{48}$ Formally, even the Russian case was not part of the official PSI policy as involving the private sector was not a requirement of the IMF program; the country decided on its own to default on some of claims.
} 
arrears and appropriate PSI. These recommendations were not implemented at that time but this debate resurged in the aftermath of the Asian crisis. The crisis brought back the question of PSI, both in practice and as a doctrine. Before official doctrine was formally fleshed out, dealing with the crisis cases led to effective private sector burden sharing in Korea, Indonesia and Thailand. These cases were limited to cross border bank loans (to financial institutions and corporates) and did not address the issue of restructuring bonds that were "de minimis" in these episodes. The official PSI doctrine was next developed as part of the attempt to reform the international financial architecture. The October 1998 reports of the G22 Group included one on private sector involvement in crisis prevention and resolution. The formal G7 doctrine was fleshed out in early 1999 in preparation for the July 1999 Koln G7 summit where PSI was addressed as one of the building blocks of the new international financial architecture. The Koln document on architecture reform included a large section on the new G7 PSI framework and doctrine.

This official doctrine can be characterized as a "case-by-case approach with principles and tools." While the approach was a case-by-case one, a series of clear principles and tools were provide to clarify the process to be used in implementing PSI. While some suggested the need for more precise rules to guide PSI, rigid rules were in the end deemed by the G7 as unrealistic. In this view, the complexity and novelty of the issues to be addressed did not allow a rigid set of rules. For example, under what circumstances would PSI be implemented? What kind of PSI would be appropriate in different cases: soft, semi-coercive, concerted, coercive? What claims are to be included in PSI: bonded debt, short-term interbank flows, other short-term credits, Eurobonds, Brady bonds, domestic debt (local and foreign currency denominated)? What class of creditors is to be included: foreign, domestic, bondholder, bank creditors? How much adjustment and how much filling of external gaps are required? And how would the financing gap be filled between multilateral creditors (IFIs), bilateral official creditors (Paris Club (PC) creditors) and the private sector? How is PC comparability to be defined? How is the financing pie to be divided among different creditors? Is PSI to come before or after a PC rescheduling? What about reverse comparability? How to restructure sovereign bonds: via a market soundings process followed by unilateral debt exchange offers, or by relying on committees and formal negotiations between debtors and creditors? Use collective action clauses or not? How much to micro-manage the restructuring process? What to do in liquidity cases? How to distinguish insolvency from illiquidity? ${ }^{49}$ This is only a partial list of the very difficult questions that the official sector had to address in designing its PSI policy. Since many of these questions did not have a simple answer, in the view of the G7 the case-by-case approach cum principles and tools for PSI provided the correct balance between the need to provide clear guidelines to market participants and the need to maintain the flexibility of the policy to address specific cases.

The official doctrine has also stressed two other points that are of paramount importance. First, PSI should be "as appropriate." This bland word is intended to signify that, in the G7 view, whether and what type of PSI was needed would have to be considered by case-by-case study. Blanket rules suggesting PSI for all countries in crisis and/or for all countries that may have an IMF program would be avoided. In each case, the merit of appropriate PSI would have to be carefully assessed. Second, strong

\footnotetext{
${ }^{49}$ Many of these questions are discussed in more detail in Roubini (2000).
} 
preference should be given to cooperative and voluntary solutions relative to more coercive solutions. Given the importance of enforcing international debt contracts and ensuring a steady flow of capital to emerging markets, semi-coercive or coercive solutions would be considered only in extreme situations and strong preference would be given to crisis resolution processes that are as non-coercive and as cooperative as possible. In the G7 view, the aim of PSI is not to "punish" or inflict losses on private sector investors. It is rather to resolve, ensuring appropriate financing of external financing gaps and creating conditions that facilitate stable flows of capital to emerging markets and support long run economic growth. At times, the private sector has perceived actions of the official sector as unfair, punitive and unpredictable but the G7 have argued that the whole PSI policy has been guided by an awareness of the importance of maintaining sound international capital markets and avoiding actions and policies that may disrupt flows of capital in undesirable ways.

The difficult tradeoff in official PSI policy was between the official desire to limit large money packages, while maintaining the option of having them when appropriate, and the desire to implement PSI policies that are as voluntary and cooperative as possible. This difficult tradeoff is, for example, apparent from the first remarks of the new IMF Managing Director on the issue of PSI (Köhler, 2000). On one side, he suggested a preference for limiting large official packages; on the other hand he strongly supported "constructive engagement" with the private sector which implies, among other things, a preference for cooperative and voluntary, as opposed to semi-coercive, solutions to crises. The two goals, while each separately valid, are at times in dialectic tension with each other. Less official money might mean more PSI (and at times more coercive forms of PSI when voluntary ones are not feasible), while more voluntary forms of PSI or of constructive engagement might require more, rather than less, official money. This basic tension between the desire to limit official finance and the goal of having constructive and voluntary forms of PSI has not been fully resolved in official doctrine and practice.

During the same period that the official PSI policy was being fleshed out, developments in the policy arena led to the first cases of bonded debt restructuring.

First, the Paris Club extended the comparability principle to bonded debt for the case of Pakistan in January of 1999; while the principle was not new, it had not been applied before to bonds as they were de minimis in most cases. The restructuring of Pakistan's Eurobonds and other bonded claims was then successfully performed in the fall of 1999.

Second, the pressures on the Brazilian currency in the fall of 1998 that eventually led to the devaluation and float of this currency in January 1999 posed again the issue of whether and how to appropriately involve the private sector in crisis resolution. Crossborder short-term bank lines were, again as in Korea, at stake and in risk of no rollover; moreover, a large stock of very short term domestic debt was also subject to roll over risk. Eventually, the form of PSI in Brazil turned out to be very mild with a system of monitoring of bank lines followed by a mild commitment in March 1999 to maintain exposures to February levels. Such mild PSI worked as the catalytic role of the official package and the adjustment efforts of the country prevented a destabilizing loss of confidence and eventually restored economic growth without the need to resort to coercive outcomes. 
Third, large external financing gaps debt servicing difficulties in 1999 by Romania and Ukraine led to attempts to restructures their bonded liabilities ${ }^{50}$. Such attempts were ad-hoc and only partially successful: PSI in Romania was attempted (the official policy was to consider bond restructuring but then to back down and let Romania pay its maturing instruments in return for promise to raise new money) but eventually abandoned. The debt and bond restructurings in Ukraine (the structured note in 1998, the ING structured note in the summer of 1999 and an ECU-based claim in the fall of 1999) were first partial, ad-hoc and unsustainable over the medium term as the strict market approach led to restructurings that were of very short maturity and at interest rates that were unsustainable in the medium term. Only later in 2000, Ukraine took a comprehensive approach to its bonded debt restructuring (restructuring of "Eurobonds" and an assortment of Eurobond-like instruments created in earlier restructurings).

Fourth, the effective default of Russian debt following the August 1998 crisis led to a process that would eventually lead to the restructuring in 2000 of its bank and bonded liabilities. 51

Fifth, the effective decision by Ecuador to stop payments on its external debt in August 1999 represented the first episode where the previously restructured Brady bonds were effectively defaulted upon leading to the need to restructure them (as eventually was successfully implemented in July-August 2000).

Sixth, the drive to restructure bonds via market based debt exchanges was successfully implemented in 1999 and 2000 in Russia and Ukraine (a comprehensive deal for Ukraine in 2000 rather than the ad-hoc deals in 1998-99) after the successful Pakistani episode. And Ecuador's bonded debt exchange was successfully launched and completed in July-August 2000.

As these test cases played themselves out, the official doctrine evolved as well. While the case-by-case approach was maintained and deemed appropriate given the complexity and differences of cases, the G7 agreed in April 2000 on a set of "operational guidelines" for PSI, in part as a response to private sector requests for greater clarity. These guidelines were reaffirmed as part of the Finance Ministers Communiqué prepared for the July 2000 G-7 summit in Fukuoka, Japan and approved at the IMF September 2000 annual meetings in Prague.

One other general point is worth discussing at this stage. The form of PSI will depend on where a debtor country stands in the broad spectrum that goes from pure "liquidity" cases to pure "insolvency" cases. This is a most complex issue. First, deciding whether a country is insolvent or not is very hard given that debt servicing depends both on "ability to pay" and "willingness to pay." Second, the spectrum of cases is not limited to corners of pure illiquidity and pure insolvency cases but is more gray and continuous. Often, countries that are mostly illiquid have significant policy problems

50 Strictly speaking, the first restructuring case was Ukraine in 1998; in that case, the instrument was not a classic bond but a structured financing (local currency claim packaged with guaranteed access to foreign exchange from the central bank). This was not strictly a bond restructuring but certainly a restructuring of something that was not a bank line.

${ }^{51}$ First, there was the default on GKO and non-deliverable forwards (NDF) in August 1998; then, cascading defaults on Min Fins, Prins, Ians and other Soviet era debt eventually lead to a restructuring of a broad range of external and domestic London Club and bonded obligations. 
(such as Mexico in 1994 and Korea in 1997), so that a simple solution such as full unconditional large official support without any PSI may not be feasible. At the other end, countries that look insolvent (for example Ecuador) may eventually be able to service their restructured - rather than reduced - debt if they implement enough policy adjustment. In between the cases of liquidity (with or without policy problems) and the pure cases of insolvency, there are many cases of countries with significant macro and structural adjustment problems whose debt burden may not be unsustainable in the long run but who do face significant payment humps in the short run (Pakistan, Ukraine, Romania). In these cases some form of PSI short of outright debt reduction may be adequate to solve the payment problems of these countries.

One could argue that the severity of the PSI policy will depend on where a country stands along this spectrum. Debt reduction is inevitable for clear cases of insolvency subject to a country effort to adjust its underlying problems. Debt restructuring, rescheduling and rollovers that do not formally touch the face value of principal payments may be warranted in cases where severe policy problem exist, the debt burden is not unsustainable but payment humps and lack of market access do not allow the country to service its debt in full and on time in the short run. ${ }^{52}$ A solution closer to large official support packages (full bailout) may be warranted because of favorable externalities in cases of pure illiquidity, especially if the country is large and of systemic importance. But, as we will discuss in detail below in Section VI, the role PSI in such liquidity cases is a more complex issue than this simple logic suggests.

\section{C. 2. Moral Hazard}

The issue of moral hazard in international capital flows has been hotly debated. Moral hazard in this context has to do with the potential distortions deriving from implicit and/or explicit official guarantees of debts and the potential effects of official creditors' support packages. Since one of the fundamental rationales for PSI is the idea that excessive official support may lead to moral hazard it is important to assess the importance of this distortion in international capital markets.

Some definitional distinctions are important. One can be concerned about debtor's moral hazard or creditor's moral hazard. The debtor's moral hazard arises if official money (in the form of multilateral and bilateral lending and support) reduces the incentive of a debtor to follow sound policies in the first place and affects its incentives regarding payments on its external liabilities to foreign private investors. Even within the class of debtor moral hazard, one may want to distinguish between the moral hazard of the sovereign and the moral hazard of domestic private agents. The latter refers to the case where implicit or explicit government guarantees lead domestic agents in emerging markets (financial institutions, corporations and households) to borrow excessively (directly and/or indirectly from foreign creditors) relative to what would be optimal, and to make distorted investment decisions. Debtor government's moral hazard derives

\footnotetext{
52 Even in such cases, the restructuring will imply some NPV reduction of the debt as interest rate and principal payments will be rescheduled at rates that are below current market rates. Thus, some real debt reduction will occur and does occur even in cases in which face value reduction is not formally performed. As official bilateral claims are also rescheduled at rates that do not truly reflect repayment risk, PC debt is also subject to effective NPV reduction even if it is formally not written down. This was discussed in more detail in section II.A.
} 
instead from expectations that some external official agent (multilateral or bilateral official creditors) will provide bailout support to a country, thus leading ex-ante the sovereign to follow loose economic policies that may eventually cause economic and financial problems. Creditor's moral hazard refers to the distortions in the lending decisions of international creditors that derive either from expectations that the official creditor sector will bail-out a sovereign or from expectations that a sovereign will ex-post guarantee liabilities of its private sector that have been incurred with private international creditors. ${ }^{53}$

There is a broad range of views on the analytical and practical importance of moral hazard distortions in international capital flows. Some, such as Calomiris (1998a), Schwartz (1998), Dooley (1999), Chinn, Dooley and Shrestha (1999) and Corsetti, Pesenti and Roubini (1999a, 1999b) believe that such distortions are critical, while others such as Summers (2000) and the IIF (1999) think that such distortions are less important than others have made out. The issue is obviously one of quantitative degree rather than absolutes. Official policy has always the potential to lead to moral hazard; the issue is how important the distortion is.

The different views on moral hazard and the determinants of the flows to emerging markets in the 1990 s are hard to test. ${ }^{54}$ Formal and systematic evidence on these issues is scarce. There is, however, some recent econometric evidence. A paper from the Institute of International Finance (1999c) attempts to test formally for moral hazard, by trying to assess whether the significant reduction in sovereign spreads in the period before the Asian crisis can be explained by fundamentals or could be related to bailout expectations following the Mexican rescue. This study does not find evidence of moral hazard. Lane and Phillips (2000) consider whether IMF programs are a source of moral hazard. They find that this type of moral hazard is difficult to detect in market reactions to various IMF policy announcements and there is no evidence that such moral hazard has recently been on the rise. Dell'Ariccia, Goedde and Zettelmeyer (2000) have also tested for moral hazard by considering sovereign spreads and their variance before and after the Russian crisis; they find partial, and mixed, evidence of moral hazard in this episode. More circumstantial evidence suggests that investors may have expected large official support packages for systemically important countries in recent episodes of financial turmoil such as Russia in 1998, Brazil in 1998-1999, Argentina and Turkey in 2000.

Both debtor moral hazard and creditor's moral hazard deriving from expectations of bailout via official support are important enough to be a concern for the design of an efficient international financial system. Moral hazard affects issues such as the desirability of an international lender of last resort, the optimality of official support packages and the issue of whether and what form of PSI is appropriate. The overall analytical and empirical evidence suggests that the moral hazard rationale for PSI is a valid argument for appropriate forms of private sector involvement in crisis resolution.

\footnotetext{
${ }^{53}$ Even when governments have declared ex ante that they will not guarantee private claims, they are often nonetheless forced to take responsibility when the time comes. Chile in the early 1980 s was a case in point. Korea's guarantee of cross border banks liabilities in late 1997 is another example from the recent Asian crisis. Turkey is a more recent case during the November-December 2000 turmoil in its markets when it decided to guarantee all bank liabilities, including the cross border ones.

${ }^{54}$ See Roubini (2000) for a more detail discussion of these arguments.
} 


\section{II.C. 3. Issues with standstills}

Several authors have suggested that some broad debt standstills (suspension of debt payments) may at times be necessary, either to prevent a period of turmoil from turning into a full blown crisis or to prevent further overshooting of asset prices and the risk of an outright default once a crisis has occurred. This is certainly a most controversial issue. Support for the idea of standstills comes not only from academic economists but also, cautiously, from some official sector representatives within the G-7 group (see King (1999) for example). ${ }^{55}$

A standstill, if temporary, can be seen as a radical form of "bailing-in" the private sector and, according to some, it is a better and more orderly way to gain time and restore confidence than a disorderly rush to the exits. A standstill could be the right policy response both in liquidity cases when there is an "irrational" rush to the exits and in other crisis situations, where serious policy problems are afflicting the debtor country, but the rush to the exits of creditors is disorderly and threatening to create a worse outcome.

Standstills pose a lot of complex questions. What are the risks and benefits of standstills? Would they include only sovereign payments or payments on all debtor country's claims, including by the private sector? Do standstills require systematic capital and exchange controls? Would they be sanctioned by the IMF or the official sector? Could they be associated with a stay of litigation?

Consider the potential benefits of standstills. In pure liquidity cases where there is uncertainty and no risk aversion, the threat of a standstill is enough to support the good equilibrium, i.e. ex-post there is no need to implement the threat and agents will avoid rushing to the exits if they know that everyone would be locked in. ${ }^{56}$ In reality, uncertainty, risk aversion and policy problems make this first best equilibrium unlikely and standstills would have to be introduced (rather than just threatened) to prevent investors from rushing to the doors.

If standstills have to be imposed, what are their benefits? The main benefit may be to prevent a disorderly "rush to the exits" when, even allowing that the country may have serious policy problems, investors panic and overreact to the negative developments. Such a disorderly rush is inefficient for two reasons: first, it may force the debtor into effective default (inability to make debt payments) when, even if solvency is not at stake, the stock of foreign reserves is below the short-term claims that are coming to maturity and are not being rolled over. Second, when the exchange rate is allowed to float rather than being fixed, the rush to the exits may lead to severe overshooting of the exchange rate. That, in turn, may be extremely costly if it leads to financial distress and bankruptcy of a large set of debtors, sovereign and private.

Take for example the cases of Korea and Indonesia. If the concerted rollover of cross-border interbank loans in Korea had occurred by Thanksgiving 1997 rather than a month later at Christmas, widespread financial distress would have been limited. The difference between the two dates is that, at the former, the won/ US \$ exchange rate had fallen from 900 to 1,100 (beneficial in terms of competitiveness) while by Christmas it

\footnotetext{
55 See IMF (2000a, 2000b) for a discussion of standstills and the debate on them at a recent IMF Board meeting.

${ }^{56}$ See section VI.A below for a broader discussion of standstill and other issues in liquidity cases.
} 
had fallen to over 1,800 (causing widespread financial distress). Although many chaebols were already distressed earlier in 1997 before the fall of the won, 1,800 was a rate at which many more foreign currency debtors, financial firms and corporates, were effectively distressed if not bankrupt. Thus, the implication of the delay in the concerted rollover was a significant worsening of the financial conditions of Korea and a worsening of the real output effects of the exchange rate shock.

In the case of Indonesia, some have argued that the lack of an early standstill on payments by the local corporates to their international creditors contributed to the free fall of the currency. The collapse in the value of the currency, particularly the move of the rupiah / US \$ exchange rate from 4,000 to 8,000 and then 12,000 (and above) led to the widespread effective bankruptcy of most financial institutions and firms in the country. At the end, the burden of foreign debt was so high, given the fall in the value of the currency, that these corporates effectively stopped payments. An informal standstill of corporate liabilities occurred by default in a situation of complete financial distress of these firms.

The above arguments suggest that an early standstill might have helped to minimize the costs of further turmoil that derived from a lack of orderly workouts. But the reality is more complex. In the case of Indonesia one could argue that the depreciation of the rupiah had less to do with the attempt of corporates to hedge their foreign currency positions and more with government failures that shook confidence in the country. The lack of commitment to structural reform, political uncertainty, the health of Suharto and his crumbling power regime, the monetization policy of Bank of Indonesia, the capital flight of the ethnic Chinese exposed to violent attacks were all more important than hedging demand in driving the rupiah into free fall. In the absence of a more serious and credible adjustment program, it is likely that a standstill would not have worked out and would have failed to stem the fall of the rupiah and the generalized panic that enveloped domestic and foreign investors. Flight and asset stripping might have continued even under strict capital and exchange controls, given the many sources of leakage in capital flows. So, it is not obvious that a standstill on private payments would have worked. Also, standstills on payments by private firms are harder to arrange than on sovereign payments. The difficult issues include who will declare one and how to enforce it.

Again, in the case of Korea, it is not clear that a standstill would have worked. The won started to fall precipitously in early December when, in spite of an IMF program, a series of bad news hit markets: the low level of reserves was revealed, the extra offshore liabilities of Korean financial institutions and chaebols emerged, the upcoming election and the policy uncertainty around it became important sources of uncertainty and of concern about the willingness of the government to implement reforms credibly. Also, all the players in the game -- international creditors, the Korean government and official creditors -- were not ready early on to go for a concerted rollover. It was only when - at the end of December - it became clear that Korean banks were on the verge of defaulting on their liabilities that a concerted rollover became feasible and acceptable to creditors.

The case of the Malaysian capital controls in September 1999 was not formally a case of implementation of PSI as part of a package of official support as the country did not request an IMF package and did not rely on official creditor financial support. Instead, the country decided to impose capital controls as a way to regain monetary 
autonomy in the presence of large pressures on its currency. Some of the capital control measures (such as closing down the offshore ringitt market) did not formally represent PSI; others, such as the temporary restrictions to foreign investors' ability to repatriate portfolio investments in Malaysia were a clear form of coercive bailing-in of foreign investors. Note that Malaysia did not impose a standstill on sovereign liabilities payments but these liabilities were negligible to begin with.

Standstills have a number of other potential drawbacks that need to be considered.

First, standstills may reduce in the medium-long run the amount of capital flowing to emerging markets if they are perceived to be a tool used by debtors to opportunistically default on their debt obligations.

Second, as in the case of anticipated capital controls, anticipations of a standstill may lead to an earlier crisis (as all investors rush to the doors in expectation that the doors will be shut) or, worse, can even trigger a crisis that would have not otherwise occurred. This is the main drawback, one that cannot be avoided if there are clear rules that imply some automatic standstills in some circumstances. Constructive ambiguity, in place of rules, may help but if investors fear that standstills will be imposed with some probability (even without mechanical rules) the rush to the exits may occur anyway. Proponents of standstills have not seriously addressed this main shortcoming of the tool. For example, it is clear that the Korean concerted rollover in December 1997 led investors to believe that such semi-coercive policy might be imposed on Brazil as well. The sharp reduction in interbank exposures to Brazil in the summer and fall of 1998 was clearly affected by the experience of Korea - and that of Malaysia in September 1998 and expectations that similar coercive solutions might be imposed in Brazil. In the case of Malaysia, capital controls of the type that were eventually imposed in September 1998, were widely predicted throughout 1998 as being likely to be implemented. Thus, some of the capital flight and pressures on the currency in 1998 were caused by the expectation of controls. However, the breadth and extent of these controls somewhat surprised investors once they were imposed.

Third, and relatedly, standstills risk international contagion. Contagion may occur either because investors start to expect that such standstills may be imposed on other countries or via the financial contagion channels that the literature has highlighted (common creditor effects, proxy hedging and cross-country hedging, proxy plays, increase in risk aversion of investors, portfolio adjustment effects). The Russian default and imposition of capital controls by Malaysia clearly produced a severe contagion effect in the summer-fall of 1998.

Fourth, partial standstills may not work. They may have to be extensive and widespread. A standstill on sovereign payments probably has to be comprehensive to be effective; otherwise, claims not included will be tempted to flee. Similarly, standstills on sovereign claims alone may not be enough, for several reasons. First, as in Korea and Indonesia, the claims of domestic banks and corporates can be the source of reserve loss and currency depreciation. Second, standstills on sovereign payments may not close the financing gap if private claims can also flee and the existence of a sovereign standstill leads private investors to worry that a broader stay of payments will soon be imposed on them.

Fifth, as a consequence of the point above, broad capital controls and exchange controls may have to be imposed that restrict the payment ability of private agents in the 
economy. ${ }^{57}$ Under fixed exchange rates, since all liquid claims -- even those in domestic currency -- can be turned into foreign assets, widespread capital controls may be necessary to reduce the pressure on official reserves. Under flexible rates, the same attempt of the private sector to turn domestic assets into foreign ones will lead to a sharp currency depreciation that is potentially very harmful if there are many foreign currency liabilities. Thus, again broad capital and exchange controls may be necessary to prevent an overshooting of the currency and other asset prices.

Sixth, standstills on payments of domestic private agents, especially corporates, are difficult to arrange; they effectively imply the imposition of capital and exchange controls. The controls may lead, as the experience of Indonesia shows, to perverse effects such as "asset stripping." It is one thing to impose controls to avoid a destabilizing rush to the exits; however, if such controls are used for strategic avoidance of sustainable debt payments and/or if they are used to strip the assets of the underlying firms, the effects may be perverse. Thus, while some form of standstill may make sense in countries where there is an efficient and functioning insolvency and corporate restructuring legal system, it can have perverse effects in countries where, because of inadequate institutions, corruption and archaic legal systems, creditors cannot seize firm assets and prevent asset stripping.

Seventh, formal standstills present complex legal issues. The main problem is whether a standstill can prevent litigation aimed at seizing the assets of the debtor. One solution would have been to provide such a power to the IMF, i.e. the power to sanction broad standstills. It is however agreed that providing such a power to the IMF would require amending Article VIII.2.b of the Funds Articles of Agreement. There is significant political resistance among the main Fund creditors to take a route that would provide the IMF with such an authority. All sorts of economic and institutional concerns have been expressed even though several influential voices have expressed support for such a change (including that of the former IMF Managing Director Camdessus and other official sources). ${ }^{58}$

In the absence of such an amendment, the issue becomes whether, in the presence of a standstill informally sanctioned by the IMF with a policy of lending into arrears, a court would provide a stay of litigation (prevent litigation aimed at seizing the assets of the debtor), especially if the debtor is cooperatively working to work out its payments with some of its creditors. While there is some limited legal precedent in the U.S. for courts imposing such stays, it is an open and complex issue whether such a stay could be successfully imposed as a temporary tool aimed at allowing an orderly workout. Also, while threat of litigation is an issue, occurrences of litigation in practice may be limited, especially because the ability of creditors to seize the assets of sovereign and private debtors in emerging markets is limited. Costs of litigation may effectively reduce the occurrences of such a problem.

\footnotetext{
${ }^{57}$ Malaysia is an example of the imposition of capital controls as way to prevent domestic residents capital flight and as a way to lock-in foreign investors trying to exit from their long local portfolio investments.

${ }^{58}$ In the absence of a legal mechanism to provide the IMF the power to sanction a standstill, debt suspensions by a sovereign or private sector entities (whether within or outside official PSI policies) are subject to litigation risk. For example, creditors accelerated their claims once Ecuador defaulted on its Bradies; but then they did not pursue legal action to enforce their claims.
} 
In spite of serious shortcomings with formal debt standstills, one cannot rule out the possibility that, in some circumstances, their benefits may outweigh their costs. Thus, while having formal rules that determine when a standstill may be introduced would be counterproductive if they triggered the rush to the exit that one wants to avoid in the first place, one cannot rule out their use in extreme situations. Some degree of constructive ambiguity may be helpful in this regard even if the uncertainty over whether, how, and how widespread a standstill is likely to be would in other respects be counterproductive. Temporary, targeted standstills in situations where a real commitment to policy reform exists (but is not fully credible to market participants) may be a useful part of the tool kit of crisis prevention and resolution. ${ }^{59}$ But such a tool needs to be used with extreme care to prevent consequences worse than the problems that it is aimed to cure.

\section{II.C.4. The G7 PSI framework and its application to bonded debt restructurings}

We discuss next the many aspects of the PSI official doctrine and practice as emerged in a number of recent case studies (Pakistan, Ukraine, Romania, Ecuador and Russia $^{60}$ ) of sovereign bonded debt restructurings. These recent episodes have involved countries that are small (non-systemic, with perhaps the exception of Russia) and where restructuring of bonded debt has become an element of the PSI in crisis resolution. Indeed, bonded debt restructuring is a relatively new, controversial and complex issue. Thus, we will discuss in detail the many issues that have emerged in applying PSI to the case of bonded debt and other similar securities. The official PSI doctrine can be characterized as a "case-by-case approach cum principles and tools". Note that such doctrine does not apply only to bonds but to overall claims of a debtor country (including bank claims). But the framework has been recently applied to many bonded debt restructuring cases.

\section{II.C.5. Collective Action Clauses and Voluntary Debt Exchanges}

While all of the recent episodes of sovereign bonded debt restructurings (Pakistan, Ukraine, Ecuador and Russia) have made a very limited use of against collective action clauses (CACs), before such bonded debt restructurings occurred - via voluntary exchange offers - strong arguments were made that bonded debt restructurings were not feasible without CACs such as collective representation mechanism for creditors, majority clauses to change the terms of bond contracts and sharing clauses. The arguments in favor and against collective action clauses (CACs) are by now familiar and the views on CACs of official creditors, private sector and debtors quite known. CACs were first proposed in the Rey Report as a way to facilitate the restructuring of bonded debt. Next, both the official sector in its many expressions of PSI doctrine (see Koln G7 Summit Architecture Communiqué) and academics (such as Eichengreen, Portes and many others) extolled their benefits. It was argued that the lack of such CACs would

\footnotetext{
${ }^{59}$ Korea's concerted rollover could be seen as such a targeted standstill in the context of a credible adjustment program while Malaysia's capital controls were much more coercive in their nature and implementation and not linked to an explicit policy adjustment plan.

60 Strictly speaking the Russian debt restructuring in 2000 was not a case of application of the PSI doctrine but resulted from the decision of the country to restructure again its old restructured London Club bank claims, the Prins (bonds issued in exchange for old 1997 London Club principal) and Ians (bonds issued in exchange for interest arrears on 1997 London Club debt) and the PDI (Past Due Interest) claims.
} 
make it very hard, if not impossible, to restructure bonds. Lack of collective representations mechanisms (such as bondholder committees, trustees and similar coordination mechanisms) would make it hard to coordinate actions of a multitude of dispersed bondholders and implement restructurings. Lack of majority clauses would require unanimity in the decision of changing the terms of the bond contract and hold a possible large majority of bondholder willing to restructure hostage to a possible miniscule minority of holdouts and vultures. Lack of sharing clauses - that require the sharing among all creditors of proceeding obtained by the litigation action of a subset of creditors - would open up room for disruptive litigation by a small group of litigious holdout creditors. ${ }^{6}$

The differences between bonds issues under UK law and those issued under New York law were also highlighted by many: the former effectively had collective representation, majority and sharing clauses (especially trustee bonds) while the latter did not. CACs (especially making them mandatory in international bonds) were first strongly resisted by the private sector under the logic that they would make restructuring too easy and would thus tip the bargaining power balance in favor of debtor with the risk of making defaults more frequent (strategic opportunistic defaults based on unwillingness to pay rather than inability to pay) and thus eventually undermining new debt flows to emerging markets. Borrowing countries too were concerned that such clauses would taint their reputations. Emerging market economies were wary of CACs being forcibly imposed on their debt contracts under the concern that spreads on such instruments would be higher. On the other hand, it was argued that spreads would rather be higher for instruments where restructuring was very hard, as the costs of necessary restructuring would be too high. Next, some academic research (Eichengreen and Mody, 2000a, $2000 \mathrm{~b}$ ) suggested that, actually, spreads for good credit countries are lower on bonds with CACs, though higher for poorer credit countries. ${ }^{62}$ Thus the benefits of reducing restructuring costs outweigh the penalty for possible opportunistic default for good credits. Academics (Eichengreen and Ruhl (2000), Eichengreen (2000) and Portes (2000)) also sharply criticized the ad-hockery of the case-by-case approach to PSI and argued that CACs would have provided a much more transparent and simple approach to all PSI problems.

In spite of these arguments in favor of CACs, recent experience with bonded debt restructurings suggests that, while CACs may be marginally helpful in facilitating such restructurings, their usefulness has been somewhat exaggerated. In all recent cases of bond restructurings (Pakistan, Ukraine, Russia and Ecuador) CACs have had a very marginal role. First, note that all these debt restructurings have occurred through unilateral "debt exchange offers" rather than via the formal use of CACs even in cases in which, as in Pakistan and Ukraine, the instruments included CACs. The use of unilateral debt exchange offers obviates the need for CACs as such an offer is voluntary and can be made regardless of the existence of majority or other collective action clauses. Thus, one

\footnotetext{
${ }^{61}$ Note that London Club debt - syndicated bank loans - implied implicit and explicit forms of collective action clauses: syndicated loans required the formation of creditor committees to represent the interests of creditor thus solving the collective action problem of coordinating creditors action; they included effective majority clauses as a majority of creditors could decide to restructure their claims while such actions not being necessarily binding on minority holdout banks; and, often, they included formal sharing clauses.

${ }^{62}$ Some recent work by Becker, Richards and Taicharoen (2000) finds even stronger results that CACs do not increase spreads for either better or worse credit issuers.
} 
can envision a system where debt exchanges are the norm and the CACs are not needed, nor used when available. CACs have been marginally helpful only in two cases: in Ukraine, where three out of four restructured instruments had CACs, such clauses allowed to "bind-in" ex-post holdout creditors after a vast majority of bondholders (over $90 \%$ ) had accepted the terms of the offer. Thus, they were used ex-post rather than exante to lock-in holdouts and prevent disruptive litigation. In the case of Pakistan, where restructured bonds all had CACs, such clauses were not used either ex-ante or ex-post. However, one could argue that they were somehow useful, as the possible threat of their use may have convinced some undecided creditors to accept the exchange offer. In Russia and Ecuador, debt restructurings were performed without any CACs as the underlying instrument did not have such clauses. But in the case of Ecuador, legal ways were found to dilute the litigation benefits of holdouts by the use of "exit consent" amendments. Thus, worse terms were "crammed down" on holdouts.

Thus, exchange offers have been the norm in bond restructurings so far, and CACs have not been used ex-ante to force the restructuring even when instruments including them were available. The question is thus why CACs did not turn out to be important and essential for successful restructurings in the way that had been suggested by many. ${ }^{63}$

One first answer is that exchange offers allow a restructuring of bonded debt even in the absence of any CACs. Litigation risk by holdouts is an issue to be considered in these cases but experience, so far, has been that such risk has been limited for reasons to be discussed in more detail below. So, exchange offers provide an effective alternative to CACs as a tool to implement bonded debt restructuring. Also, when available ex-ante, CACs can be used in a second round if an exchange offer were to fail; so they are an instrument of second resort rather than first resort in bond restructurings even when available.

Second, debtors and debt agents (such as trustees) are obviously wary of the idea of using collective representation clauses (such as creditor committees) and majority clauses because they are concerned that, even just calling a meeting of bondholder creditors may lead to undesirable outcomes. Such meetings may start a protracted negotiation process that may take too long, it may allow creditors to coordinate their decisions and take legal action against a debtor. In reality, no debtor or trustee would ever want to call a meeting of creditors unless previous market soundings and bilateral meeting with creditors have allowed these agents to figure out all the details of a possibly successful debt exchange offer. Thus, the model of debt exchanges without use of CACs where financial and legal advisors of the debtor make broad market soundings before the offer is launched to figure out which terms will maximize the probability of a successful offer - can avoid a potentially disruptive, long-delaying formal negotiation under creditor committees and via the use of CACs.

As suggested above, the model of "debt exchanges cum market soundings" has successfully worked so far in all bond restructuring cases and the role of CACs has only been either to provide a tool to "bind-in" holdouts ex-post or to threaten credibly their use in case an exchange offer does not work. This experience also suggest that academic critiques of the current PSI process as being ad-hoc and inferior to one with CACs turned out to a bit off the mark. CACs are only an empty shell that may or may not facilitate a

${ }^{63}$ See Eichengreen and Mody (2000b) for a recent defense of CACs. 
restructuring process. They are not, by themselves, a tool that provides ex-ante the answer to the complex set of questions (when, how, how much, which assets, which creditors, in which sequence) that have to be addressed when trying to restructure bonds. CACs do not provide ex-ante an easy tool through which these questions can be answered and solved in practice.

\section{II.C.6. Lessons from recent cases of bonded debt restructuring}

Bonded debt restructurings have occurred since 1999 as the direct outcome of the adoption of the new G-7 official PSI policy. Successful recent case studies include Pakistan (the first case of an application of the PSI policy as the Paris Club requested a restructuring of the private bonded claims of Pakistan on comparable terms to the restructuring of Paris Club claims), Ukraine (where the official sector nudged the country to restructure its sovereign bonded claims as an implicit condition for an IMF program) and Ecuador (where the official sector effectively sanctioned the country's decision to suspend payments on its Bradies in the face of an unsustainable external debt servicing path). In all these episodes, bonded debt restructuring was the effective outcome of the G7 policy to include bonded debt among claims to be restructured in situations where a country suffered of severe debt servicing problems. Russia successfully restructured its Prins and Ians but this was not formally part of the official PSI policy (but rather the result of the country's decision to restructure its liabilities). In Romania, PSI was attempted but eventually abandoned as the country made payment on maturing debt and then was unable to raise new money as required by the PSI components of its IMF program.

What are the lessons learned from these restructuring cases? While the sample of cases is limited (Ukraine, Ecuador, Pakistan, Russia and the failed attempt to impose PSI in Romania), one can suggests a number of tentative lessons.

First, debt exchanges (following extensive market soundings) are an operational alternative to the use of CACs or formal negotiations. In all these episodes CACs were not used ex-ante and the benefits of their existence was only the ex-post ability to "cram down" new terms on holdouts (as in Ukraine) or threaten their use (as in Pakistan). Even in the case of Ecuador, where there were no formal CACs in the old restructured instruments, the legal advisor found legal ways to "cram down" new terms on the holdouts to make the old bonds less appealing to the holdouts. Note that while Ecuador's bonds required unanimity to change payments terms, only a simple majority of $51 \%$ is required to change non-financial terms. Thus, "exit consent" clauses for those who accepted the deal were used to change the terms of the old bonds and make them less appealing to potential holdouts.

Second, all these deals provided mark-to-market gains to investors, as the terms of the deals were generous and included various sweeteners. Such sweeteners included financially favorable terms for creditors, informal upgrade in the seniority of the claims (in Russia), substantial upfront cash payments (Ukraine, Ecuador, Russia) and Brady collateral release (Ecuador). Indeed, some have argued that such deals were very generous to investors as they led to sharp gains evaluated at market prices relative to the pre-deal prices of the restructured bonds. Such gains were equivalent to over $20 \%$ for Ukraine, 32\% for Russian Prins (Principal Interest Notes) and 18\% for Russian Ians (Interest Accrual Notes), 3.5\% for Pakistani bonds and averaging over 30\% (based on the 
jump in the price of Brady Bonds, PDIs and Euros after the deal was announced) for the case of Ecuador.

Third, the reasons for the mark-to-market gains after the deals were announced are not fully clear. Some argue that the gains were due to the better than expected terms of the deals but, if a country's debt price depends on its ability to pay, it is not clear why unexpectedly generous terms would affect that price. Some explanations are: a better than expected deal signals something about the country's desire to do more adjustment than otherwise or more commitment to attempt to keep the new payment profile (as debt prices depend not only on the ability but also on the willingness to pay); the deal implies that the official bilateral creditors will bear a greater burden and the private sector will thus bear a smaller burden; the new instruments have or are perceived to have a greater seniority than other instruments, although the effect on the price is rational only if official creditors or other private creditors not in the bond deal are worse off as a consequence of the deal; the upfront cash in most of these deals (very significant in the Ecuador one as the Brady principal collateral was to be released to creditors) was a positive surprise that effectively gave senior payments treatment to investors who took the deal because cash today is much more valuable than a promise of payments down the line. If this is the case, whoever gets cash first does so at the expense of other future creditors (probably official ones) that are likely to be hurt by the deal. Thus, in most cases, the jump in price signals a deal that made some creditors better off, most likely at the expense of official creditors.

Fourth, it is not obvious that in all cases medium term debt sustainability has been restored. For cases such as Pakistan or Ukraine where the overall external debt burden was not unsustainable (i.e. the country was not insolvent), a restretching of payment terms allowed avoiding the payment humps and, subject to successful economic reform, the debt profile may become sustainable. Similarly, the default by Russia and semiforced restructuring of its external and domestic debt is likely to have put the country on a path of solvency. The same may not be said of the Ecuador deal whose terms were quite favorable to creditors. Even after the deal is concluded and even assuming the most optimistic scenarios for domestic adjustment, the country is likely to end up in the medium run with a debt to GDP ratio of around $100 \%$ and a debt to exports ratio and a debt to government revenues ratio that are well above the official HIPC (Highly Indebted Poor Countries) criteria for significant debt reduction. While the country's GDP does not allow it to qualify for HIPC relief, it is likely that the country will remain with debt ratios that are possibly unsustainable. Moreover, considering that the assumptions about fiscal adjustment and trade balance adjustment embedded in the IMF program are the most optimistic in terms of intensity of the country's policy adjustment, any slippage in performance will make such ratios much worse. One could argue that the country has only delayed for a few years its debt servicing problems and further debt restructurings will occur as the current debt profile keep the country insolvent.

Fifth, as the unsuccessful experience with PSI in Romania suggests, attempts to expect "new money" at below market rates from creditors as a form of PSI do not work if the country has lost market access and is allowed to make large debt payments that are coming to maturity. In 1999, Romania facing $\$ 720 \mathrm{~m}$ of payments was allowed by the IMF to use dwindling reserves to make such payments under the condition of raising $80 \%$ again in new money $(\$ 600 \mathrm{~m})$. Once the payment had occurred, the country lost any 
leverage (non payment threat) over creditors and the IMF and G7 lost their ability to nudge the country to an involvement of the private sector in sharing the burden of external debt adjustment. The subsequent attempts to raise $\$ 600$ were sequentially diluted in the face of the country's lack of market access; thus, eventually the IMF waived the PSI requirement in an obvious failure of implementing the PSI policy for that country.

The country then bore the consequences of its decision to make the payments on its external debt. The domestic adjustment was deeper than necessary with output falling in 1999 and early 2000 more than otherwise possible. The subsequent build-up of reserves in 2000 - earlier depleted by the large 1999 debt payments - was made at the cost of a substantial and sharp contraction of imports that was feasible only with a sharp contraction of output. Thus, the decision of the country not to restructure its external debt (that was sustainable in terms of its size but characterized by a very lumpy payments profile in the short run) was thus paid for with high real costs.

Stated official PSI doctrine is that the official sector should not "force" a country to get into a non-payment but should rather make clear to the country the consequences of continuing to pay when restructuring may be warranted according to the IMF. That is, the official PSI doctrine implies that continuing debt payments in these cases will imply a greater amount of domestic adjustment, not greater amounts of official support. In reality, however, debtor countries may still make decisions - continue payments - that eventually shift some of the debt burden on official bilateral creditors (Paris Club claims) or lead to greater than otherwise planned multilateral support. In practice, official bilateral and multilateral support may effectively grow ex-post in spite of ex-ante official statements to the contrary; or the terms of the IMF program may become effectively more lax to allow breathing space to the country.

Sixth, the official sector has indicated that bonded debt restructurings should be evaluated by the IMF to ensure that their terms are comparable to PC restructurings and consistent with medium term debt sustainability. This means for the IMF to assess the financial terms of these deals, the amount of upfront cash, the upgrade in seniority terms, the implications for medium term sustainability in deciding whether such deals is consistent with an IMF program. Note that the current system of incentives and the financial interests of advisors and debtors results in deals that turn to be financially beneficial to private creditors (as suggested by the jump in prices of the old debt in all recent exchanges) but may imply some burden shifting to official sector claims. Financial advisors are interested in generous deals because they maximize the probability of success (reduce "deal risk"), increase the fees and commissions that are conditional on a successful deal, and reduce the burden sharing burden for the buy-side of their firms (which hold the old bonds) while the sell-side is involved in underwriting and successfully placing the new bonds.

Thus, while the official doctrine suggests that the official sector should not "micromanage" debt restructuring, some systematic way to assess whether a deal is appropriate could be developed. It is true that the generosity of the deal may be at times required to ensure its success. In Ukraine, up to 100,000 creditors had to be convinced to accept the new bonds. In Ecuador, upfront cash, on top of the collateral release, was necessary to give incentives to PDI and Euro holders as such claims did not have collateral. Upgrade of seniority made the Russian Ians and Prins deal more palatable to creditors; et cetera. However, the issue that the IMF is mandated to assess is whether the 
terms of such deals are consistent with the overall adjustment program of the country and the medium term sustainability of its external debt.

Seventh, an alternative strategy has been to reduce the face value of debt as in Ecuador when the judgment was made that the country was insolvent. In other cases (Ukraine, Pakistan, Romania) where it was not clear whether the country was insolvent or rather facing illiquidity given the lumpy debt payments coming due, a rescheduling/restructuring rather than face value reduction was attempted. Even in such cases, the restructuring did imply some NPV reduction of the debt as interest rate and principal payments were rescheduled at rates that are below current market rates. Thus, some real debt reduction occurred even in cases in which face value reduction was not formally performed. As official bilateral claims are also rescheduled at rates that do not truly reflect repayment risk, PC debt is also subject to effective NPV reduction even if it is not formally written down. Comparable treatment of official bilateral and private claims is thus possible only in approximate terms as exact comparability is hard to define. In this regard, the Pakistan exchange appears as broadly comparable to the PC deal. Other cases (Russia, Ukraine, Ecuador) cannot be assessed as private claims rescheduling preceded Paris Club rescheduling.

Eighth, while a normal/standard restructuring sequence would have seen, as in the 1980s, an IMF program being followed by PC rescheduling of official claims followed by London Club rescheduling on comparable terms of private claims, only the Pakistan deal followed this sequence. In the other cases (Ukraine, Russia, Ecuador and, possibly Nigeria in the future), the IMF program was followed by debt exchanges of private claims with PC rescheduling to follow next. This reverse sequencing complicates the application of the comparability principle and may create strategic incentives in the private sector to "impose" "reverse comparability" or to stake ex-ante limits to the amount of private sector burden sharing. This reverse sequencing also confirms why a case by case approach to PSI was followed: simple rules, even for the sequencing process (such as a debt exchange to follow PC rescheduling), appeared to be difficult to implement given the limited and very recent case history in debt restructurings.

The reasons for the reverse sequencing in these episodes are varied: in Russia creditors may have tried to lock-in the amount of debt relief they were willing to provide before the Paris Club imposed comparable terms. But, since conditions for Russia (oil prices, current account, fiscal situation) improved significantly after the private deal, the Paris Club ended up offering a restructuring deal that did not imply any debt reduction, only generous restructuring. Thus, the private sector ended up complaining that they did more than the PC in going first with their deal. In Ukraine, delays and suspensions in the IMF program that delayed a Paris Club deal led investors to try to lock-in the best deal they could in spite of the lack of a PC deal. In Ecuador, the PC deal was repeatedly delayed given the time it took to negotiate an IMF program and, next, the country's inability to reach an agreement with its official bilateral creditors. Thus, in the summer of 2000 the country went ahead with its exchange offer in spite of the lack of a PC deal.

Ninth, differences among classes of creditors and conflict of interests among them have to be addressed. Short-term investors (such as highly leveraged institutions, hedge funds, vulture funds and other similar players) willing to buy distressed debt at low market prices have received hefty returns when, following exchange offers, the price of debt has rebounded. Longer term investors, such as real money funds, asset management 
firms and other investors with longer term horizons, have at times disposed of their holdings of distressed emerging market debt when restructuring became likely and prices of such debt have plunged. While having short-term investors who bought low and who obtained significant capital gains made the chances of a successful exchange deal more likely as such investors obtained significant mark to market gains, the losses incurred by more dedicated and longer horizon investors on their holdings of emerging market debt may reduce the core longer term demand for this class of debt and lead to lower flows and higher spreads for this category of debt. ${ }^{64}$ In general, official policy has tried to avoid having a negative effect on the longer-term prospects for emerging market debt. These conflicts of interest among creditors is also one of the reasons why the model of creditors committees may as a way to restructure debt may not work: such creditors may have very different interest and agendas and the collective action problem of finding a common creditor position may be as difficult as the problem of negotiating with the debtor. ${ }^{65}$ Also, serious issues about whether Chinese walls are too leaky in a world where mark-tomarket investors are buying and selling distressed debt may limit the possibility of having a representative creditor group; the actual composition of the holding group may change due to trading; also, some investors may be actually shorting the distressed debt rather than holding significant long position in the asset.

Tenth, litigation risk has been, so far, limited. Acceleration and cross-default occurred in the case of Ecuador but no legal action was taken by creditors to enforce their rights. ${ }^{66}$ The usual limits to litigation were at work: it is costly, it takes a long time, debtor assets are relatively hard to attach (even in cases, such as Nigeria, where the waiver of sovereign immunity is quite broad). Also, CACs have been successfully used for example in Ukraine - to bind-in holdouts, cram down new terms on such dissenting minorities and dilute their potential legal claims; even in cases, such as Ecuador, where the ex-ante availability of CACs was quite limited, creative legal clauses such as "exit consent clauses" have been created to achieve the same result. Also, the generous terms of recent exchange offers, together with the sweetener of significant upfront cash, has effectively helped to bribe possible holdouts.

\footnotetext{
${ }^{64}$ In this sense the interest of sell side agents in financial firms that manage the restructuring of debt may be at odds with the interest of buy side agents that manage dedicated emerging market portfolios for these firms. The impression that emerging market creditors and buy side interest are not fully represented is behind recent buy side efforts to be involved in the PSI debate and the creation of EMCA, the Emerging Markets Creditors Association.

${ }^{65}$ While in the 1980s creditors fond ways to solve this collective action problem, the situation today is somewhat different for several reasons: syndicated loans provided mechanism for collective representation of creditors; explicit and implicit majority and sharing clauses were available in those loan contracts while they are often absent in bond contracts; some financial institutions and individuals, namely Bill Rhodes of Citicorp, provided leadership to the group of creditors; the interest of the creditors were more homogeneous as they were all commercial banks while in the case of bonds you have a wide range of creditors with very different interests. Thus, while coordinating creditors may not be impossible in the case of bonds, it appears to be harder than in the 1980 s.

${ }^{66}$ The recent Peru-Elliott case where a "vulture" creditor - Elliott Associates - successfully sued Peru and was able to get payment in full for its pre-Brady claims may have changed the likelihood that creditors may successfully sovereign debtor claims. However, how far reaching this case will be is open to question as the legal issues were not tested in court given Peru's decision to pay rather than end up in technical default before a court decision on the case.
} 
In the absence of "exit consent" clauses in the new bonds or clauses that allow expost to bind in potential holdouts, the debtor has to decide how to deal with such holdouts. ${ }^{67}$ A credible threat not to provide holdouts with better terms than an those of the exchange offer is the only way a debtor can ensure that the offer will be accepted; otherwise many creditors would be better off waiting and trying their luck. Once the offer has been successfully accepted by the minimum threshold of the deal (a minimum 85\% acceptance rate for the Ecuador case for example), the debtor has to decide whether to keep its threat and risk litigation or whether it is better to appease the holdouts and pay them on terms that will lead them to settle. The former solution is a way to ensure that the ex-ante threat is not time inconsistent; otherwise, the game would unravel at the next debt restructuring episode. But buying off some marginal holdouts may, at times, be better for the debtor than engaging in costly and lengthy litigation.

The risks of litigation in future bonded restructuring cases should not, however, be underestimated. The recent Peru-Elliot case and the lessons learned by investors from previous restructuring cases may imply that creditors aggressively pursuing their claims may become more successful in the future. This litigation risk may thus turn out to be a serious issue if, for example, Argentina were to try to restructure its external debt on semi-coercive terms.

\section{II.C.7. Concluding Remarks on PSI}

The official G-7 and IMF PSI policy ("a case-by-case approach with principles, criteria, tools and guidelines") has been applied in the last few years to cases of bonded debt restructurings and cross border bank lines (cases such as Korea, Thailand, Indonesia, Brazil, Pakistan, Ecuador, Ukraine and Turkey and, indirectly, Russia and Argentina). The application of this policy has not led to the dire consequences and negative outcomes predicted by some a couple of years ago. Not only has the international capital market not been destroyed, but there is also little evidence so far that the flows of debt (and their pricing) to emerging market economies have been affected by this policy in ways that are jeopardizing long term flows to such economies. Moreover, a combination of official money and case-specific PSI minimized the cost of crises in a number of large systemic countries and thus supported their rapid resumption of economic growth. Also, moral hazard distortions have been somewhat reduced and there is evidence of healthy greater discrimination by creditors between better and worse sovereign debtors: average spreads do not seem to have been affected by the PSI policy while the distribution of such spreads appears to be more reflective of underlying credit/repayment risk. Finally, the G-7 PSI policy led to several cases of bonded debt restructuring that were successfully implemented even in the absence of an ex-ante use of collective action clauses.

The official PSI framework - as described in the relevant G-7 and IMF documents - provided a balance between the benefits of rules (to reduce uncertainty and unpredictability of policy) and the advantages of discretion to deal with each individual and complex case study. The overall balance of principles, criteria, consideration and tools in a PSI framework where a case-by-case approach has been shaped by basic principles and operational guidelines seems to have provided a tradeoff between rules and discretion. Maybe, over time, case history will allow the development of clearer rules

\footnotetext{
${ }^{67}$ See Bucheit and Gulati (2000) for a more detailed discussion of such exit consent clauses.
} 
even if, some degree of constructive ambiguity, may remain as a component of a efficient PSI regime.

Many complex issues are still to be addressed both in the "liquidity" cases and the "insolvency" cases. They are difficult, complex and not prone to simplistic answers and solutions. But the overall official PSI strategy in the 1990s ensured that the flows of capital to emerging markets continued to be the main source of finance to such countries while not being distorted by expectations of systematic bailouts of investors.

Such PSI policy may lead to endogenous financial engineering to create new classes of claims that are not as easily restructurable. In the 1990s, the emergence of interbank loans and bonded debt was partially - but only partially- the result of the bail-in of syndicated loans in the 1980s. Similarly, one can expect that new structured instruments embedded with complex derivative features may emerge as a strategy to avoid the bail-in of current debt instruments.

But there are limits to how this PSI-avoidance process can go. Eventually, a country's repayment of its debts depends more on its "ability to pay" than its "willingness to pay" as there are enforcement mechanisms (reputation and market discipline and punishment) to reduce the risk of opportunistic default. Thus, if a country will face debt servicing problem because of either an unsustainable debt burden or a profile of burden that is incompatible with short term liquidity resources, some rollover, restructuring, rescheduling or, at the extreme, reduction of the debt payments will become unavoidable, however sophisticated the new instruments are. ${ }^{68}$ Such instruments may shift the burden from some sheltered creditors to others (and the official sector is concerned that their result is not to shift the burden to the official sector) or they may just make the costs of

\footnotetext{
${ }^{68}$ When considering the issues of debt restructruings, one should be careful to distinguish between "inability to pay" versus "unwillingness to pay". As the theory of sovereign debt clearly suggests, the latter is an important issue. The latter phenomenon, i.e. strategic defaults and opportunistic non-payments, can be avoided via intertemporal and static market discipline. Punishments include trade sanctions, cutoff from lending in international capital markets and the output costs that creditors can inflict on defaulting sovereigns. Indeed, some punishment should be, and is, in the system to avoid strategic defaults. Some (Dooley (2000), however, go as far as arguing that the rationale behind PSI policy and IMF's lending into arrears policy is faulty as it will reduce the costs of strategic defaults. In Dooley's view, the output costs of default are the only meaningful punishment that prevents default in a world where the IMF or other agents cannot distinguish between non-payment due to inability to pay and non-payment due to unwillingness to pay. In his view, anything that reduces such debt renegotiation costs and make it easier to restructure sovereign debt (such as CACs, IMF lending into arrears, official sanctioning of defaults) will make the current system of international capital flow more inefficient and will cause a reduction in the flows of capital to emerging market. Dooley's basic point (there must be costs to opportunistic default) is sensible but the argument is taken to the extreme in ways that are not sensible. First, some countries will stop paying because of inability to pay; thus, in these cases it is in the interest of both the debtors and creditors to renegotiate the debt contract and restructure/rollover/reduce the debt. Making it very costly to do this restructuring will only hurt both creditors and debtors. Thus, a system where the output punishment is as high as possible and the renegotiation costs are as high as possible is not efficient nor optimal from a global welfare point of view. Second, in case of pure liquidity runs, there is a collective action problem that needs to be solved. Part of the solution (that is welfare beneficial to all) can be at times concerted rollovers of short term debts that are coming to maturity. Thus, a system where the costs of renegotiating debt claims and making reschedulings/rollovers is prohibitively high is also going to be welfare inferior to a system where renegotiation is possible. Thus, a sound system is one where the tradeoff between the need to avoid strategic default (via punishments) and the need to renegotiate efficiently contracts when liquidity runs or insolvency require so is balanced. A system where the costs of renegotiation are too high is inefficient and of no benefit to either debtors or creditors.
} 
renegotiating debt claims higher and thus make more difficult and more delayed such restructurings.

As long as the debt servicing problems derive from true inability to pay or avoidable liquidity humps that lead to liquidity runs, a system that makes it very hard or costly to restructure debts may not be efficient and may impose severe costs not only on debtors but also creditors. Creditors do not internalize the negative externalities or collective action effects of their unilateral attempts to stake seniority at the expense of other actors or the overall system. Thus the official sector has been concerned about the development and widespread use of instruments that provide effective seniority to some private claims relative to other private claims or official claims or that make it harder to restructure debts.

\section{The Architecture to Reform the International Architecture}

Just as we began our discussion of crisis management with a survey of the institutional arrangements by which it is done, so we precede our discussion of more fundamental reform of the international financial architecture with a survey of the additional institutions and fora in which these issues have been discussed.

\section{A. Halifax Summit and Rey Report}

A broad debate on the steps needed to strengthen the international financial system was already underway when the Mexican peso was devalued in December 1994. The ensuing peso crisis gave the debate considerable impetus and pertinence. The annual Summit of G-7 nations leaders in 1995 held in Halifax, Nova Scotia, initiated work in a number of areas. They called for additional study of means to prevent future crises and to promote their orderly resolution when they do occur. The Finance Ministers and Central Bank Governors of the G-10 countries were asked to review ideas. The G-10 group established a working party that submitted a report - informally known as the Rey Report, after its chairman - to the ministers and governors in May 1996.

The Rey Report noted recent changes that have altered the characteristics of currency and financial crises in emerging markets. It indicated that neither debtor countries nor their creditors should expect to be insulated from adverse financial consequences in the event of a crisis. It also called for better market-based procedures for the workout of debts when countries and firms are under financial distress. Specific reforms of bond contracts were proposed to encourage the cooperation and coordination of bondholders when the financial distress of a country or corporation requires the restructuring of the terms of a bond contract. It also suggested a review of IMF rules on "lending into arrears" in order to extend the scope of this IMF policy to include new forms of debt. Previously the power of the IMF had been used to support creditors' interests in the sense that it would cut off lending to any debtor that was not meeting its private debt service obligations. "Lending into arrears" would allow the IMF to continue lending, in certain unusual circumstances, to countries that had temporarily suspended debt-service payments but continued to maintain a cooperative approach towards their private creditors and to comply with IMF adjustment policies. 
A number of important innovations came out of this reform process: international standards for banking supervision, the so-called Basle core principles for banking supervision $)^{69}$; the development of international standards for making economic data publicly available, under the IMF's Special Data Dissemination Standard; an emergency financing mechanism in the IMF, the Supplemental Reserve Facility, to help members cope with sudden and disruptive loss of market confidence with financing significantly larger than traditional quotas; and the decision to expand the IMF's backup source of financing under the New Arrangements to Borrow. ${ }^{70}$

\section{B. G-22 Group and Reports}

Despite some progress in strengthening the system, the eruption of the Asian crisis in 1997 demonstrated the need for further efforts. In November 1997, on the occasion of the APEC (Asian Pacific Economic Cooperation) Leaders Summit in Vancouver, a number of Asian leaders proposed a meeting of finance ministers and central bank governors to discuss the crisis and broader issues regarding the functioning of the international monetary system. They suggested that the meeting be global, that is, that it should include emerging-market countries, and not just the usual small group of major industrialized countries. U.S. President Clinton responded by calling on Secretary Rubin and Chairman Greenspan to convene such a meeting. Finance ministers and central bank governors from twenty-two systemically significant countries (informally dubbed the G-22) accordingly gathered in Washington on April 16 to explore ways to reform the international financial system that could help reduce the frequency and severity of crises. ${ }^{71}$ Ministers and governors created three working groups to consider: measures to increase transparency and openness; potential reforms to strengthen domestic financial systems; and mechanisms to facilitate appropriate burden sharing between the official and private sector in times of crisis.

The U.S was strongly supportive of the creation of the G-22 group, as it included systemically important emerging market economies while other G-7 members, especially the Europeans, remained slightly wary of a new group that might crowd out some functions traditionally performed by other groups or institutions where they had more influence and leverage (the IMF Executive Board, the Interim Committee, the G-10). The three working groups of the G-22 presented their reports in October 1998, on the occasion of the annual meetings of the IMF and World Bank.

The report of the G-22 working group on "transparency and accountability" recommended that national authorities publish timely, accurate and comprehensive information on the external liabilities of private financial and corporate sectors as well as their own foreign exchange positions; it recommended adherence to existing international standards for transparency; it called for better monitoring of countries' compliance with

\footnotetext{
${ }^{69}$ Goldstein (1997).

${ }^{70}$ Twenty-five potential participants to the NAB agreed to make loans to the IMF when supplementary resources are needed to forestall or cope with an impairment of the international monetary system, or to deal with an exceptional situation that poses a threat to the stability of the system. The 25 include many outside the traditional circle of member countries of the G-10 or of the original General Arrangements to Borrow.

${ }^{71}$ The group ended up being effectively composed of 26 members, the usual size creep in these types of international groupings.
} 
such standards, including through IMF reporting on countries' adherence to internationally recognized standards. It also recommended that the potential for greater transparency of the positions of investment banks, hedge funds and institutional investors should be examined. Finally, the IMF and other international financial institutions (IFIs) were called upon to be more open and transparent. Unnecessary secrecy was deemed particularly inappropriate in institutions telling others to be more transparent.

As weaknesses in the financial sector were at the core of the Asian and global crisis of 1997-98, the report of the G-22 working group on "strengthening financial systems" included the following recommendations: strong prudential regulation and supervision of banks and other financial institutions; design of explicit and effective deposit insurance schemes to protect bank depositors; design and implementation of bankruptcy and foreclosure laws for insolvent firms; development of liquid and deep financial markets, especially markets in securities (bonds and equities); national implementation of the Basle core principles of banking supervision and of the objectives and principles of securities regulation set by IOSCO (the International Organization of Securities Commissions); coordination and cooperation among international organizations and international supervisory entities in strengthening financial systems; technical assistance for and training of government officials and regulators; improvement of corporate governance in both the financial and non-financial sectors, so that investment decisions respond to market signals rather than to personal relationships; implementation of efficient insolvency and debtor-creditor regimes that would facilitate workouts for corporations in financial distress. These may include procedures for systemic bank and corporate restructuring and debt workouts.

The report of the G-22 working group on international financial crises identified policies that could help promote the orderly resolution of future crises, including both official assistance and policies and procedures that could facilitate appropriate private sector involvement (PSI) in crisis resolution. The work of this working group was a continuation of the development of official PSI policy that started with the Rey Report and continued in 1999 and 2000 with the development of the G-7 framework for PSI (see Section II for details).

At two subsequent meetings in March and April 1999, an enlarged group, the G33 discussed issues related to reform of the global economy and international financial system. The experience with the ad-hoc G-22 and G-33 groups, which led to a broad dialogue on many important aspects of the international architecture reform, next led the U.S. to suggest in 1999 that a more permanent group, including advanced economies and systemically important emerging economies, the G-20, be created.

\section{The Road to the Koln and Kyushu-Okinawa Summits of the G-7}

The work of the G-22 group laid the foundation of subsequent work on reforming the "international financial architecture" (a term first introduced by U.S. Treasury Secretary Rubin). The G-7 took the main lead on this project but emerging markets and other advanced economies were involved in the dialogue via the G-22, G-33 and G-10 groupings.

In the fall of 1998, the Asian crisis became global with the collapse of Russia in August 1998, the contagious effects of this crisis to other emerging markets (Brazil and 
the rest of Latin America), the near collapse of LTCM and the ensuing liquidity seizure in the capital markets of the U.S. and other advanced economies. By October 1998, the risk of a global financial meltdown had become significantly greater. The U.S. and the other G7 responded to this threat through a series of joint initiatives, outlined in the October 30, 1998 statement of the G7 Finance Ministers and Central Bank Governors. The G7 committed to a number of reforms consistent with the recommendations of the G22 working groups as well as a great deal of additional work on architecture reform in areas previously not dealt with. At the same time, a series of uncoordinated reductions in interest rates in the fall of 1998 by the U.S. Fed, other G-7 central banks and a larger number of other monetary authorities helped to restore liquidity in financial markets, reduce the panic that had enveloped financial markets following Russia and LTCM and restore confidence of investors in the stability of the international financial system.

The G-7 effort to reform the international financial architecture took momentum in the winter of 1998 and spring of 1999. The G-7 agreed to come up with a specific architecture reform by the time of the G-7 Koln Summit in June 1998. This cooperative efforts led to the Report of the G-7 Finance Ministers to the Koln Economic Summit ("Strengthening the International Financial Architecture") where a broad range of proposals to strengthen crisis-prevention and crisis-resolution were agreed.

The G-7 agreed to measures to strengthen and reform the international financial institutions (the IFIs, i.e., the IMF and Multilateral Development Banks); enhance transparency and promoting best practices (specifically strengthen financial regulation in industrial countries); and strengthen macroeconomic policies and financial systems in emerging markets. The last included appropriate choice of exchange rate regimes for emerging markets, ways to improve their financial systems, ways to ensure that the benefits of international capital flows are maximized, and appropriate management of external and domestic debt to reduce liquidity and balance sheet risks.

The G-7 also agreed on policies to improve crisis prevention and management. The latter included a formal framework for private sector involvement in crisis resolution that became the core of the G-7 PSI doctrine. This doctrine can be described as a case-bycase approach to PSI constrained by principles, considerations and tools.

Following in part the private sector demands for greater transparency, clarity and rules and to provide clearer guidelines to the IMF, the case-by-case approach to PSI was refined in April 2000 through a set of "operational guidelines" providing more details on the process and substance of PSI. These operational guidelines were agreed by the G-7 at the Ministerial meeting around the IMF/World Bank spring meeting and were later formally adopted in the G7 Finance Ministers and Central Bank Governors communiqué prepared for the July 2000 G-7 summit.

The July 2000 Kyushu-Okinawa G-7 Summit (preceded by the meeting of the G-7 Finance Ministers at Fukuoka that produced the Report on "Strengthening the International Financial Architecture" from G7 Finance Ministers to the Heads of State and Government) also saw the emergence of further G-7 consensus on two other major issues. First, on how to reform the IMF and Multilateral Development Banks. The consensus on IMF reform at Fukuoka fleshed out the agreements previously reached by the G-7 at the time of the IMF Spring meetings in April 2000. Operationalization of the agreements on IMF reform (especially the reform of facilities approved by the IMF Board) was achieved by September 2000 in coincidence with the Fall Annual meetings of 
the IMF/World Bank in Prague (see Section V.D for details). Second, the G-7 also agreed on policies towards HLIs (Highly Leveraged Institutions), Capital Flows, and OFCs (Offshore Financial Centers) that were supportive of the recommendations of the working groups of the Financial Stability Forum (see subsection D below for details).

\section{New Groups}

\section{III.D. 1. The International Monetary and Financial Committee (IMFC)}

The International Monetary and Financial Committee (IMFC) came into being on September 30, 1999, when the IMF's Board of Governors approved a proposal of the IMF Executive Board to transform the Interim Committee into the IMFC and strengthening its role as the advisory committee of the Board of Governors; the Committee usually meets twice a year.

"Like the Interim Committee, the IMFC has the responsibility of advising, and reporting to, the Board of Governors on matters relating to the Board of Governors' functions in supervising the management and adaptation of the international monetary and financial system, including the continuing operation of the adjustment process, and in this connection reviewing developments in global liquidity and the transfer of resources to developing countries; considering proposals by the Executive Board to amend the Articles or Agreement; and dealing with disturbances that might threaten the system."72

The creation of the IMFC was the result of an elaborate diplomatic dialogue between the United States and Europe (especially France) on which international bodies to strengthen. The U.S. supported trying to involve more systemically-important emerging markets in the dialogue on international financial issues that eventually led to the creation of the G-20. The Europeans, especially France, instead wanted to strengthen existing institutions and pushed for turning the IMF Interim Committee into a stronger and permanent political body that would give guidance to the IMF Board on major policy issues. The creation of the IMFC turned the longstanding previously-"temporary" Interim Committee (IC) into a permanent one. However, the functions and roles of the IMFC effectively ended up being equivalent, with minor nuances, to those of the previous IC; certainly, the new IMFC, currently headed by the UK Chancellor Gordon Brown, does not have the broad political mandate and power that the French wanted it to have.

\section{II.D.2. The $G-20$}

The G-20 was created at the urging of the US, out of a desire for a forum where important emerging market economies would have a voice and participate in a dialogue on global financial issues. The positive experience with the G-22 (and G-33) process suggested a need for better involving these emerging markets.

The finance ministers of the Group of Seven (G-7) leading industrialized nations announced the creation of the Group of Twenty (G-20) in September 1999. This new international forum of finance ministers and central bank governors represents 19

\footnotetext{
72 The Committee, whose members are Governors of the IMF, reflects the composition of the IMF's Executive Board: each member country that appoints, and each group that elects, an Executive Director, appoints a member of the Committee, which, like the Executive Board, has 24 members. The IMFC is currently chaired by Gordon Brown, the British Chancellor of the Exchequer.
} 
countries, the European Union and the Bretton Woods Institutions (the International Monetary Fund and the World Bank). ${ }^{73}$ The mandate of the G-20 is to promote discussion, and studies and reviews policy issues among industrialized countries and emerging markets with a view to promoting international financial stability. ${ }^{74}$

The first Ministerial meeting of the G-20 was held in Berlin in December 1999 and the second was scheduled to take place in Montreal in October 2000. So far, the G-20 has been mostly forum for dialogue (some belittlingly call it a "talk shop") on exchange rate regimes, national balance sheets management and prudent debt management, PSI and global financial issues, financial sector regulation and supervision, international codes and standards. In between Ministerial meetings, the G-20 work in 2000 continued at the deputies level with a broad dialogue and papers on three crucial issues in international financial architecture: exchange rate regimes; national balance sheets and vulnerabilities; and private sector involvement in crisis resolution.

The October 2000 meeting of the G-20 reviewed the global economic outlook, the challenges posed by globalization, issues related financial crime and money laundering and discussed ways to make the world less vulnerable to financial crises, especially the issues discussed at the Deputies level. The G-20 Finance Ministers and Central Bank Governors agreed on a series of measures aimed at "Reducing Vulnerability to Financial Crises" that included appropriate exchange rate regimes (supporting consistent and credible exchange rate regimes while not endorsing corner solutions to exchange rates), prudent liability management, private sector involvement in crisis prevention and resolution (endorsing the principles and tools agreed by the IMF's IMFC at the 2000 Spring and Annual meetings) and implementation of international standards and codes.

In the view of some, the G-20 should become over time an institution with greater importance and influence than the G-7 because of being more representative of systemically important countries. While over time, the views of important emerging market economies might be more represented in international affairs, it is unlikely that in the short run the leadership role of the G7 will be reduced. But the G2-0 is a forum where a serious dialogue between advanced economies and emerging markets can be pursued. ${ }^{75}$

\section{II.D.3. The Financial Stability Forum (FSF)}

The Asian and global financial crisis suggested shortcomings to the pattern of isolated national supervision and regulation of financial institutions in a world where such institutions operate globally and financial markets are becoming increasingly

\footnotetext{
${ }^{73}$ Member countries include: Argentina, Australia, Brazil, Canada, China, France, Germany, India, Indonesia, Italy, Japan, Mexico, Russia, Saudi Arabia, South Africa, South Korea, Turkey, the United Kingdom, the United States and the European Union. The Managing Director of the IMF and the President of the World Bank, as well as the Chairpersons of the International Monetary and Financial Committee and Development Committee of the IMF and World Bank, participate fully in the discussions. Finance Minister Paul Martin of Canada was selected to be the inaugural chairperson of the G-20. The first meeting was chaired by Minister Martin in Berlin in December 1999. The second meeting was scheduled to take place in Montreal in October 2000.

${ }^{74}$ Finance Minister Paul Martin of Canada was selected to be the inaugural chairperson of the G-20.

${ }^{75}$ Some, for example de Brouwer (2000), go as far as suggesting that new international groups such as the G20 may replace or augment the policy function of the IMF. In this view, the IMF is too a bureaucratic orginanization and new international groups do not have the additional layer of interference in international policymaking. These are, however, minority views.
} 
integrated. While proposals for international financial regulation (such as Kaufman's global super-regulator, discussed in Part VI) are regarded as unrealistic, greater international coordination of policies of financial regulation and supervision has been deemed most useful and necessary. This need for coordination led to the creation in 1999 of the Financial Stability Forum (FSF).

In the winter of 1998 Bundesbank President Tietmeyer worked on a proposal to establish a Financial Stability Forum to improve policy coordination among national financial authorities, the international financial institutions, and international regulatory bodies to promote international financial stability. Another aspect of the FSF is that its membership has been broadened beyond the G-7 industrial countries and now includes eleven advanced economies (G-7 plus Australia, Hong Kong, Singapore, and the Netherlands); additional emerging market economies (such as Malaysia) participate in the various working groups of the Forum.

The FSF was first convened in April 1999 "to promote international financial stability through information exchange and international co-operation in financial supervision and surveillance. The Forum brings together on a regular basis national authorities responsible for financial stability in significant international financial centers, international financial institutions, sector-specific international groupings of regulators and supervisors, and committees of central bank experts. The FSF seeks to co-ordinate the efforts of these various bodies in order to promote international financial stability, improve the functioning of markets, and reduce systemic risk." The Forum is chaired by Andrew Crockett, General Manager of the Bank for International Settlements, in his personal capacity.

Initially, the FSF formed three working groups on capital flows, offshore financial centers and highly leveraged institutions. They presented their reports and recommendations in the spring of 2000.

The working group on capital flows recommended that national authorities put in place a risk management framework, or national balance sheet, for monitoring and assessing the risks faced by their economies arising from large and volatile capital flows. The group, recognizing the vulnerabilities associated with sovereign debt that is too short term, recommended that the IMF and World Bank develop a set of guidelines for sound practices in sovereign debt and liquidity management, which they are now doing. The guidelines include, for example, addressing gaps in available statistics, encouraging greater transparency, and eliminating laws and regulations that inadvertently encourage imprudent behavior. The group also pointed to other important ways in which national authorities and international bodies should support the process of addressing the national balance sheet approach to assessing the risks from capital flows.

The working group on offshore financial centers (OFCs) concluded that it was essential for offshore financial centers to implement international standards as soon as possible, especially in the areas of regulation and supervision, disclosure and information sharing, and anti-money laundering, and that such implementation would help address concerns about some OFCs. The group's recommendations spell out a process for assessing OFCs' adherence to international standards, identify standards for priority implementation and assessment, and propose a menu of incentives that could be applied to enhance their adherence to international standards. The publication by the FSF in the summer of 2000 of a "black list" of 25 financial centers that have poor supervision 
and are not internationally cooperative was based on the view that OFCs that are unable or unwilling to adhere to internationally accepted standards for supervision, co-operation, and information sharing create a potential systemic threat to global financial stability. The importance of the issue of OFCs was stressed by the G-7 Finance Ministers Report at the Fukuoka Summit. The G7 and FSF consensus has put strong heat on these "deviant" jurisdictions to improve their supervision and be more cooperative.

The HLI working group considered issues of systemic risk and market dynamic in small and medium sized economies. Details on the progress in this HLI area are presented in Section IV.C.

The FSF also began discussion of implementation of international standards to strengthen financial systems. The Forum agreed that attention should focus on 12 key international standards, which will be highlighted in a Compendium of Standards. Also, a study group on deposit insurance has made some progress and has asked the group to consult widely in the development of international guidance for deposit insurance arrangements.

In the future, it is likely that the FSF work will be less focused on policy recommendations and more of a talk shop about issues, providing discussion papers on matters of policy relevance. Also, the existence of the FSF has lead to some healthy degree of competition, in addition to cooperation and dialogue, among international agencies such as the IMF and the Basle Committee on Banking Supervision. For example, the work by the FSF on implementation of international codes and standards has led the IMF to renewed efforts to lead the way on these issues, as exemplified by its work on the Report on the Observance of Standards and Codes (ROSC).

\section{Reforms for Better Crisis Prevention}

Two of the most important pillars of the international financial architecture are exchange rate regimes (how flexible should they be?) and capital account regimes (how open should they be?). The attitudes of the G-7 countries on these issues are important. And reform of the world monetary system that was fundamental enough to qualify as a "new architecture" or a "new Bretton Woods" would properly include these questions. But these two topics fall inside the mandate of another of the chapters for this conference. $^{76}$ In this part of our chapter, we look at other reforms to help prevent crises.

One of the central elements of architecture reform has been designing better policies for crisis prevention. While crisis resolution is also central to the reform process, prevention is even more important to the extent that stronger policies and institutions can reduce the probability that financial crises will occur in the first place.

The efforts of the G-7 and other international institutions and bodies to design policies for better crisis prevention have been comprehensive. Their broad scope includes a vast series of initiatives and actions:

1. Transparency and accountability of emerging markets, their economic agents, and the international financial institutions

${ }^{76}$ Edwards (2000). 
(such as the IMF); and greater disclosure and reporting by banks and other financial institutions in advanced economies.

2. Greater attention given by the IMF and emerging markets to indicators of vulnerability to crises.

3. Greater attention to national balance sheet analysis and risk management, especially liquidity and balance sheet risks.

4. Optimal public debt management to reduce liquidity risk, exchange rate risk and balance sheet risk.

5. Prudential regulation and supervision of financial systems in emerging markets.

6. Policies to maximize the benefits of international capital flows.

7. Work on highly leveraged institutions (including hedge funds).

8. Work on offshore financial centers, OFCs (see section III.D).

9. Reform of the Basle capital adequacy standards.

10. Private contingent credit lines.

11. Implementation of international standards and codes.

12. Better governance of the financial and corporate systems.

It is not possible to discuss in great detail all the initiatives, programs and actions in the above areas. Instead we will concentrate on some of the main issues and open questions.

\section{A. Transparency}

There has been a lot of support for greater transparency by emerging markets economies and international financial institutions. The arguments are familiar: greater information, transparency and openness on the part of emerging markets, IFIs and even advanced economies institutions will allow private investors and the entire international financial community to better assess risks, reduce the chances of irrational rushes to the exits and improve the efficiency of international capital markets. It is usually said that transparency is like motherhood and apple pie, i.e., everyone likes it with the caveat that it may not be enough by themselves to prevent crises.

Things are however more complicated. Resistance to greater transparency is still widespread among emerging market economies. For example, some resistance has been presented to the new SDDS (Special Data Dissemination Standard) reserve templates (i.e. the provision within the IMF's SDDS of much more detailed data about the foreign exchange reserves of member countries) and to the effort to expand the SDDS to external debt data disaggregated by economic sector, maturity and currency composition. Many emerging markets still do not allow the publication of their IMF Article IV reports. Many countries still resist or have not gone through the ROSC (Report on the Observance of Standards and Codes) exercise. The IMF reports on the state of the banking and financial systems of its member countries (the Financial System Stability Assessments) are still in experimental stage and many countries oppose their publication. The IMF effort to 
develop "macro-financial prudential indicators" (that are more indicators of the health of the financial system than macro vulnerability) is somewhat stalled as many data on the financial sector soundness are not available and there is some political resistance by emerging markets to such assessment. Progress on developing indicators of vulnerability to liquidity and currency risk is positive (as more country documents provide assessments and measures of such vulnerabilities) but still incomplete; regular publication by the IMF of vulnerabilities indicators for emerging markets may a useful addition to this effort. And the February 2001 decision by the IMF to create a new International Capital Markets Department will support - among other functions of this new department - the monitoring of vulnerabilities in emerging market economies.

Thus, while a lot of progress has been made in the area of transparency and the IMF has been quite open to the reforms in this area of crisis prevention, still a lot of work needs to be done. One issue that still remains somewhat sticky and is a matter of concern to IMF staff is whether greater transparency (such as, for example, publication of Article IV consultations reports) may lead emerging market officials to be less open, frank and willing to share confidential information with IMF missions. Some have argued that the great emphasis on transparency has already had some chilling effect on IMF interactions with such officials. The issue is similar to the question how much bank and financial regulators should disclose of the information they have access to on the health of financial institutions. On the one hand, good supervision and regulation requires, at times, discretion and withholding of some information. On the other hand, financial markets need as much information as possible to make rational assessment of the true valuations of firms and financial institutions. Thus, in general, more information and transparency may be useful, but there are some limits to how far one could go in this area.

\section{B. BIS capital adequacy standards and their implication for crisis prevention}

Many issues in the reform of the Basle Capital Accord, which set guidelines for minimum capital levels to be maintained by countries' banks, are open. The initial draft of the consultative paper on how to reform the Accord was issued in June 1999 and the comment period had closed by March 2000. Two of the major proposals in the initial consultative paper were to tie capital weights to ratings by credit rating agencies and to use banks' internal credit ratings as a basis for the capital weights.

The reform of the Capital Accord is a most complex issue with many dimensions. One question is the relative importance to be given to three pillars: market discipline, supervisory review and capital regulation in the capital adequacy framework. But some of the sticking points in the debate on this reform have an important bearing for the specific issue of international crisis prevention. First, if you allow some banks to use their internal models of risk, what criteria do you use to decide which banks, and in what countries, as opposed to requiring on a more traditional standardized approach? For example, Europeans believe that most of their banks should qualify to use internal models of risk, but some observers, especially in the U.S., are skeptical that many European banks have the capacity. So, it is important to set benchmarks on what institutions are going to be allowed to use such models.

Second, what is the best way to build compliance with international codes and standards into the capital adequacy ratios? The FSF and other official institutions 
(especially finance ministries) support this approach as a way to give incentives to emerging markets to implement such codes and standards. But there is resistance on the part of bank regulators and the Basle Committee; in their view bank capital charges should not be used as a tool to achieve goals not directly related to appropriate risk assessment. But compliance with standards and codes does affect capital risk of financial institutions. Also there is some concern that bank regulators look at the issue of the capital standards in too narrow terms (the risk of individual banks) and do not appreciate enough the importance of systemic risk. Incentives to implement codes and standards may reduce financial contagion, the risk of systemic banking crises and the likelihood of systemic risk to the international financial system.

The Basel Committee issued a new draft of the consultative paper in January 2001, seeking comments from interested parties by May 2001. The initial draft proposal of linking banks' capital to ratings produced by external credit-rating agencies was dropped in the new draft. Also, while the January 2001 draft reaffirmed the support for internal risk models, concerns have been expressed that reliance on internal ratings may aggravate economic cycles, because loan standards may be relaxed during economic booms and tightened during recessions.

\section{Highly Leveraged Institutions and Hedge Funds}

Concerns about the role of highly leveraged institutions (HLIs), and hedge funds in particular, emerged in the wake of the Asian crisis for two reasons. First, the collapse of a large hedge fund - Long Term Capital Management (LTCM) - provides a vivid example of how high leverage contributes to systemic risk. Second, actions of some hedge funds in small and medium sized economies led to concerns about the aggressive trade practices of such funds and allegations of market manipulation. Hong Kong and Australia, in particular, argued that hedge funds had engaged in manipulative practices in their foreign exchange and other asset markets. Accordingly, one of the three initial working groups of the Financial Stability Forum (FSF), set up in the spring of 1999, addressed the question of the role of HLIs in systemic risk and market dynamics in small and medium sized economies.

Regarding the issue of systemic risk, the recommendations of the report of this working group parallel, with some differences, the eight recommendation of the report of the U.S. President's Working Group on Capital Markets (April 1999). It was agreed to emphasize indirect regulation of hedge funds, for the time being, and to avoid direct regulation. ${ }^{77}$ The recommendations included measures aimed at better risk management by HLIs and their counterparties (better credit assessments, better exposure measurement, establishment of credit limits, collateral management techniques), better creditor oversight (greater intensity on firms that are falling short, periodic reaffirmation of compliance with sound practices), and enhanced public disclosure and reporting to authorities.

\footnotetext{
${ }^{77}$ Options other than indirect regulation, such as a credit register and direct regulation, while rejected for the time being, will be re-considered by the FSF if implementation of the other recommendations proves ineffective.
} 
Regarding market dynamics, the HLI working group ${ }^{78}$ formed a subgroup that performed a study of the role of HLIs (both hedge funds and proprietary desks) in the currency turmoil experienced by six economies (Hong Kong, Australia, New Zealand, South Africa, Singapore and Malaysia) during 1998. The results of this study ${ }^{79}$ were somewhat different from those of the IMF study on the role of hedge funds in the currency turmoil in East Asia in 1997. The latter considered the role of hedge funds only in the initial stages of the crisis (up to November 1997), while the FSF's HLI market dynamics study group considered the continuing turmoil in the six small and medium sized economies under study during1998. Whereas the IMF study had come to the conclusion that hedge funds had played only a minor role (at the back of the herding pack rather than the leaders of it), the HLI study group found a more significant role of hedge funds and proprietary desks (which trade for their own account) of international financial firms in the latter episodes of turmoil in 1998 in these six economies studied. For example, circumstantial evidence was found of some aggressive trade practices (rumors, false information, placing large trades at less liquid times of the day, such as lunch). ${ }^{80}$

Although it was hard to reach a consensus on controversial issues of market destabilization and manipulation, the group concluded that:

- From time to time, HLIs may establish large and concentrated positions in small and medium-sized markets. When this is the case, HLIs have the potential to influence market dynamics, especially in periods of market turmoil.

- The judgment as to whether HLI positions are destabilizing has to be made on a case-by-case basis. Some members of the group took the position that the largest hedge funds exacerbated the macroeconomic difficulties of several economies in 1998 and even manipulated their currencies, while others believe that, provided the economic fundamentals are strong, hedge funds are unlikely to present a threat.

The HLI report made a series of recommendations to address the issue of market dynamics even though most of its policy recommendations were in the area of systemic risk. First, the report noted that enhanced risk management practices could also address some of the concerns raised by emerging markets by constraining excessive leverage. Second, the HLI group also noted that where trading takes place on organized exchanges, requiring market participants to report to regulators, and possibly requiring position limits as well, could alleviate some of the pressures caused by large and concentrated positions. Third, the FSF recommended that market participants themselves articulate guidelines for market conduct in the area of foreign exchange trading. These market guidelines would address the concerns of smaller and medium sized economies about the aggressive trading practices that might have contributed to exacerbating market pressures in period of market turmoil.

\footnotetext{
${ }^{78}$ The HLI group included officials from finance ministries, central banks and financial regulatory agencies of major industrial countries and some emerging market economies.

79 The report of this group ("Report of the Market Dynamics Study Group") can be found at: http://www.fsforum.org/Reports/RepHLI.html.

${ }^{80}$ For a recent theoretical and empirical study of the role of large players in currency crises, see Corsetti, Pesenti and Roubini (2001).
} 
Progress in implementing the President's Working Group recommendations, and those of the HLI working group, has been slow, as they require both regulatory and legislative actions that have been hard to achieve. Some who had favored the idea of direct regulation but accepted the indirect regulation approach hoping for a rapid implementation of the recommendations, feel frustrated that more rapid progress has not been made in implementing measures to reduce the risks posed by hedge funds and other HLIs; several of the eight recommendations of the President's Working Group remain to be implemented.

However, the nature of the hedge fund industry has changed rapidly, with some significant deleveraging occurring over time. Some of major hedge fund players have effectively closed shop, especially those (LTCM, the Tiger funds, the Soros funds) that were alleged to be behind the episodes of systemic risk and destabilizing market dynamics. Emphasis on the role of hedge funds may be now misplaced as they do not play the same leading role that they did a few years ago. The size of the assets managed by hedge funds is small (less than $\$ 1$ trillion), even after controlling for leverage, relative to that of the mutual fund or insurance sectors, which each manage more the $\$ 5$ trillion of assets. While such players are regulated and may be less leveraged than other players, they command large financial resources and their investment decisions can significantly affect currencies and asset prices. Thus, such new players may emerge as more relevant for future systemic crises and the efforts to avoid them. Moreover, recent evidence about reduced liquidity in financial markets (the forex market and other G-7 financial markets) and the concerns expressed about them may have to do with the disappearance of large leveraged players in these markets. As some financial institutions have closed - or scaled down the activities - of their proprietary desks and as some large macro hedge funds have closed shop or significantly reduced the size of their positions, capital and liquidity available for market making and contrarian positions may have fallen, thus leading to reduced liquidity and greater asset price volatility.

\section{Private Contingent Credit Lines.}

Another possible tool for emerging market countries to prevent crises is facilities for contingent credit lines from private international banks. These could take two forms, either the contingent repo facilities that Argentina has or loan facilities secured with collateral as suggested by Feldstein (1999a). The issue of collateralized facilities relates to the question of credit enhancements, an issue discussed in part V .4. below. Private contingent credit lines (CCLs) like those of Argentina were also set up in Mexico and Indonesia. While private CCLs may become an element of the toolkit of crisis prevention tools, one could be somewhat skeptical of their overall effectiveness for a number of reasons:

a) It is not obvious whether these facilities provide additional financing resources to an emerging market in periods of pressure and turmoil. The creditors may want to reduce risk when such pressures emerge and can always reduce their exposure to the debtor in a number of ways, either through direct reduction of other long positions in the country or through the use of financial derivatives to hedge the country risk and exposure. 
b) The experience with private CCLs has been so far disappointing. They were unable to stem the crisis in Indonesia, and were not even used, probably because of their small size relative to the amount of capital flight.

c) Mexico drew on its facility in 1999 when the global turmoil spread to its economy. But since the borrowing rate was well below the higher spreads on Mexican debt, Mexico's bank creditors were upset about what they perceived to be an inappropriate use of a cheap facility in periods of pressure. This peculiar attitude of creditors (unhappiness to provide the insurance agreed upon on low terms in good times when hard times come) shows that the reality of private CCLs is partially at odds with how they are supposed to work in principle. However, there may be more efficient ways to design such private CCLs such as setting them with a spread relative to LIBOR rather than with a fixed interest rate and thus reducing the incentives of the borrower to capture an arbitrage gain in periods of pressure.

Thus, private CCLs have been so far a mixed bag. There are significant doubts about their true effectiveness as a crisis prevention tool.

\section{E. Vulnerability indicators}

Emphasis has been given to national balance sheet management at both the aggregate and sectoral (government, financial sectors and corporate sector) levels and the importance of managing liquidity and balance sheet risk. One aspect is the development of better indicators of vulnerability to risk. While early warning systems may be a component of this better monitoring of risks, this task is best left to the private sector and academic research.

There is some consensus that the IMF should not be in the business of providing to the markets estimates of the probability of currency and financial crises; it should instead provide the data and indicators (various measures of financial and debt ratios) that allow private investors to make their own assessment of such risks. In fact, having the IMF issue "yellow cards" and/or "red flags" in the form of specific quantitative assessments of the risk of a crisis would be dangerous. It would be subject to Type I and Type II errors (failing to predict a crisis that then occurs, or predicting one that does not materialize or, worse, triggering one that would not have otherwise occurred).

However, the development of better data and indicators of external vulnerability is an essential public good that the IMF should be able to provide to markets. One problem during the Asian crisis was confusion and lack of data even on basic measures of external debt. The recent agreement by the IMF members to extend the SDDS to external debt data (ideally disaggregated by currency, maturity, sectoral breakdown and residency of the holder of the claim) will go a long way in the direction of better information about exposure and will be a good basis for the development of more sophisticated indicators of vulnerability.

\section{Policy Regarding Reform of the IMF}


Because the large industrialized countries dominate the IMF, any discussion of their policies must consider their attitudes toward reform of the IMF. There is no shortage of suggestions to the effect that reform is needed. ${ }^{81}$

\section{A. The Nature of IMF Critiques}

Let us consider some of the arguments that have been made in the debate over reform of the IMF. ${ }^{82}$ We will not elaborate in detail on each one, or try to make a judgment among them; that is the task of other chapters in this conference volume. The arguments are of interest here as inputs to the US and G-7 positions on reform of the IMF.

Most evaluations begin with a sentence along the lines, "The IMF has made serious mistakes -- what better evidence than the severity of the 1997-99 crises in emerging markets?" But what comes next? Sometimes the critics go into sufficient detail to specify exactly what they think it is that the IMF has been doing wrong, and what sort of reforms are necessary. Here are some of the most oft-suggested reforms.

1. The IMF should encourage more exchange rate flexibility. Reluctance to abandon currency targets and to devalue in the face of balance of payments disequilibria led to the crises of 1994-1999.

2. The IMF should encourage more exchange rate stability, including firm institutional commitments such as currency boards or dollarization that will restore monetary credibility, rather than government manipulation of the exchange rate to gain competitive advantage at the expense of people's living standards.

3. The international community needs to make more official resources available for emergency programs, bailouts, debt forgiveness, and new loans. There was no good reason based in economic fundamentals for the East Asians to suffer the sudden reversal of capital inflows in 1997; under such circumstances it is the role of the IMF to plug the gap and restore confidence with large official packages of financial support. Thus, the IMF should become an international lender of last resort.

4. We need to address the moral hazard problem more seriously, because it is the ultimate source of the crises. Investors and borrowers alike are reckless when they know they will be bailed out by the IMF and G7. Thus, big bailout packages should be avoided and, whenever there is a run-off (no rollover) on private claims, semi-coercive forms of burden-sharing, such as concerted rollovers, standstills and capital controls, should be introduced to bail-in the private sector.

5. Countries need to adopt capital controls, to insulate themselves from the vagaries of fickle international investors.

6. Countries need financial openness and capital account liberalization, so they can take advantage of international capital markets, e.g., to finance investment more cheaply than

\footnotetext{
${ }^{81}$ Reviews include Krueger (1997). We do not have space here to consider in detail the World Bank and other MDBs.

${ }^{82}$ Many of the critiques, and a few defenses, are collected in McQuillan and Montgomery (1999).
} 
if they had to do it out of domestic savings, and to provide some discipline on domestic policies.

7. Country programs need easier monetary and fiscal targets; recent IMF programs have had too much macroeconomic conditionality, inflicting needless recessions.

8. Country programs need tighter macroeconomic discipline, since monetary and fiscal profligacy is the source of most balance of payments problems, and private investors can't be persuaded to keep their money invested in the countries without sound macro policies that restore investors' confidence during a crisis.

9. The IMF needs to customize conditionality to individual country circumstances. East Asia did not have the macro problems so familiar from Latin America 10. The IMF needs to require standardized and strict rules-based pre-certification in order for a country to qualify for IMF assistance.

11. The IMF, along with the World Bank, should pay more attention to the needs of poor countries, rather than those that are successfully developing and able to attract private capital, and should place more emphasis on poverty reduction in each country program 12. The IMF should remove any subsidy component in loans, and charge higher interest rates, close to private market rates. In any case, it should leave poverty reduction to the World Bank.

One could continue. But the point is clear. Some want more exchange rate flexibility, some want less. Some want more macroeconomic austerity and conditionality, some want less. Some want more bailouts, some less. Some want more capital controls, some less. Each odd-numbered point above contradicts each corresponding even-numbered point. But one can't have both more and less exchange flexibility, both larger and smaller bailouts, more open and more closed financial markets, both looser and tighter macro policies, both more and less customization of conditionality.

The principle is thus that "For every critique of the IMF there exists an equally forceful critique that is the diametric opposite." This of course does not refute that some number of these attacks could be justified. It does not let the IMF off the hook. Each argument should be considered on its merits. The point, however, is that most of the public debate is conducted at a level of sufficient generality that critics can give the impression of sharing a common viewpoint when they actually have contradictory points in mind. This can give politicians the very misleading illusion that reforms are straightforward to determine and easy to implement.

Critics on the right can give politicians the impression that the desirable reform is a simple matter of reining in the excessive interventionism of the G-7 and IMF. They conclude that all unbiased analysts agree that it is sufficient to let the private markets work on its own, to refrain from bailouts. The danger is that when such politicians get into office, they will soon discover a need to rescue important and sensitive countries, as their predecessors have done, after having made a point of saying explicitly they would not. 
Critics on the left make a strong case when they argue that the United States and other rich countries are currently devoting a very small level of resources to attempts to help poor countries. ${ }^{83}$ But the political obstacle to greater US support for multilateral institutions is the perception that most such funds have in the past not been well-spent. This perception has some basis in reality: some international agencies have been inefficient in the past. But the IMF has been one of the more efficient and cost-effective multilateral institutions. ${ }^{84}$ The danger is that the critics will succeed in tearing down the IMF, and then be disappointed when no new improved institution is substituted in its place.

\section{B. The Meltzer Commission Report}

While proposals for the reform, and even abolition, of the IMF abound, ${ }^{85}$ some have had a particularly political high profile. Specifically, the recommendations of the Meltzer Commission -- formally the International Financial Institution Advisory Commission created by the U.S. Congress in 1999 to provide suggestions for reform of the IMF and MDBs -- have received the most attention. Some of the recommendations of the Commission subsume, in one form or another, other proposals for IMF reform. Thus, consideration of the Commission recommendations provides an opportunity to analyze a number of other suggestions for the reform of the international financial institutions and the international architecture. (The role of ex-ante and ex-post conditionality, need for an international lender of last resort, use of collateral in IMF loans, market discipline, opening up of emerging economies to foreign financial institutions.) follows: ${ }^{86}$

The main recommendations of the Commission, presented in its report, were as

- The IMF should become a quasi international lender of last resort which provides large-scale, essentially unconditional support only to pre-qualifying countries that are sound in their financial system and fiscal affairs (ex-ante conditionality) but that suffer from international contagion nonetheless.

- The IMF should avoid ex-post conditionality and lending to countries in crisis that lack sound economies or policies and thus do not pre-qualify. It should provide only "counsel" and "advice" but no loans/support to such economies. This would effectively terminate existing lending programs, such as Stand-By Arrangements, of the IMF (and MDBs) in a wide range of emerging market economies.

\footnotetext{
${ }^{83}$ For reasons of space, we do not cover in this paper important questions regarding how to deal with poverty, what developmental policy should be and the status HIPC initiative to reduce the debt burden of the most poor developing countries.

${ }^{84}$ One would think it would be easier to explain to the public the merits of an organization that has nothing to do with foreign aid, but rather lends money in time of crisis, in return for countries' commitments to needed reforms, and is almost always repaid.

${ }^{85}$ See for example De Gregorio et al. (1999), Feldstein (1999b), Schultz, Simon, and Wriston (1998), and Calomiris (1998b).

${ }^{86}$ International Financial Institution Advisory Commission (2000). The Commission also made recommendations about Multilateral Development Banks (MDBs) reform such as taking the World Bank out of the development finance business and rely mostly on grants for World Bank support. We will not discuss here, given space limits, reform of the World Bank and other MDBs. We briefly touch upon these issues, especially the division of labor between IMF and World Bank, in section V.C below.
} 
- IMF loans to pre-qualifiers should be short-term (a term of four to eight months was mentioned), set rising penalty interest rates to encourage early repayment, and rely on security by means of a clear priority claim on the borrower's assets.

- Conditions for pre-qualification by IMF borrowers include: a) a sound banking system, including the opening of emerging markets financial systems to foreign banks; b) regular and timely publication of the maturity structure of a country's outstanding sovereign and guaranteed debt and off-balance sheet liabilities; c) adequate capitalization of commercial banks either by a significant equity position, in accord with international standards, or by subordinated debt held by non-governmental and unaffiliated entities; d) establishment by the IMF of a proper fiscal requirement to assure that IMF resources would not be used to sustain irresponsible budget policies.

To understand the main differences between the current structure of the IMF and that proposed by the Commission, one may think as the current IMF structure as based on four pillars, each requiring some degree of ex-ante or ex-post conditionality. The Commission instead effectively recommends an IMF with only one pillar that relies strictly on ex-ante conditionality. ${ }^{87}$ Let us consider briefly each of the four pillars.

First is a new CCL facility that is similar in some aspects to the one proposed by the Commission in that it relies on pre-qualification criteria (sound financial and fiscal and data transparency) and stresses ex-ante conditionality (pre-qualifiers would have access with little ex-post conditionality to relatively large IMF resources in case of contagion).

Second are regular conditionality-based loans (Stand-By-Arrangements) for countries that are small and non-systemic and have serious macro and financial problems and which therefore do not pre-qualify for large support. The idea of this pillar is that program conditionality provides the sticks to ensure reform while access to normal quota IMF resources provides financial support for policy adjustment by the country in difficulty. The majority of IMF programs -- currently and historically -- have been of this type, for countries who do make mistakes and do have crises but who would not prequalify under the stringent conditions of the first pillar, given macro and financial or structural shortcomings.

Third, the current system allows exceptional financing (i.e. financing in excess of normal quotas) to countries that would not pre-qualify for a CCL because of their policy imperfections but that are deemed to be systemically important and to require large amounts of support to adjust to severe crises, thereby preventing contagious effects on other emerging markets. These exceptional funding arrangements are the recently created SRF (Supplementary Reserve Facility) or other arrangements that provide loans in significant excess of normal quotas. The SRF was used in recent large support packages, for the first time in Korea in 1997 and then in Brazil, Argentina and Turkey. The Commission's view is that this third pillar should be phased out over time. But the Commission added an escape clause that would allow - in a transition period to this new

\footnotetext{
${ }^{87}$ The Commission would also accept the exceptional and transitory use (before the switch to the new long run regime) of a pillar of large financing for systemically important countries who are in crisis and do not pre-qualify for the large unconditional financing.
} 
long-run regime - for IMF large lending in exceptional cases in which significant contagion may occur.

Fourth, the last pillar of the current IMF system is the existence of subsidized lending facilities to very poor countries (ESAF and now PRGF) and multi-year lending at slow repayment rates to countries with serious structural problems or in transition to a market economy (the EFF or Extended Fund Facility). The Commission argued instead that the IMF should cease lending to countries for long-term development assistance (eliminate ESAF/PRGF while writing off all debt to HIPC countries) and for long-term structural transformation (as in the post-Communist transition economies, i.e., elimination of the EFF). Such functions should instead be moved to the World Bank and other MBDs.

The Commission's report argues that IMF packages, especially the large loans to countries having serious problems, exacerbate both creditor and debtor moral hazard; that ex-post conditionality is not effective and may even be harmful; and that a sensible longrun regime is one in which crises are prevented in the first place. It urges that a system of inducements (IMF support to sound economies) and sticks (no IMF support to unsound economies) will provide the right strong incentives for countries to implement reforms that will prevent crises from occurring in the first place. In addition, the Commission recommends that lending to poor countries and to countries that have structural problems or are in transition should not be the business of the IMF, which should concentrate on avoiding panics, runs and crises in sound economies that are subject to contagion. The World Bank and MDBs should instead deal with the structural and macro problems of these poor and transition economies.

The publication of the Commission report led to a public debate on its recommendations. Critics included minority members of the Commission, the U.S. Treasury Department and others. ${ }^{88}$ We will here summarize some of these critiques and relate them to the arguments made by the Commission.

Consider first the CCL. With the recent changes made to this facility, it is similar in some ways to that suggested by the Commission: countries would pre-qualify based on macro and structural criteria and exceptional financing would be quickly available for them. While this facility may play a role in the new international financial system, critics (for example, Treasury ,2000) believe that one should not overestimate its importance or place it at the center of a reformed IMF. For one thing, no country has applied (or qualified) for this facility yet, even after the reform of the facility. (Members of the Commission would argue that this is because the countries believe that if necessary they will be bailed out on more attractive terms.) Second, while it is possible that very sound economies may be subject to contagion from time to time, the likelihood of this happening may be limited. The history of banking crises suggests that sound banks rarely experience runs while bank runs are almost always triggered by poor financial conditions and policies of particular banks: poor lending, little capitalization, high and growing NPLs, et cetera. For the same reason, the possibility that contagion would lead to a run on a very sound country is relatively small: Even if a country would qualify for the CCL (or the similar facility proposed by the Commission), chances are that this facility would rarely be needed and used. If the above argument is correct, a CCL type of facility could not be the central element of a system of crisis resolution: Its importance would, in

${ }^{88}$ See Bergsten (2000), Levinson (2000) and Treasury (2000). 
practice, be limited to preventing occasional extreme episodes of contagion to otherwise sound countries.

Is there a role for the third pillar of the current system, exceptional financing for crisis countries who do not pre-qualify for the CCL? Critics (again, Treasury, 2000) argue that the Commission recommendations - if narrowly interpreted - would have disallowed financial support to most of the large and systemic economies enveloped in the financial crises of the 1990s (Mexico, Thailand, Indonesia, Korea, Brazil, Russia, Argentina, and Turkey). They probably would not have pre-qualified for IMF support given macro weaknesses (poor fiscal positions in Mexico, Brazil, Russia, Argentina, and Turkey) or structural policy weaknesses (weak financial sectors in Mexico, Thailand, Indonesia, Korea, Russia, Turkey). The third pillar of the current system, the SRF or other facilities allowing exceptional financing, was used in all these cases. The Commission would allow an escape clause in limited, transitory and exceptional circumstances where systemic problems are at stake and exceptional financing would be allowed. But a generous interpretation of this caveat would still imply that most of these large scale packages would have not occurred in a new regime where the IMF had been reformed along the lines of the Commission recommendations.

To understand the logic of the Commission's views, one should note that the Commission sees its suggested reforms as leading, over time, to a world where countries "get their act together," in the knowledge that large scale support would not be available unless the economy is sound. Thus, the Commission is aiming at creating a long-run regime where large-scale packages would not be made available to countries with unsound financial and fiscal policies. Also, according to the Commission, the recommendations would be phased in a period of five years, thus allowing countries the time to adjust their policies to this new regime of "no bailouts/support unless sound." Still, in the new long run regime, countries that are systemically important, but fail to adhere fully to the sound economy criteria for unconditional support, would not receive financial support.

The Commission supporters rebut that, in the new long run regime of a reformed IMF, countries would know that failure to satisfy the criteria for CCL-type support would lead to no support at all and this would provide a large incentive to clean up the economy and the financial system and thus prevent the kind of crises that afflicted these economies. But supporters of the current system, where exceptional SRF-style support for countries who do not otherwise pre-qualify for a CCL facility is maintained even in the long run, make various arguments: These crises may have systemic effects and thus the international community has to deal with them even if they were partly caused by poor policies. Although poor policies and weak financial systems may trigger a crisis, the case of Asia suggests that an element of panic and self-fulfilling runs prevails even in cases where fundamentals were not fully sound. Thus allowing large support to systemically important economies in exchange for a serious program of reform constrained by tight conditionality may be beneficial to the country and its creditors, and help maintain the stability of the international financial system. Indeed, in cases such as Mexico, Korea, Thailand, Brazil, Argentina, this exceptional support to countries that would have not pre-qualified for a CCL allowed macro and structural reform that benefited all relevant parties. 
The terms of the Commission recommendation for large-scale unconditional support to pre-qualifiers were inspired by - and founded on - the Bagehot principles for lender of last resort support. Nevertheless, they have also been debated and criticized by some commentators.

First, the implied scale of the support seems to be extremely large given the resources available to the IMF: the Commission suggested that such support might be as large as one year of a country's government revenues. Based on current data, Treasury (2000) argued that this would have implied lending to Brazil equal to $\$ 139$ billion . This is far in excess, not only of the country's quota in the IMF ( $\$ 4.5$ billion), but even of the size of the recent IMF program ( $\$ 14.5$ billion). In this view, such large packages would be well beyond the financing capacity of the IMF and would increase the moral hazard involved.

The second controversy regards the Commission's support for securing IFI loans by means of a clear priority claim on the borrower's assets. There are two substantial issues with this proposal.

In practice, IFIs already have quasi-preferred creditor status. Therefore, the extra gain may be small. If it is contemplated to use resources of the government as outright collateral for IFI lending, this may worsen the creditworthiness of the country in the eyes of the private sector. The historical practice of LOLR has been very different from the Bagehot principles that the Commission cites. Recent studies show that little real hard collateral has historically been used in LOLR lending. ${ }^{89}$

Third, regarding the idea of lending at penalty rates, note first that, as suggested by Giannini (2000), the Bagehotian principle calling for "lending at a penalty rate" and lending to "solvent but temporarily illiquid banks" has not been usually applied in historical cases of banking crises. Moreover, based on data from recent historical crises showing large and protracted spikes in sovereign spreads after a crisis, Treasury (2000) argued that lending at penalty rates would "entail in most cases interest rates so high that these loans would worsen the underlying financial position of the borrowing country." Thus, although penalty rates may make some sense and indeed, the SRF comes with penalty rates that are three percentage points above short term riskless market rates, systematic use of market rates on a country's debt would imply very high, and possibly unsustainable, borrowing rates. Also, given the seniority of IMF lending (which would be even stronger one if collateral is used), it does not make sense to use market rates that reflect default probabilities on less senior debt.

Fourth, the short-term maturity of the loans recommended by the Commission would have forced repayment prematurely relative to what was needed by these economies in crisis. (The Report mentioned four months, with only one further four-month extension. ${ }^{90}$ ) Even in successful large-scale IMF programs (Mexico, Korea, Thailand, Brazil), actual repayment lasted more than eight months. In this regard, note that even the

\footnotetext{
${ }^{89}$ Giannini (2000). Charles Calomiris tells us that the Commission support for this type of security is not support for collateral. Members of the Commission do not necessarily agree with the language we use to characterize their positions, in general.

${ }^{90}$ In Congressional testimony, however, one of the Commission members - Calomiris - suggested a more flexible interpretation of the maximum maturity of these loans.
} 
short-term SRF facility allows at least two years for repayment. Given the spikes in sovereign spreads occurring after crises and/or the effective cutoff of a country from access to international capital markets, excessively short repayment periods may end up being destabilizing.

The Commission would also eliminate altogether the second pillar of the current system. It would eliminate all lending to countries that experience a crisis because of their own policy shortcomings and that thus do not pre-qualify for support. They will have to adjust on their own without any IMF conditional support. These cases, regular SBAs to countries in macro and financial difficulties, represent the bulk of the program activities of the IMF. Thus, the Commission would drastically reduce the number of countries and cases where access to IMF lending is allowed. The IMF would provide only "counsel," not funding, to countries with complex and deep-seated problems. This recommendation is based on several arguments. First, the argument against funding with only ex post conditionality is the moral hazard argument. Countries believe that the IMF will rescue them if a crisis occurs. Hence they have less of an incentive to strengthen their financial systems until it is demanded by the Fund. If strengthening their financial system were instead made a pre-condition for receiving IMF credit, the argument goes, weaker countries would rush to adopt reforms that would secure their access to IMF resources. Ex ante conditionality is therefore believed by some to be more useful in limiting the incidence of crises or limiting the scope and duration of crises that do occur. Second, the Commission argues that ex-post IMF conditionality is ineffective in practice based on historical experience.

Critics (Treasury, 2000) of the proposal to eliminate standard ex-post conditionality lending programs make several arguments. First, they argue that IMF conditionality works both in theory and empirically. Conditionality works in theory because the IMF would not have much of an impact if it could provide only "counsel" to countries with complex and deep-seated problems. The same is true if it lent to countries without any desire or commitment to change,. Leverage comes from money, because the carrot of financial support is an incentive for policy adjustment and reform. These countries often need the catalytic financial support of the IMF, which in addition to conditionality and commitment to policy stabilization and reform, is crucial to restoring investors' confidence. In recent financial crisis episodes, IMF involvement and ex-post conditionality made the key difference, providing incentives for policy adjustment that was eventually successful in restoring economic growth.

Critics also argue that, empirically, IMF conditionality is more effective than argued by the Commission. Indeed, there is a broad empirical literature on the effectiveness of conditional IMF lending. Most studies have instead relied on large cross country samples that allow for the application of standard statistical techniques to test for program effectiveness, avoiding the difficulties associated with trying to generalize from the finding of a few case studies. The overall conclusion of such studies is that IMF programs and IMF conditionality have on balance a positive impact on key measures of economic performance. Such assessments show that IMF programs result in improvements in the current account balance and the overall balance of payments. This result is robust across a range of different methodologies. Haque and Khan (1999) provide a recent survey. ${ }^{91}$

${ }^{91}$ Kenen (2001, p. 53) criticizes the Commission report a selective quoting of Haque and Khan. 
The impact of IMF programs on growth and inflation is less clear. The first round of studies failed to find any improvement in these variables. More recent studies suggest that IMF programs result in lower inflation, but do not consistently establish that this result is statistically significant. ${ }^{92}$ The impact of IMF programs on growth is more ambiguous. Results on short-run growth are mixed; some recent studies found that implementation of IMF programs led to an immediate improvement in growth (DicksMireaux, Mecagni and Schadler, 1997) while other studies (Bordo and Schwartz, 2000) found a negative short-run effect. ${ }^{93}$ Studies that look at a longer time horizon, however, tend to show a revival of growth (Conway, 1994). This is to be expected: countries entering into IMF programs will often implement policy adjustments that have the immediate impact of reducing demand, but could ultimately create the basis for sustained growth. The structural reforms embedded in IMF programs inherently take time to improve economic performance. Finally, the crisis that led to the IMF program, not the IMF program itself, is often responsible for an immediate fall in growth.

Finally, there is a debate on the necessity of the final pillar of the current system, IMF support of macro adjustment and reform in very poor countries and transition economies. One view, espoused by the Commission is that any support to very poor countries should be transferred to the World Bank or MDBs, as the problems of these countries are too structural and complex. The view supported by the G7 and the IMF, instead, is that a proper division of labor between IFIs implies that the many macroeconomic problems of very poor and highly indebted countries should still be dealt with by the IMF in the context of a coordinated program of adjustment, reform and growth with the World Bank.

This division of labor and coordination is at the center of the recently designed Poverty Reduction and Growth Facility (PRGF). In the PRGF, IMF concessional lending for macro adjustment was broadened to include an explicit focus on poverty reduction in the context of a growth oriented strategy. The alternative of taking out of the IMF all the macroeconomic components of programs for poor countries has, in the view of critics, several shortcomings. First, these countries would effectively be non-members of the IMF, and as such would feel excluded from the international financial system. Who would be "kicked out" of the IMF, or who readmitted, would be a politically charged issue. Second, it is not obvious that the World Bank has the appropriate expertise in the macroeconomic area and effectiveness to enforce macro conditionality credibly in its programs. ${ }^{94}$ Other objections to the proposal include that the IMF, in phasing out its longer term facilities such as the EFF, would not be able to deal with the problems of transition economies.

\footnotetext{
${ }^{92}$ Conway (1994) found that inflation fell following an IMF program, and the result was statistically significant. Bagci and Perrudin (1997) also found a statistically significant reduction in inflation. DicksMireaux, Mecagni and Schadler (1997) found that programs do reduce inflation, but the result was not statistically significant.

93 Bordo and Schwartz (2000) compare countries receiving IMF assistance during crises in the period 1973-98 with countries in the same region not receiving assistance and find that the real performance (for example, GDP growth) of the former group was possibly worse than the latter.

${ }^{94}$ Some even argue that existing structural conditionality in World Bank programs is too soft and thus that IMF macro requirements and monitoring effectively become a useful cross-conditionality for World Bank programs and loans.
} 
In general, the issue of whether the IMF should make loans to very poor countries or provide long term facilities to countries with structural problems remains controversial. One can make arguments both ways.

A set of reforms of the IMF was agreed by the member countries at the time of the IMF meetings in Prague in September 2000. The reforms did reflect parts of the Meltzer Commission recommendations that were consistent with the views of the US and the other G7 countries. Indeed, the IMF reform proposals advanced by the US Treasury, while developed before the Commission presented its report, were partly aimed at deflecting criticism of the IMF in Congressional circles and pre-empting possible recommendations of the Commission. The US Treasury reply to the Commission report found a series of common reform goals that were shared by the Commission and the US administration. These included: agreement that the IMF should continue to have an important role in crisis prevention and a strong capacity to respond to financial crises; a radical change in the transparency of the operations of international financial institutions and of member countries; the development of new mechanisms for strengthening incentives for countries to reduce their vulnerabilities to crises; a focus within the IMF on the importance of sound financial systems, better debt and liability management policies and appropriate exchange rate regimes; and the need for a clear division of labor between the multilateral development banks and the IMF.

Despite these broad common objectives, however, the US administration remained "in fundamental disagreement with the Report's core recommendations for further reform" (Treasury, 2000). Thus, although the reforms agreed upon by the G7 were consistent with the spirit of the Commission goals, their detailed substance was substantially at odds with the more radical recommendations of the Commission. The reforms agreed by the G7 and the IMFC at the time of the Prague meetings are discussed in more detail below in section V.D.

\section{Mission Creep}

Perhaps the most widely held criticism of the IMF is that it has exhibited "mission creep," a term borrowed from the history of military interventions that eventually expand beyond their originally stated aim. There is some truth to this critique. ${ }^{95}$ The Fund has undergone significant role-changes, roughly once a decade.

The IMF's original mandate, under the Articles of Agreement negotiated at Bretton Woods, NH, in 1944, was to help countries with balance of payments difficulties, so as maintain a stable system of pegged exchange rates. A majority of members were industrialized countries. The goal of restoring convertibility among most industrialized countries had been achieved by the end of the 1950s. When the Bretton Woods system of fixed exchange rates broke up in the early 1970s, some charged that the IMF had lost its mission but in good bureaucratic tradition, refused to go out of business; instead it was filling the gap by turning its attentions to the developing countries, most of which had become independent over the preceding 15 years. ${ }^{96}$ This seemed an unfair criticism. The newly independent countries had as much right to belong to the Fund as anyone, and most of them maintained some species of exchange rate peg long after the major

\footnotetext{
${ }^{95}$ See Feldstein (1999) for a critique along these lines.

${ }^{96}$ Niehans (1976).
} 
industrialized countries had given them up. (There were plenty of problems to keep policy-makers busy in the 1970s, with the need after the oil crises to recycle surpluses in oil importing countries to deficit oil-importers.) Thus even a narrow interpretation of the Fund's role includes balance of payments problems in developing countries.

The role expanded in the international debt crisis of the 1980s. From its inception in 1982, Managing Director Jacques de Larosiere was active in the strategy to manage the crisis. It was a case-by-case approach (much as in the more recent episode), consisting of country programs that each featured three elements: policy adjustments by the country in question, loans from the IMF and industrialized-country governments, and agreement by private bankers to roll over loans and/or provide new money.

The next big change in the Fund's role occurred with the unraveling of the Soviet Bloc. The formerly-Communist countries -- now-transition economies -- joined (or, in a few cases, re-joined) the IMF. Clearly the problems in their transition extended far behind the standard IMF issues of macroeconomic policy, exchange rates and the balance of payments. But here the IMF faced the first of its big cases of "damned if you do, damned if you don't." It is universally agreed that a necessary condition for economic success in the transition economies is the establishment of property rights, the rule of law, and other well-functioning institutions. A common critique is that the G-7 and the IMF did not appreciate the importance of these factors, and the extent and importance of corruption in Russia in particular, and failed to do anything about them. At the same time, an equally common critique is that the IMF engaged in mission creep in the transition economies, by taking on tasks of structural reform that are more properly left to the World Bank. One could argue that a clearer division of labor and coordination between IMF and World Bank would have solved these opposite claims; but such an ideal outcome was certainly not easy to achieve.

The most recent evolution came with the emerging market crises of 1997-98. The IMF did not simply apply the same approach to East Asia that it had applied in the past to Latin America or other problem debtors (even if some of the macro components of these plans - tight fiscal and tight money - were initially similar). The new country programs emphasized structural reform more than macroeconomic austerity. This was appropriate, in that these countries have historically followed good monetary and fiscal policies. Restructuring of the banking system and strengthening of prudential supervision are prescriptions that are closely related to the roots of the crisis, and thus are appropriate subjects for IMF attention and conditionality, even if it means having to hire new personnel with expertise in this area. Issues of corporate governance or trade liberalization are also relevant, though they could be viewed as a bit more afield. At the extreme, issues of the environment, labor rights and human rights, while extremely important in the wider scheme of things, are clearly not relevant for the IMF's mandate. ${ }^{97}$

To include issues of banking supervision and corruption in the IMF purview certainly represents a relocation of the boundary line that separates the legitimate territory of multilateral governance from the inviolable territory of national sovereignty. How can this be justified? For years, the word "corruption," like the words "military spending" were virtually taboo at the IMF, because the governments of the member countries, who

\footnotetext{
${ }^{97}$ Thus, recent U.S. Congressional mandates that force the administration to push issues of trade liberalization, labor and union rights and environmental issues on the IMF agenda and condition U.S. votes on IMF programs on IMF consideration of such issues are seriously misguided.
} 
own and run the Fund, did not want them discussed. The inability to look at issues of military spending and corruption undermined the effectiveness of IMF programs, increasing the burden of austerity on the local population and decreasing the financial effectiveness of the programs. Perhaps the strongest argument for including such structural conditionality in IMF programs is that it is impossible for the international community to justify sending additional resources to a crisis country if everyone believes that the money will end up in the bank accounts of government cronies. As national economies become more highly integrated, it is not surprising if an accounting of costs and benefits results in some moving of the boundary, pushing back national sovereignty, in some well-chosen areas. Where the integration is financial, attempts by the international financial community to address any resulting crises may end up including structural conditions that, while though go beyond macroeconomics, are nonetheless relevant to the origin of the crises and to their effective solution.

Macroeconomic conditionality alone could not solve the Indonesia crisis of 199798 , because neither an overvalued currency nor excessive budget deficits were the original problem. Even best efforts to address problems of the banking sector would probably not have been able to solve the crisis. The ultimate origins of the Indonesian financial crisis were deeply rooted in corruption, the uncertainties of presidential succession, and the lack of commitment to policy adjustment and reform and the vulnerability of the Chinese minority. Many criticized the IMF program for a list of conditions that was so detailed as to include a dismantling of the clove monopoly; they miss the point that precisely such steps were deemed to be necessary to signal to investors that the economic interests of the President's family would no longer be allowed so fundamentally to distort the national economy. Many criticize the Fund and the G-7 for failing to realize that the President would never deliver on such promises; they miss the point that his failure to try to deliver is what led to his removal, in favor (eventually) of someone who might. Many criticize the Fund, the United States, and the entire international financial community for having supported Suharto all those years. They miss the point that it is neither feasible nor proper for the international community to remove local rulers, leaving aside extreme cases of egregious military threats; but that rulers may be forced by domestic constituencies to leave office as the result of a financial crisis that is in turn the consequence of their bad policies.

The Fund is arguably intruding on the traditional territory of the World Bank in three ways. The first, as just discussed, is the expansion beyond macroeconomic conditionality to include structural conditionality. The second is the increased emphasis on poverty reduction, embodied in the renaming of what is now the Poverty Reduction and Growth Facility. The third is the drift toward programs with longer terms, or toward a pattern of programs that are repeatedly renewed.

It is on the topic of poverty that the IMF is most thoroughly damned by critics either way. Expert assessments, from across the political spectrum, recommend a clearer division of responsibility between the two agencies, including a decision to leave poverty-fighting to the World Bank. On the other hand, critics hit the target with as much punch as the charge that the IMF serves the interest of wealthy capitalists, in both creditor and debtor countries, and that it is the poor who suffer the most unpleasant consequences of adjustment programs. A division of labor may be sensible as a matter of good public policy. Political considerations are also relevant, and protestors concerned with the poor 
will not like to be told "that is the World Bank's job." But they don't react much better when they are told "we are working on it;" so the Fund may not have much to lose by giving the Bank exclusive rights to the topic of poverty.

Finally comes the question of the length of time that patients are hooked up to the IMF support system. Not long ago, most programs ended in a few years, and the borrower repaid the Fund. It is still true that defaults to the Fund are exceedingly rare. But programs that are designed to be long term became more common in the 1990s (the Extended Fund Facility - EFF - for countries with longer term macro and structural problem or in transition to a market economy and the Extended Structural Adjustment Facility - ESAF - for very poor and highly indebted countries), as did cases where programs are repeatedly extended or rolled over. There is an open debate over whether the Fund should engage only in very short term financing or be involved in longer term funding to support structural adjustment.

Some argue that the division of labor between the IMF and the World Bank may need to be restored toward its traditional balance. In this view, the Bank's proper role is more extensive attention to structural issues, with special attention to poverty reduction, carried out through long-term lending programs. The Fund's proper role would instead be addressing shorter-term issues, including particularly financial or currency crises. Thus, in additional to traditional macro issues, IMF surveillance would also cover the soundness of financial systems, whose weaknesses were at the root of many recent crises. Even here, a division of labor could be implemented: the specific financial system reforms necessary to the restoration of confidence, macro stability and growth may remain under the IMF realm; those regarding the medium restructuring of the banking, financial and corporate sector could be taken over by the World Bank. And, given the partial overlap of issues in the financial area, the two institutions could cooperate and coordinate their action in this area. But this is only one of the ways in which the division of labor between the two institutions could be arranged.

Of course, a large percentage of IMF members, and a larger still percentage of users of IMF programs, are and will continue to be developing countries. And as the World Bank continues to place greater emphasis on the important goals of povertyreduction and environmental protection in its longer-term development programs, it is important to coordinate closely with the Fund. The warning that monetary stability is a pre-condition both for increasing aggregate income and for equitable income distribution is as true as it ever was.

Recommendations that the Fund turn some responsibilities back over to the Bank is not necessarily the same as agreeing with the argument that it has been guilty of a selfserving expansion of authority. In the heat of a crisis, actors scramble to cover whatever positions need covering. Perhaps it is inevitable that a smaller, more nimble institution, as the Fund is, will be quicker to step into a gap that opens up in such areas as banking regulation or corporate governance. But even supporters of the IMF's broadened role in the past few years say that it is now appropriate for the actors to return to their assigned positions. 


\section{Recent G-7 Initiatives to Reform the IMF}

The drive to reform the IMF picked up speed in the fall of 1999 for a number of reasons. First, the IMF had been subject to a number of critiques in the wake of the Asian crisis and it was useful to reassess its role and functions. Second, the recovery of the Asian and world economy from its crisis mode allowed concentrating attention on how to improve the international financial system and its main constituent bodies. Third, in the United States the Congressional resistance to IMF refunding in 1998 showed the need to address some of the concerns expressed regarding the role of the IMF. Congressional action to set up the Meltzer Commission; Congressional legislative mandates on areas where the U.S. should press the IMF in program design (labor issues, trade questions, et cetera); and the need to receive Congressional support for initiatives such as HIPC funding were also factors. Fourth, the G-7 dialogue on architecture reform that started in 1998 suggested that the G-7 would look at the issue of the reform of the international financial institutions.

The United States again took a leadership role in this debate. U.S. Treasury Secretary Summers presented in a December 1999 speech (Summers, 1999) the U.S. view on how to reform the IMF. The ensuing dialogue among the G-7 led first to a consensus on the main outlines of IMF reform by the time of the Spring Annual meetings of the IMF/WB (April 2000), and then to a more detailed consensus and approval by the IMF Board of specific proposals by the time of the Fall Annual meetings (September 2000 in Prague).

The main elements of the U.S. proposals, which were largely adopted by the G-7, were as follows:

- Promotion of the flow of information to markets, i.e., shift of IMF surveillance to promoting the collection and dissemination of information for investors and markets. This took the following operational form: (1) IMF encouragement of more countries to adopt and comply with the Special Data Dissemination Standard, including its new provisions relating to the reporting of reserves and addition to the SDDS of greater reporting of external debt data; (2) encouragement of countries to implement international standards and codes for sound policies; and public release of these assessments (the ROSCs); and (3) a request that independent external audits of central banks and other relevant government entities be done and published.

- Emphasis on assessment of financial vulnerabilities, not just macroeconomic fundamentals. I.e., a greater focus on the strength of national balance sheets to reduce liquidity and balance sheet risk at the aggregate and sectoral level through greater use of indicators of external vulnerability and better collection of data on external debt (via the SDDS) and via the development of guidelines for optimal public debt management. The U.S. also supported highlighting more clearly the risks of unsustainable exchange rate regimes by supporting corner regimes. While the IMF has placed renewed emphasis on the importance of sustainable exchange rate regimes, the overall G-7 consensus on this is not as radical as the U.S. position. Other G-7 members agree that exchange rate regimes should be sustainable but do not fully endorse the U.S. support for corner regimes in most cases. $^{98}$

\footnotetext{
${ }^{98} \mathrm{We}$ did not discuss the very important issue of the appropriate exchange rate regime for emerging markets as it is discussed in another paper of this conference (Edwards (2000)). The views of one of the coauthors of this paper can be found in Frankel (2000).
} 
- A focus of the IMF's attention on its core competencies (macroeconomic and financial sector stability) and a focus of its finance on emergency situations. This meant a more limited financial involvement of the IMF with countries, lending selectively and on shorter maturities. It also meant an IMF on the front line of the international response to financial crises, but not as a source of low-cost financing for countries with ready access to private capital, or long-term welfare for IMF "addicts,", i.e., countries that cannot break the habit of bad policies and repeatedly depend on IMF financial support. In the U.S. view, this implied a reform of IMF facilities to streamline and eliminate some longer-term facilities (such as the Extended Fund Facility - or EFF - and other smaller, narrowly-designed funds and facilities) and would change the pricing of the remaining three main facilities (Contingent Credit Line (CCL), Stand-by Arrangements (SBA) and Supplemental Reserve Facility (SRF)) to charge higher interest rates and limit the duration of most loans for the SBA and SRF and reduce the charges on the CCL to give incentives for its use by sound economies. On one side was the strong U.S. support of easier conditions for CCL access (given its support of this facility and the lack of countries applying to it after its design in 1998) and skepticism of the longer term EFF. On the other side was the opposing European view that the EFF should be maintained (especially for transition economies and poorer countries) and the CCL not eased too much (out of concerns about moral hazard and excessive large financial packages). The eventual G-7 consensus ratified in September 2000 by the IMF Executive Board eased the conditions for the CCL but maintained a role for the EFF (and eliminated most of the smaller facilities) while limiting and concentrating its use for transition economies and countries graduating from the Poverty Reduction and Growth Facility (PRGF) program (the new successor to the ESAF program for poor and highly indebted countries). The relative pricing of the three main facilities was also changed to incentivate CCL use and discourage longer term use of SBAs and SRFs. Measure to reduce IMF "addiction" (repeated use of IMF support) and strengthen post-program monitoring were also agreed.

- Modernization of the IMF as an institution. This is to take place via greater transparency (publication of a large number of official documents) and openness (dialogue with civil society an non-governmental organizations - NGO- and with the private financial sector through the new Market Conditions Consultative Group), including regular publication of the IMF's operational budget. The U.S. also supported a governing structure that is more representative and a relative re-allocation of member quotas. But reform of IMF quotas has remained highly controversial and a consensus has so far eluded the G-7 and emerging market countries. An increase in the quotas of emerging markets is envisioned in most reform solutions (for example, those of the official Quota Formula Review Group or "Cooper Group" after the name of its Chair). But this would also imply a shrinkage of European countries' quotas (which currently compose one third of the executive director positions within the IMF Board), a solution strongly resisted by the European countries.

- A new focus on growth and poverty reduction in the poorest countries via efforts to translate debt relief for the Heavily Indebted Poor Countries (HIPC) into concrete reductions in poverty through the PRGF.

The above reforms of the IMF proposed by the G7 at the time of the G7 summit were endorsed by the IMFC at the time of the IMF meetings in Prague in September 2000 and operationalized during the fall of 2000, especially the reform of the IMF facilities. 
Regarding the latter, the CCL was enhanced by reducing the surcharge on the use of credit under the CCL and the commitment fee and by increasing the amount of funds available for borrowing at the time of activation. The use of the longer term EFF was restricted and the time period for repayment of EFF loans reduced. Similarly, the repayment period for Stand-By loans (purchases in the credit tranches) was also reduced to incentivate faster repayment of IMF loans. Conversely, the interest rate on exceptionally sized loans, such as those in the SRF, was increased based on an increasing scale. Finally, Post-Program Monitoring by the IMF of economic developments and policies after the end of a program was operationalized.

\section{Proposals for Alternative Institutions and Tools for Crisis Prevention/Resolution}

In this part we discuss a number of proposals for an international lender of last resort (VI.A) and alternative institutions and mechanisms/tools (VI.B) to deal with international financial crises, both in the crisis prevention and crisis resolution areas. ${ }^{99}$

\section{A. International Lender of Last Resort (ILOLR)}

There has been a wide debate on how liquidity crises are to be addressed: full bailout by an international lender of last resort (ILOLR) or bail-in (appropriate PSI)? In cases in which there is a pure liquidity crisis the case for an international lender of last resort might have a stronger basis. At the national level, the central bank can carry out the lender of last resort function when there is a liquidity run on domestic banks. There is no international equivalent of a lender of last resort, however. The IMF comes closest, but it does not have the capacity to provide unlimited funds to countries in crisis or to print/create international liquidity at will. Thus, several authors (for example Fischer (1999)) have suggested that an ILOLR function should be bestowed on the IMF or on some equivalent international institution (a global central bank as proposed by Garten, 1998).

Indeed, some argue that in pure liquidity cases, large "bailout" packages are justified and no PSI ("bail-in") of private investors is warranted. Thus, the debate on whether an ILOLR is necessary in liquidity cases has been strongly linked to the debate on whether PSI is necessary in liquidity cases. As the discussion below suggests, the issue is much more complex than the simple argument that a full bailout via an ILOLR is appropriate in pure liquidity cases.

\section{VI.A.1. Full bail-out (an ILOLR function) or full bail-in in liquidity cases? Some conceptual issues}

\footnotetext{
${ }^{99}$ Eichengreen (1999) and Rogoff (1999) each consider a broad range of plans, including a global lender of last resort facility, an international bankruptcy court, an international debt insurance corporation, and unilateral controls on capital flows.
} 
An official G-7 doctrine for pure liquidity cases has not been fully articulated and presented because of the complexity of such cases. Indeed, even the official PSI doctrine as elaborated by the G7 only partially addresses the question of what to do, if anything, in liquidity cases, especially if the country is large and has systemic effects. ${ }^{100}$

The issues in these liquidity cases are very difficult. First, it is not obvious whether there are "pure" liquidity cases. Formally, a crisis country may not be insolvent but rather illiquid in the sense that its debt servicing problems are caused by sudden illiquidity; however, even such a country may have weak fundamentals and serious policy shortcomings. Indeed, it is hard to believe that a country with fully sound fundamentals and policies would become illiquid and subject to self-fulfilling speculative runs and panic. For one thing, even in theory, if fundamentals are strong enough such multiple equilibria runs may be ruled out; i.e. weak fundamentals are necessary for an economy to be in the multiple equilibria region. Also, empirically all observed cases where something close to an illiquidity problem was the proximate cause of the crisis, were characterized by some fundamental or policy weaknesses. In cases like Mexico, Korea, Thailand and Brazil, which are conceptually closer to the illiquidity problem, some serious macroeconomic, structural or policy shortcomings certainly played a role in triggering the crisis. Thus, talking of pure liquidity cases and what, if any, PSI to implement in such cases is somewhat unrealistic.

But, for the sake of the conceptual argument, let us consider first "pure" liquidity cases. Some argue that a solution closer to very large official support packages (full bailout via an ILOLR) may be warranted in cases of pure illiquidity. It is also argued that this full bailout solution might be necessary if the country is not only illiquid but also large and of systemic importance. ${ }^{101}$

100 The PSI framework is meant to cover both liquidity cases and semi-insolvency or insolvency cases, but emphasizes the latter and de-emphasizes the former. The preamble of the G-7 operational guidelines suggests two approaches to liquidity cases - catalytic financing and voluntary arrangements that recognize the collective interest in staying in. The overall approach to liquidity case is case-by-case but constrained by the PSI framework, as for the other cases. But the G-7 has not addressed head-on the role that restructurings/ reprofilings should play in liquidity cases. For example, one should not lump the PSI approach to Korea with that to Brazil, as the commitment to stay in Korea was much firmer and led to formal extension of maturities via rescheduling. And the G-7 guidelines for restructuring do not explicitly apply to liquidity cases. Thus, there is still a lot of room for fleshing out the G-7 views on liquidity and systemic cases.

${ }^{101}$ A complex issue to be discussed below is what to do if the country is large and systemic but its crisis is not purely due to illiquidity; i.e. what to do if serious macro and policy shortcomings are at the root of the crisis. The current IMF/G7 doctrine for both systemic and non systemic cases suggests that, when catalytic IMF financing, policy adjustment and soft/voluntary forms of private sector involvement are expected to restore market access and investors' confidence, this route could be followed - but be substantially justified when exceptional financing is involved - not precluding the use of stronger forms of PSI if such catalytic approach does not succeed. The recent use of exceptional financing in the cases of Argentina and Turkey could be rationalized by arguing that may be cases where catalytic financing and policy adjustment are deemed to be likely to restore market access and investors' confidence. However, the use of stronger forms of PSI cannot be ruled out in case this catalytic approach were not to succeed. Moreover, the Turkish package includes a soft form of PSI a' la Brazil and in the spirit of voluntary approaches to PSI: the Turkish authorities met in mid December with their bank creditors and received commitments that such creditors will maintain their cross border exposure to the country. And the expectation that such exposure would be maintained was reaffirmed by the IMF even when the Turkish peg broke in February 2001. Thus, the large packages for Turkey and Argentina cannot not be interpreted as cases where PSI was neglected or ruled out altogether. However, in the Turkish case, the significant roll-off of cross border interbank lines 
While in such pure liquidity cases one could conceptually make the argument that a "full bailout" is the efficient policy, one could also argue that the alternative policy of a "full bail-in" (i.e. a combination of wide standstills, capital controls and other measures to lock in all investors that are rushing to the door) is as efficient and optimal. Indeed, if there is no uncertainty and no risk aversion, and there is a pure liquidity problem/run, both the full bailout and the full bail-in solution are equivalent solutions to the collective action problem faced by investors (the coordination failure) that is the cause of the liquidity driven run. So, paradoxically, the full bail-in solution is optimal even in the cases in which the full bailout solution appears warranted.

Paradoxically, in these pure liquidity cases, the bail-in solution may be superior to the bailout one as the ex-ante threat of a full bail-in solution is sufficient to sustain exante the good equilibrium of "no run" without having to resort to such a threat ex-post. In fact, if all agents know that, if and when a run occurs, the official sector or debtor will introduce standstills and/or capital controls to avoid the run, the incentive to run will disappear as everyone will know that no one will have the incentive and desire to rush to the door and no real losses will be incurred. In the domestic analogue, no one will want to stand first in the line at the bank if a bank holiday prevents the run from occurring. Thus, the threat of a full bail-in is sufficient to rule out the bad equilibrium and, ex-post, no run will occur and the threat will not be exercised, thus avoiding the need to implement the threat in the first place.

This conceptual superiority of the full bail-in solution is, however, extremely fragile in practice. In fact: a) if the case under consideration is not one of pure illiquidity but one in which some policy shortcoming are behind the illiquidity; b) if there is some uncertainty about the fundamentals and the policy response to the crisis; and c) if creditors are risk-averse; the dominance of a "full bail-in" solution will break down. When fundamentals are weak and uncertain and agents are risk-averse, they will react to the expectation or threat of a bail-in by rushing to the front of the line as the threat of a bail-in may actually be implemented and as such bail-in may imply real costs and financial losses to investors when the country is subject to shortcomings of policy and fundamentals rather than being purely illiquid.

So, what is to be done with liquidity cases, especially considering that some policy shortcomings imply that these are not going to be "pure" liquidity cases? A full bail-in, a full bailout, or something in between? One view is that, if one were to apply the logic of PSI, i.e. that some external financing gaps may occur, that official money will not be enough to fill such gaps and that a solution based only on official money (full bailout) is not appropriate because of moral hazard distortions, then the official sector would want to do a combination of things. Specifically, part of the solution would be policy adjustment by the debtor country if macro, structural and policy shortcomings caused the crisis. Part of the solution would be official money, the larger the package the closer one is to a pure liquidity case and the smaller when shortcomings are important. And part of the solution might be appropriate forms of PSI that are more or less "voluntary" depending on the circumstances and the nature of the problem being addressed and that will take the form of "partial" bail-in, i.e., include only a subset of instrument and creditors that may be running.

since the February 2001 devaluation makes doubtful the argument that soft and voluntary "commitments" to maintain exposure can be credible or effective. 
Indeed, in recent liquidity cases (Mexico, Korea, Brazil), the response has been a combination of policy adjustment, official money and PSI with the relative weights being different in different circumstances. Mexico was a case closer to that of full bailout of investors (cum domestic policy adjustment). Korea was closer to a semi-coercive rollover of interbank lines as the loss of foreign reserves had put the country close to the brink of default in the face of the attempt of foreign banks to reduce their exposures. Brazil was in between with a mild form of PSI (a monitoring of bank exposure followed by a commitment to maintain exposure at reduced levels) that combined with policy adjustment and significant official support was successful in avoiding a wider loss of confidence and prevented a disruptive loss of market access.

And the official sector response to these liquidity cases has been based on the view that a combination of adjustment, catalytic official money and appropriate PSI (partial rather than a full bail-in) can be successful in preventing a wider crisis, restoring confidence and market access, and returning the country to a path of recovery and growth.

Conceptually, however, the "middle" solution, as opposed to the "corner" solutions of full bail-out or full bail-in has been intellectually challenged as not being feasible. Observers (such as Paul Krugman) have argued that only corner solutions are feasible in these liquidity cases ${ }^{102}$ : either there is an "international lender of last resort" (ILOLR) with enough resources to engineer a full bail-out and avoid a disruptive run; or, at the other extreme, a full bail-in (that locks in all assets and domestic and foreign creditors trying to turn short term claims into foreign assets) is necessary. In fact, in this view a partial bail-in would not work because, as long as the economy is in the multiple equilibria region, locking in some creditors and assets, but not all, would lead all the others to run to avoid being locked in next. Conversely, a partial bail-out would not work either because, as long as the financing gap is not eliminated, the multiple equilibria problem is not solved and agents will rush to the exits and trigger a default by claiming all the limited foreign reserves including those provided by the partial official support. Thus, conceptually, it is argued that the "middle" solution may not be feasible.

Indeed, the Krugman hypothesis is supported by some theoretical work. Zettelmeyer (1999) formalize this hypothesis by showing that partial bail-outs are bound to fail in models where illiquidity may lead to self-fulfilling speculative attacks. Such partial bail-outs (or bail-ins) would not avoid the possibility of a bad equilibrium because, as long as the size of the support is not large enough to fill the financing gap, the possibility that agents will coordinate on the bad equilibrium cannot be ruled out. Worse, a partial bailout implies that the greater is the official support, the larger is the reserve loss if a run occurs. Indeed, if a partial package cannot avoid a run, the operating constraint on the size of the run is the amount of official reserves (including those provided by the bailout package); thus more support in this case means only a larger run on reserves.

This theoretical ineffectiveness of "middle solutions" (partial bail-outs and partial bail-ins) is in contrast to the official sector PSI doctrine that catalytic official money, domestic policy adjustment and partial and appropriate bail-in might indeed succeed and

102 Mervyn King (1999) is substantially in favor of "middle way" solutions but also suggests that corner type of solutions (such as broad standstills on debt payments) may at times be necessary to stem a crisis. The issue of standstill has been discussed in more detail in Section II above. 
avoid the bad equilibrium even when such a three-pronged solution does not formally fill all of the external gap. The middle view solution is predicated on the view that this combination of action will restore confidence and lead investors who are not bailed in, and who could thus run for the exit, to avoid running even if the remaining external financing gap is large enough that if they were to decide to run the bad equilibrium could not be avoided.

The gap between the theoretical analysis (which supports the "corner" solutions) and the actual policies and case studies (which support the view that "middle" solutions can be successful) can be bridged as follows. In multiple equilibria models, as long as the financing gap is not completely filled via full bail-in or full bail-out, the possibility of a self-fulfilling run cannot be ruled out completely: the economy may end up in the bad equilibrium if those who are not bailed in do decide to rush to the exits. Moreover, in the multiple equilibrium region, there is nothing (apart from "sunspots") that can nail down the probability that the economy will end up in the bad equilibrium as opposed to the good equilibrium. Since the bad equilibrium requires that enough agents decide to focalize on that equilibrium (i.e., decide to run), the question is how much fundamentals and policy actions can affect such decision. In existing models, this probability is indeterminate and the economy may be as likely to end up in one equilibrium as the other.

In reality, however, domestic policy choices, official support and the amount of bail-in do affect the probability, even if they do not do so in current analytical models. Indeed the argument for a "middle" solution is based on the view that domestic policy adjustment will reduce the probability of a run as the debtor government credibly commits to reduce the imbalances that created the risk of a run in the first place; that the amount of official support can also affect the probability of a run as more official money means that the size of the remaining gap is proportionally reduced; and that appropriate PSI may also reduce the probability of a run by leading some investors and asset classes to stay in (voluntary and/or concerted rollover) and leading the others who are not subject to bail-in not to run as the domestic adjustment, the official money and the bail-in of some other investors help to restore the confidence of the remaining ones. Thus, while a theoretical understanding for middle solutions (with different degrees of partial PSI) has not been developed, they do appear to work in practice as recent episodes (Mexico, Korea, Brazil) seem to suggest.

In practice, this has led the G7 and the IMF to conclude that liquidity and systemic cases should be dealt with on a case-by-case basis: no simple or rigid rules can be applied and all relevant factors may have to be considered to decide whether and how much PSI should be applied. Moreover, some argue that some degree of "constructive ambiguity" might have to be maintained in this regime to provide the appropriate response to specific cases and avoid expectations of systematic bailouts.

This view that middle solutions may work in practice does not go unchallenged. Some argue that recent episodes, such as Mexico, Korea and Brazil, are consistent with the view that only corner solutions can work. Indeed, the evidence from these three cases studies is ambiguous on whether "middle" solutions are feasible. All cases had some middle-solution component as official assistance was well below the size of assets that 
could have been run upon but a careful analysis suggests that these cases are also, in some dimensions, closer to the corners ${ }^{103}$.

Moreover, corner solutions have a number of practical shortcomings: a full bailin, as discussed above and as we discussed in more detail when we considered standstills (section II.C), may lead to a rush to the exits and contagion in a world of uncertainty and risk-averse investors. At the other extreme, a full bail-out solution also implies the effective existence of an international lender of last resort (ILOLR) that might be problematic for reasons that will be discussed next.

\section{VI.A.2. ILOLR, Too Big to Fail (TBTF) doctrine and appropriate PSI}

What can a full bailout solution achieve and does it require the existence of an international lender of last resort (ILOLR)? Since countries suffering of illiquidity, often do so because of some fundamental or policy weakness, if unlimited resources were available to a country with fundamental weaknesses, the funds lent by an ILOLR facility would be used by domestic and foreign investors to liquidate domestic assets and turn them into foreign ones, eventually exacerbating the crisis rooted in weak fundamentals. This is also the reason why, in a domestic context, it would be destabilizing to give extensive and unconditional lender of last resort support to banks that are in serious financial distress or bankrupt. Allocating more funds to such banks leads to moral hazard, i.e., "gambling for redemption," as the S\&L crisis and many other episodes suggest. This is also why the response of a central bank to a banking crisis caused by poor behavior of the banking system is to provide emergency support (to avoid panic) in exchange for very strict controls and restructuring of the financial institution under distress.

In an international context, there are three implications of the above observations.

First, if a country in severe distress because of fundamental weaknesses received unconditional ILOLR support, such support would bail-out investors and eventually fail to prevent a crisis as the country is in serious fundamental distress in the first place. Second, if support is aimed at providing incentives for reform and adjustment, then the support is likely to be of the conditionality form that comes with IMF packages. Third, if bailing-in private investors is motivated by the goal of reducing moral hazard, the amount of support would have to be lower than the amount of total domestic assets that could be potentially converted into foreign currency; i.e. official financing support that is only partial would contribute to reducing such moral hazard distortions.

What about the issue of big money packages? How large should IMF packages be and under which conditions should exceptional finance be provided? In the early decades of the life of the IMF, when international capital mobility was not widespread and restrictions to capital flows dominant, it historically was not allowed to provide large and exceptional support for crises generated by capital account problems. IMF was restricted to providing financing limited to current account problems. Capital account liberalization and the growing size of international capital flows led to the emergence of financial crises driven by capital account problems, the type of liquidity crises associated with the existence of large stocks of short-term foreign debt that may not be rolled over when confidence was lost. Hence, the trend to develop facilities such as the Supplemental Reserve Facility (SRF), the General Agreements to Borrow (GAB), the New Agreements

\footnotetext{
${ }^{103}$ See Roubini (2000) for a discussion.
} 
to Borrow (NAB) and the Contingent Credit Line (CCL) that would allow these capital account crises to be addressed.

Consider now the issue of big money packages. Assume a country experiencing a crisis because of weak fundamentals is large, suffers from a liquidity problem, is systemically important, is a potential source of contagion to other countries, and suffers a capital account crisis (due to creditors' unwillingness to roll over bank loans and other short term credit); large financial packages significantly in excess of quota may be able to stem default due to illiquidity and avoid further international contagion.

In this respect, such big packages for systemically important countries are the international equivalent of the too-big-to fail (TBTF) doctrine in the domestic lender of last resort context. Just as governments do not usually let big banks fail even if not all of their liabilities are covered by deposit insurance because of concerns of systemic effects and contagion to other sound banks, so the international community may act to prevent big countries from defaulting for the same reasons.

A domestic TBTF doctrine may increase the risk of moral hazard. However, in a domestic context there are a number of mechanisms that limit such a risk; also, there are differences between the domestic and international economy context that may exacerbate the moral hazard problem in the international context.

First, in a domestic economy both large and small banks are subject to ex-ante direct regulation and supervision, reserve requirements, capital adequacy standards, deposit insurance with risk adjusted premia. Thus, supervisors and regulators have broad powers to control the behavior of such banks before financial distress forces the authorities to bail them out.

Second, while the Federal Deposit Insurance Corporation Improvement Act (FDICIA) provides an out for systemically important institutions, such a doctrine was never formally embraced by the Fed and there are a number of hurdles to such TBTF rescues: the Fed Board has to take a major vote and there has to be concurrence by the Secretary of the Treasury. Moreover, some constructive ambiguity is used to prevent expectations that large institutions will be systematically rescued on a regular basis.

Third, once a TBTF institution is rescued, the authorities have a broad range of powers to dispose of it: it may be cleaned up, or recapitalized, or merged with other institution or even closed down and liquidated. Also, while an institution may be rescued to avoid systemic contagion, its managers and shareholders may be replaced. Thus, the moral hazard problems of rescuing the institution are reduced, even if there is still the issue of covering the depositors, including the un-insured depositors. In an international context, the idea of taking over countries, closing them down and merging them with others or replacing their shareholders is quite meaningless (in an era where, fortunately, debtor's prison and gunboat diplomacy are no longer options). Moreover, the kind of preventive regulation and supervision that is imposed on TBTF institutions in a domestic context is also severely limited in an international context. Sovereignty issues as well as the lack of leverage of the IMF over countries that are not yet in a crisis, and thus do not have an IMF program, limits the ability to provide such ex-ante supervision and regulation. Thus, while in a domestic context moral hazard deriving from expectations of TBTF support may be tempered with adequate supervision and regulation, the same cannot be easily done in an international context. 
In general, while TBTF arguments for big money packages for systemically important countries have some merit, the potential moral hazard distortions created by such programs have to be carefully addressed. In an ideal world, one would provide relatively large money packages mostly to sound economies without any substantial weaknesses (the type of economies that qualify for the IMF's CCL support). One would want to minimize the use of big money packages for the many cases where serious fundamental fragilities interacted with illiquidity to generate financial crises. If one had to design a long term regime from scratch, big money packages would not normally be part of the rules of the games, apart from very clear liquidity cases and where significant contagion is due to systemic effects. ${ }^{104}$ A credible commitment to avoid big money would force borrowers and creditors to be more cautious in their investment and borrowing decisions; and, if crises did occur because of a loss of confidence, adequate market mechanisms to avoid a generalized financial meltdown (orderly workouts, concerted market-based rollovers, insurance schemes based on private credit lines) would be found.

This purely market based solution with no big money bailouts may not be feasible or credible in the current regime and, even in an historically perspective, banking crises and international financial crises were messy and protracted when domestic and international financial lenders of last resort were missing. However, if investors, debtors and the official sector will continue to live in a world where the TBTF doctrine will be at times implemented for countries that are systemically too important and contagious, there is a need to design mechanisms that would minimize the moral hazard and the distortionary effects of such doctrine.

In a domestic banking context, the Federal Deposit Insurance Corp. Improvement Act (FDICIA) increased the likelihood that uninsured depositors and other creditors would suffer losses when their bank fails. The fix was incomplete, however, because regulators can provide - subject to a Board decision with which the Treasury must concur - full protection when they determine that a failing bank is too-big-to-fail (TBTF) - that is, its failure could significantly impair the rest of the industry and the overall economy. Some, for example the Minneapolis Fed, have argued that the TBTF exception is too broad; there is still much protection. Consequently, the Minneapolis Fed has proposed amending FDICIA so that the government cannot fully protect uninsured depositors and creditors at banks deemed TBTF. ${ }^{105}$ The proposed reform attacks the problem of 100 percent coverage by requiring uninsured depositors of TBTF banks to bear some losses when their bank is rescued. Such reforms, by increasing market discipline, may make bank runs and panics more likely.

Consider now how such proposals to limit TBTF-related moral hazard could be applied in an international context. The answer is that some form of private sector burden-sharing (PSI) would replicate the type of incentives suggested by the Minneapolis Fed to limit the perverse effects of an international TBTF. This means that, even (or especially) in cases of liquidity crises, investors would be expected to participate in burden sharing (commitment to rollovers, concerted semi-voluntary rollovers and even small haircuts depending on the circumstances) when a TBTF country is receiving a big

\footnotetext{
${ }^{104}$ This is the logic of having a facility like the IMF's SRF.

${ }^{105}$ This Fed proposal was first advanced in the Minneapolis Fed 1997 annual report; see http://www.mpls.frb.org/pubs/ar/ar1997.html.
} 
money package. The need to limit moral hazard would thus be a fundamental reason for including meaningful PSI for large countries that are receiving big money packages. Indeed, systematically rescuing such large international investors - cross border bank activities of international banks and highly risky investments of sophisticated international investors -- on the basis of the risk of a run on a systemically important illiquid country would exacerbate the moral hazard problem of large rescue packages. ${ }^{106}$

In conclusion, the appropriate form of PSI in liquidity and systemic cases is a complex issue. The G7 and IMF approach has been to deal with these on a case-by-case basis, considering all factors in the case in deciding whether and how much PSI would be applied. Some degree of constructive ambiguity has been maintained in official doctrine, justified as necessary to provide the appropriate response to specific cases and minimize the moral hazard problem of "too-big-to-fail" expectations. Ideally, some combination of significant - but not systematically exceptional - official finance, domestic adjustment and cooperative, semi-voluntary and least-coercive PSI of some categories of debt could restore confidence, prevent a wider crisis and provide a middle solution to a crisis. Such a "middle solution cum constructive ambiguity" may address the tradeoff between the need to avoid moral hazard deriving from systemic expectations of bail-out and the risk that self-fulfilling runs occur in cases closer to the illiquidity corner.

\section{B. Some specific proposals for new institutions or mechanisms/tools to prevent and resolve financial crises}

In the aftermath of any general crisis comes a variety of proposals for entirely new institutions or mechanism to prevent and resolve crises.

\section{VI.B. 1. The Asian Monetary Fund}

The idea of an Asian Monetary Fund (AMF) was first advanced by Japan as a way to contain the emerging Asian financial turmoil in late 1997. The idea was that such a fund could pool regional resources to be used by countries in the region to defend their currencies against speculative attacks. The issue of an AMF became contentious as the United States successfully rejected this idea. It argued that it would compete with and duplicate the IMF and that there was a danger that the conditionality attached to the lending of this fund would be soft, undermining IMF conditionality and weakening the discipline to follow appropriate macro and financial policies. As the Asian crisis worsened, some lingering resentment remained among the Japanese and other Asians who argued that such a Fund could have successfully stemmed or limited the Asian crisis and contagion throughout the region.

\footnotetext{
${ }^{106}$ Avoiding these ex-post bail-out of cross border interbank creditors is easier said than done. As the recent crisis in Turkey in December 2000 suggests, such uninsured creditors may panic when there are problems in the banking system and they are worried about serious losses. Thus, they are likely to run if expectations of a serious banking crisis emerges; thus, the monetary authorities might be forced, ex-post and at the cost of moral hazard distortions, to extend deposit insurance to these uninsured cross border liabilities to prevent a run. But this provision of ex-post insurance was provided under the proviso that international banks commit maintain their exposure level to the level existing at the time of the crisis (December 2000). This was the main PSI component of the IMF rescue package in Turkey. A similar quid quo pro was implemented in Korea in 1997; the banks accepted to rollover their exposure into medium term bonds in exchange for a government guarantee of such lines.
} 
Such a fund might not have been successful in its short-run goal of ending the crises, even leaving aside the longer-run moral hazard issues. For example, Thailand almost exhausted its foreign reserves in the spring and summer of 1997 in spite of attempts to control the outflow of capital. It is not obvious that another $\$ 10$ or $\$ 20$ billion of borrowed reserves would have made any difference. Most likely it would have been lost and the eventual currency adjustment merely delayed. History suggests that when parities are unsustainable, sterilized intervention is ineffective and may just feed the short positions taken by speculators. Unsterilized intervention is more effective but the same results on interest rates can be obtained through domestic open market operations. One might argue that it may be better to save precious reserves that are a dam against liquidity risk and rather use domestic interest rate policy (domestic open market operations) if a defense of the peg is deemed to be appropriate. But note that policies of semi-soft pegs before the crisis contributed to overvaluation, large current account deficits, lack of foreign exchange hedging and moral-hazard-related distortions to borrow in foreign currency. Thus, many believe that a currency adjustment was unavoidable in several crisis-affected economies in Asia and that neither unsterilized intervention nor interest rate defense could have prevented the eventual break of the currency pegs.

There are other motivations behind the Japanese push for an AFM, a push that has been later resurrected in the form of an initiative for closer monetary cooperation in the Asian region. For one thing, with the beginning of EMU and the emergence of the euro, the Japanese are concerned about the potential long-run marginalization of the yen as an international currency and the emergence of a world where the US dollar and the euro are the only two major international currencies. Thus, closer monetary cooperation is one way to stimulate the development of a yen region and the international role of Japan's currency. But whether or note the yen is the right regional currency for Asia is not clear as the patterns of trade and financial flows of the countries in the region show the Western Hemisphere (and Europe as well) and their currencies as major trade and financial partners. Furthermore, many Asians would prefer US leadership in the region to Japan's, out of lingering historical resentment against the latter.

Asian countries and Japan have always shared an aversion to purely floating exchange rates. The view of the United States Treasury after the Asian crisis, that middle regimes are unstable and that corner solutions may be better than intermediate middle regimes, has not been really accepted by Japan and other countries in the region that still see some form of managed rates as possible and desirable. Indeed, some countries in the region (Korea, Thailand) appear to have used systematic intervention in foreign exchange markets in 1999-2000 to prevent excessive appreciation or depreciation of their currency, a move in the direction of heavily managed exchange rates such as those prevalent before the Asian crisis. In that context, an AMF or other forms of monetary cooperation (such as the recent decision of some countries in the region to increase and extend their forex swap lines) can be seen as way to ensure that exchange rate stability is maintained in the Asian region. In the view of some, the European ERM/EMU appears as a model of how Asian monetary cooperation should evolve over time. ${ }^{107}$ But whether Asia is an optimal currency area is a complex issue that has to be analyzed separately. ${ }^{108}$

\footnotetext{
${ }^{107}$ At the January 2001 meeting of the European and Asian Finance Ministers (ASEM) a joint French and Japanese paper was presented supporting the idea of limiting the degree of exchange rate flexibility in the Asian region; the paper argued that in some circumstances it might be appropriate for countries to peg their
} 


\section{VI.B.2. Global financial super-regulator (Kaufman)}

Kaufman $(1998 \mathrm{a}, \mathrm{b})$ has proposed the creation of a global super-regulator, i.e., a new international institution that would regulate financial markets and institutions. This institution would supervise and regulate the activities of both traditional banks and nonbanking financial intermediaries. The logic of this proposal is that financial regulation is still at the national level but financial institutions now operate globally and financial markets are globally integrated. Thus, supervision solely at the national level may not be appropriate for firms that do business globally and in markets that are becoming more and more integrated internationally. Indeed, lack of global supervision and regulation may be one cause of the phenomenon of financial contagion.

There are tremendous obstacles - both political/regulatory and economic - to the idea that sovereign governments around the world would give up their right to supervise and regulate their domestic financial institutions. Also, there are issues of the accountability of such a global regulator: to whom would it be accountable and how? But, as the process of financial integration and globalization continues, the cause for more coordination among national regulators is becoming more widely advocated. And, indeed the FSF was created in part as a mechanism of coordination of national regulatory policies in financial markets, in light of the international nature of many regulatory problems. Thus, although the idea of a global superregulator is farfetched, the idea of greater international coordination of national policies of supervision and regulation will gain ground, as the experience with the FSF suggests.

Also, greater integration may lead, over time, to supernational regulation of financial markets. For example, in Europe, the process of monetary and financial integration has opened the issue of whether banking supervision and regulation should be left to national monetary authorities or transferred to the European Central Bank. It is possible that the latter solution might eventually emerge.

One major obstacle to international supervision and regulation of banking systems derives from the safety net function played by national monetary authorities. Such services are provided by domestic monetary authorities only to financial institutions (be they domestic or foreign banks and their branches) that do operate within a country's borders. In exchange for this provision of a safety net (access to the discount window, lender of last resort liquidity support, deposit insurance

and even bailout in case of financial distress) the banking institutions subject themselves to supervision and regulation. But if supervision and regulation were made by an international institution, who would provide the safety net to banking institutions? And, if a systemic banking crisis in a country leads to significant fiscal costs of bailing out that financial system, who would pay the costs? In the current regime of national regulation, each country (i.e., its taxpayers) bear this cost. But if regulation is international and if banking crises occur in spite of such regulation (or because of mistakes in such regulation), who should be bearing the fiscal costs, the domestic taxpayer or the international taxpayer? One could make a case in principle for the latter,

currencies to a basket of different currencies, or seek to keep their currency within a fixed band (a target zone idea along the lines of the European Monetary System - EMS).

${ }^{108}$ E.g., Frankel and Wei (1993) and McKinnon (2000). 
but the political resistance to such a solution appears currently insuperable. ${ }^{109}$ These are complex and difficult questions that have no easy answer.

\section{VI.B.3. Soros proposal for international deposit insurance}

Soros $(1997,1998)$ has proposed the creation of a public international deposit insurance agency that would insure international investors' claims against default. The logic of this proposal is to reduce the risk of self-fulfilling runs when investors panic and fail to roll over short-term claims coming to maturity. Insured claims would not be run on, as they would be safe. To reduce risk of moral hazard, Soros suggests that the amount of insurable claims of each country should be limited to a maximum, with the ceiling set by the IMF based on the soundness of a country's fundamentals. Debtor countries would pay the cost of this insurance scheme by paying an insurance fee when issuing loans, bonds and other claims.

There are a number of issues with this proposal. ${ }^{110}$ Specifically, if the insurance fee is actuarially fair and there are no informational failures, the debtor does not gain anything relative to issuing uninsured bonds. An insured bond would be riskless and have no spread relative to other riskless international bonds (say US treasuries) but the insurance fee would be equal to the spread of that country's debt relative to riskless assets. Thus, after paying the fee, the cost of external borrowing for the country would remain the same. ${ }^{111}$

Also, such schemes are usually not a free lunch. If some claims are insured, others are not. And since a country's ability to pay - i.e., service its external debt - is given (by its resources and expected future foreign exchange receipts), giving seniority to some insured claims means that the spread on the uninsured ones will go up, with no overall benefit for the country in terms of reduced average spread on its external debt. For the same reason, the risk of a run on uninsured claims will go up. Thus, the risk of liquidity runs might be increased rather than reduced. Also, if insurance is such a good idea, why wouldn't private markets be providing such services? Why should a public agency provide it? One needs to argue that externalities and informational asymmetries and failures are very important to derive a rationale for the public provision of such services. Such externalities and asymmetries may be important in practice but designing an international deposit insurance scheme that is incentive-compatible and minimizes moral hazard distortions may be quite challenging.

\section{VI.C.1. Collateral and credit enhancements: creation of value or redistribution of value?}

\footnotetext{
${ }^{109}$ For example, in the debate on dollarization, the U.S. has made clear that the Fed safety net would not be extended under any circumstance to the financial system of a dollarizing country and that the U.S. would not accept taking responsibility for the supervision and regulation of the financial system of a dollarizer. Taking control of supervision and regulation would imply accepting responsibility for problems of the financial system and would put pressure on the Fed to providing safety net services to a foreign financial system. Hence, the U.S. unwillingness to supervise other countries financial system. For a review of dollarization, from a faction in the US Senate that wishes to encourage it, see Schuler (1999).

${ }^{110}$ See also Eichengreen (1999) for a thoughtful discussion.

111 If market prices are different from actuarially fair prices the debtor may gain or lose. Differences in the relative knowledge or ignorance about fundamental risks between the debtor and market providers of insurance may be a channel through which value is created. But one has to recur to externalities or informational failure to make such an argument.
} 
Several authors have suggested the usefulness of collateral and/or credit enhancements as instruments of crisis prevention and crisis resolution (Feldstein (1999a, 2000) and Corrigan (2000)). And indeed, various types of sweeteners and credit enhancements have been part of recent restructuring episodes.

In general, sweeteners (such as collateral and other enhancements) create different levels of formal or informal seniority among private claims that negatively affect other claims (whether private or official) that do not have the same features. As a country's ability to pay, while uncertain, is given, there is usually no free lunch here and provision of greater seniority to some claims comes at the cost of less seniority for other claims. ${ }^{112}$ This burden shifting game, often at the expense of official creditors' claims, can distort debt flows. Deals in which new claims are provided collateral in the form of future exportable receipts are particularly notable and may not be legal (as they may clash with current "negative pledge clauses" in World Bank and MDBs loans). They are a case of burden shifting. Milder forms of seniority upgrades (such as the sovereign taking responsibility for claims of semi-sovereign entities) are also examples of burden shifting. Other seniority upgrades are embedded in the fine print of the new bonds. For example, Ecuador deal's reinstatement of the original principal (i.e. recession of the haircut on principal payments) in the case that the new bonds are restructured down the line is an example of this indirect attempt to provide seniority to the new instruments.

The arguments presented to justify such reinstatement clauses and general seniority upgrades are as follows: a) they are necessary to maximize the chances of a successful deal; b) it is unfair to creditors that instruments that have, as Bradies, already experienced one or more haircuts, will experience another one in the future. But there are several counter-objections to these. First, investors who want to lock in the value of the new bonds (inclusive of any mark to market gains) can do so by selling these new bonds at current market prices; holding them over time implies accepting the credit risk (potential gains and losses) embedded in the underlying claims. Second, as long as such new instruments trade at significant spreads over risk-free assets, it means that they are not risk-free or senior relative to other instruments. If they were formally treated as effectively senior they would trade at much lower spreads relative to risk-free rates. Third, creating degrees of grayness with some restructured claims being informally more senior (but not fully risk-free) than other private and public claims may add to the confusion, and lack of transparency and predictability of the claims. Either new claims have clear collateral (as the Bradies had) and whatever seniority is embedded in them is formally agreed upon so that absolute and relative pricing of different claims can be clearly made; or otherwise, one creates a new system of pseudo senior claims that adds to the pricing uncertainty and unpredictability of the system of debt flows to emerging markets.

More generally, some - like Corrigan (2000) - have suggested that credit enhancements and broad guarantees should be used as an alternative to large official packages of money. In principle, if one wanted to avoid large official packages and minimize the use of semi-coercive PSI scheme, one could think of a world where countries, subject to a run or whose currency is under pressure, could get temporary loans from the private sectors that are guaranteed by the official sector. This, in Corrigan's view, could be a useful alternative to PSI and big official packages. It is, however, not

\footnotetext{
${ }^{112}$ We discuss below the cases where credit enhancements may create value.
} 
clear whether this solution is truly different from a large official package. But conceptually, there is little difference between the IMF directly borrowing from its official shareholders at risk-free rates and lending the proceeds in big packages at approximately risk-free rates to a country in crisis, versus having instead the private sector lend the same amount of money to the country in crisis under a full guarantee of the loan.

The broader conceptual question is whether such enhancements provide any "value" to debtors beyond the direct benefit/transfer to the debtor deriving the implicit subsidy involved in the guarantee. It is not obvious that this is usually the case. Credit enhancements can create value when there is an externality or some informational asymmetry. For example, in a situation with the risk of a liquidity run, official money, either directly or indirectly through private loans that have guarantees may improve welfare by avoiding self-fulfilling runs not justified by fundamentals (such a run being a clear case of a negative externality and market coordination failure). Thus, enhancements may not imply any subsidy cost to the official sector when they prevent avoidable crises. But in those cases, the optimal choice is a large package of official money; the alternative of a fully guaranteed loan is not, in any substantial terms, different from the big official package. Political constraints and resistance to official money apply to the first scheme as easily as the latter.

Informational asymmetries may also create value. In general, the broad analytical literature on securitized credit (see, for example Klapper (2000) for a review) finds that secured loans occur at the expense of unsecured loans, pledging collateral or providing seniority to one lender subordinates the claims of other creditors. But secured lending may have a rationale if there are informational asymmetries (the borrower not being able to otherwise "signal" that its likelihood of defaulting is lower than the one perceived by the market and thus requiring collateral for credible signaling) or other agency problems (as in Jensen and Meckling (1976) case where collateral controls for the agency problem of asset substitution, i.e. borrowers substituting for riskier than for less risky assets). It is not however obvious that these cases systematically apply to sovereign borrowers. Specifically, signaling from the use of collateral may exacerbate the distortions from asymmetric information rather than reducing them. For example, a highly indebted sovereign who is likely and willing to default and is currently unable to borrow more may use the enhancement or collateral to receive new non-defaultable loans; but this new secured lending occurs at the expense of the previous unsecured loans and the shift of collateral (the sovereign/country's assets) to the new loans means that, in the default state, unsecured creditors receive even less than they would have if such collateral had not been provided to the new loans.

But apart from these very specific cases where value is created, credit enhancements do not generally provide value either in theory or in practice. For example, take a loan that is enjoying a partial guarantee (such as a rolling interest rate guarantee as in the 1999 Thailand EGAT loan, one of the first cases of formal World Bank guarantee of a semi-sovereign loan). Conceptually, investors will price this loan correctly; the component that is guaranteed will have a value equivalent to a risk free loan while the uncollateralized/unguaranteed part would have a "stripped" spread equal to that of other unguaranteed loans to the debtor. Thus, while the loans provide a financial benefit to the debtor, the subsidy value of the guaranteed part, there is no extra value created. The 
private sector could have, as well, given the debtor a loan that was not guaranteed at all and the official sector could give the debtor a grant equal to the subsidy value of the guarantee. Generally, the guarantee cannot create extra value beyond this subsidy/transfer.

Some have argued that value can be created in these enhancements but the arguments are not fully convincing. Specifically, the argument that is often made is that, while the guarantee is limited to only part of the cash flow (say a rolling interest payment), the "halo" of safety of the official creditor (an MDB or the World Bank) who is providing the guarantee will fall on the entire loan; as a "pixie dust" effect, the spread on the uncollateralized component of the loan will also be reduced as, it is argued, it is unlikely that the debtor would want to default (and thus trigger the guarantee) on the payments that are guaranteed. But this "halo" effect is, most likely non-existent in practice. First, Brady Bonds did not benefit from such halo for the uncollateralized component of their payment stream. Second, the pricing of the Thai EGAT loan suggests that the halo effect was miniscule: the spread on the uncollateralized part of the loan was not significantly different from that on other non-guaranteed Thai borrowings. Thus, there is little evidence that such enhancement provided in practice value.

Finally, there may be an indirect channel through which "value" is created but if so, this is a distortionary and moral hazard-biased channel. The non-enhanced component of the loan could have a lower (stripped) spread than that on other non-guaranteed instruments only if investors truly perceived the instrument to have lower repayment/default risk than other instruments because of the official sector "halo" on the enhanced component of the loan. But if this is the case, the holders of the non-guaranteed part of the partially guaranteed loan benefit only because this relative seniority occurs at the expense of other creditors, those holding non-guaranteed claims. Thus, again no real value is created: you only get a transfer of value from some creditors to others. Regimes where such fuzzy hierarchies of seniority are created are not efficient. If relative seniority has to be provided, it is efficient if explicit with clear collateral or definition of the position of the asset in the pecking order of claims, not implicit and couched in "halo" effects. Otherwise, incentives are distorted, transparency reduced and creative financial engineering used to stake seniority.

Similar concerns can be expressed for debt restructuring deals where some of the cash flow payments are collateralized with some future foreign currency resources of the country (such as future oil receipts or other export receipts). Such deals do not usually increase the creditworthiness of the country as the ability - as opposed to the willingness - to pay depends on the country's debt relative to its assets inclusive of the discounted values of any future stream of foreign currency receipts. They usually shift seniority to those creditors who get such deals at the expense of other creditors (both private unsecured or official creditors). These collateralized deals may also violate "negative pledge clauses" on World Bank and other MDBs loans.

\section{VI.C.2. Alternative ideas for the process of debt restructuring}

Many investors and creditors have expressed unhappiness with the current process of bonded debt restructurings (i.e., the model of "debt exchange offers preceded by market soundings") in spite of the success of recent restructurings based on this model (see section II.B). In their view, the current process is unfair, it does not include enough 
of their input, it does not allow for a meaningful negotiation with the debtor and official creditors on the allocation of the burden sharing pie, and it biases the negotiating power in favor of the debtor, thus undermining the incentives to service in full and on time debt payments. Some (for example, a group that was sponsored by the Council on Foreign Relations -- CFR) accordingly suggest that an alternative process should be followed in such restructurings based on creditor committees and more formal negotiations. ${ }^{113}$ In this alternative process, an ad-hoc group of bondholders (and possibly other creditors) would be formed and a formal negotiation with the debtor would take place. Some also suggest that the negotiations should be extended to official creditors to ensure that the private sector is not a residual claimant but rather has a say in how much of the burden will be borne by private creditors compared to public creditors. To sweeten this shift in alleged bargaining power to private creditors, it has been suggested that creditors may be willing, in exchange for formal committees and negotiations, to accept a voluntary debt standstill accompanied by a legally enforceable stay of litigation.

In contrast to this proposal, critics agree that it is not clear that, in debt exchanges, too much bargaining power is shifted to debtors. In fact, such offers are voluntary in the sense that the debtor has to offer terms that maximize the probability that a large fraction (often formally over $85 \%$ ) of creditors accept it. Thus, if one looks at recent bond restructuring episodes (Ukraine, Pakistan, Russia and Ecuador) one can observe that the terms of the restructured bonds have been extremely generous and have provided significant mark-to-market gains to creditors who have accepted such offers. Advisors make extensive market soundings before the offer is launched to figure out the preferences of creditors for the type, terms and conditions of the restructured instruments. It is thus not clear that an alternative process based on formal negotiations would provide a smaller slice of the burden pie to creditors.

Second, formal negotiations with debtors run the risk of dragging on indefinitely and inflicting "delay losses" on both creditors and debtors. A situation where debts are in default for protracted periods of time is highly disruptive to debtors as cutoff from market access, output losses and other real costs accumulate over time. Such losses eventually hurt the debtor's ability to pay and are thus costly to creditors as well.

Third, there are serious obstacles and disadvantages to the idea that creditors could be involved in the decision of how much adjustment the debtor would do, how much official multilateral support would be provided and how much of the sharing burden would be borne by the Paris Club creditors. ${ }^{114}$

\footnotetext{
${ }^{113}$ This is a different group from the task force that, under the CFR umbrella, proposed a framework for the reform of the international financial architecture. For reasons of space, we do not discuss the proposals of this group presented in a report (Independent Task Force (1999)). These proposals are conceptually, in between the radical reforms of the Meltzer Commission and the gradualist changes agreed upon by the G7 and the IMF. For example, the CFR suggest a smaller use of large IMF packages and a greater reliance on more coercive forms of PSI but it does not go as far as the Meltzer Commission in regards to restricting the ability of the IMF to provide lending in crises episodes. Also the CFR task force expressed some sympathy for a more formally structured restructuring process (creditor committees, negotiations and collective action clauses) that is consistent with some of the views of the other CFR group initiative discussed in the text.

${ }^{114}$ See Roubini (2000) for a detailed discussion of these objections. In general, most private sector participants agree that their involvement in the first two steps, design of macro policy adjustment effort and amount of multilateral support is not likely to occur; but they would like to be involved in the last step, the discussion of the relative role of official bilateral creditors (Paris Club) and private sector in burden sharing and a direct negotiation with the debtor on the terms of a restructuring.
} 
Fourth, bilateral market soundings between debtors and creditors appear to have worked satisfactorily in Pakistan, Ukraine and Russia. If anything the experience of the Ecuador Consultative Group where the debtor regularly met with a broad representation of bondholders has been criticized as unproductive and unsuccessful. It became, at times, an unconstructive forum where frustrated creditors vented their unhappiness with the slowness of the adjustment and restructuring process rather than a productive procedure to accelerate the restructuring. Sometimes, bilateral soundings are more efficient than large public fora where both sides posture to stake their claims.

Fifth, it is not obvious that one restructuring process provides more incentive for strategic non-payments or defaults than another. In the debt exchange offer model, the debtors are usually very wary of stopping payments to private creditors and would rather avoid non-payment for as long as possible as the economic (and legal) costs of such a formal default can be very high: loss of output, loss of market access, trade sanctions, et cetera. It is not clear why a formal negotiating process (especially one where standstills are sanctions and stays of litigation imposed) would provide lower bargaining power to the debtor. It is ambiguous in theory and in practice whether either process has a systematic effect on the relative bargaining power of debtors versus creditors. Indeed, some processes that would lead to delay in negotiations may be negative-sum games where inefficient costs of delay impose welfare losses on both debtors and creditors. Thus, a system of debt exchange with market soundings may be beneficial to all.

In conclusion, it is not obvious that an alternative process based on negotiations and formal creditor committees would be in the interest of creditors. ${ }^{115}$ It would certainly be worthwhile, however, to study alternative process schemes and improve on existing ones. For example, the current system of "market soundings" has been somewhat unstructured. Maybe a more structured process would contribute to providing financial advisors with the information necessary to design successful debt exchanges. Also, while negotiations between private and official creditors are not likely to occur, there may be ways to improve the flow of information to the private sector. Official creditors could be more clear about the PSI doctrine and its application; the Paris Club could become somewhat more transparent and explain better its procedures and terms for restructuring; ${ }^{116}$ the debtor country should provide information to creditors in good and bad times and keep them fully informed of economic prospects, external debt and payment stream data, economic forecasts, possible external financing problems and plans to address these problems; and the IMF could have a closer dialogue with the private sector and more regularly brief investors of program developments for a debtor country with external debt servicing problems. All these steps would increase transparency, openness, and predictability of PSI and reduce the impression that the process is arbitrary and unpredictable. Constructive ideas along these lines could improve the current system and support the cooperative goals of the PSI policy.

\footnotetext{
${ }^{115}$ But the official sector remains open to the idea that creditors' committees and negotiations between creditors and debtors may be at times an appropriate mechanism to restructure sovereign bonded debt liabilities; see Geithner (2000).

${ }^{116}$ The Paris Club has indeed recently opened a Web site (http://www.clubdeparis.org/) where information is provided to investors about its activities, rules, procedures and decisions.
} 


\section{Conclusions}

The emerging market countries might have reacted to the crises they suffered in the late 1990s by challenging the legitimacy of the world financial system, charging that it was rigged to benefit rich-country investors. For the most part this has not happened. True, they complain that they deserve better representation in the governance structure than they have received in the past. True, the crises made it more difficult to claim that free financial markets operate with perfect efficiency. True, improvements in the system are both desirable and possible. Nevertheless most countries everywhere now agree that a global capitalist system best promotes growth. Furthermore, few can deny the practical realities that give heavy weight to the United States and other G-7 countries as a steering committee in the governance of that system - the logistical advantages of small numbers and the power dynamics of creditor-debtor relationships.

This chapter has reviewed the role of the major industrialized countries in three areas: (1) their own macroeconomic policies, which determine the global financial environment; (2) their role in responding to crises when they occur, particularly through rescue packages with three components --reforms in debtor countries, public funds from creditor countries, and private sector involvement; and (3) efforts to reform the international financial architecture, with the aim of lessening the frequency and severity of future crises. The latter two topics are closely intertwined, due to tension between mitigating crises in the short run, and the moral hazard that rescues create in the longer term.

The phrase "new Bretton Woods," or even "new financial architecture," may be too grand to connote the reform initiatives that have been undertaken for the future. These reforms are modest and incrementalist, rather than sweeping and revolutionary perhaps more like redoing the plumbing and electricity in the house than redesigning the architecture from the ground up. But they might nonetheless contribute to crisis prevention and resolution. If all the PSI reforms are successfully implemented, crises when they occur may be better managed and resolved at lower costs. If all the crisisprevention reforms are successfully implemented, the system may become less prone to crises in the first place. This will take years. It would be foolish to think that reforms already in progress will eliminate the risk of crises in emerging markets. Some degree of volatility is inevitable - perhaps even a higher degree of volatility at early stages of a poor country's liberalization and industrialization than would prevail if it remained economically isolated and undeveloped. The United States had severe financial and economic crashes during its period of industrialization. Perhaps the rest of the world will settle down to a stable and tranquil path only when its markets and institutions are as well developed as those of the United States today.

\section{$\underline{\text { References }}$}

Bhagwati, Jagdish (1998) "Fifty Years: Looking Back, Looking Forward," Paper written for the Symposium on the World Trading System, organized by the WTO and the Graduate Institute of International Studies, Geneva, April 30. 
Bagci, P. and W. Perrudin (1997) “Do IMF Programs Work?” Global Economic Institutions Working Paper.

Becker, Torbjorn, Anthony J. Richards and Yungong Thaicharoen (2000), "Collective Action Clauses for Emerging Market Bonds: Good News for Lower Rated Borrowers Too," unpublished manuscript, IMF.

Bergsten, F. (2000) Minority dissent on the Report of the International Financial Institution Advisory Commission ("Meltzer Commission"), Washington, D.C.

Bird, Graham and Dane Rowlands (1997), "The Catalytic Effects of Lending by the International Financial Institutions," World Economy, pp.967-991.

Bordo, Michael D. and Anna J. Schwartz (2000) "Measuring Real Economic Effects of Bailouts: Historical Perspectives on How Countries in Financial Distress Have Fared With and Without Bailouts, "NBER

Working Paper No. 7701, May.

Bucheit Lee (2000a) "Sovereign Debtors and their Bondholders," Unitar Training Programmes on Foreign Economic Relations, Document No.1 (Geneva: Unitar).

Bucheit, Lee, and G. Mitu Gulati (2000b) "Exit Consents in Sovereign Bond exchanges," UCLA Law Review, Vol. 48 (October) pp. 59-84.

Buiter, Willem H. and Anne C. Sibert (1999), "UDROP: A Small Contribution to the New International Financial Architecture,” International Finance 2, pp.227-248.

Bulow, Jeremy I., and Kenneth Rogoff, (1989) "A Constant Recontracting Model of Sovereign Debt," Journal of Political Economy, Vol. 97 (February) pp. 155-178.

Calvo, Guillermo, Leo Leiderman and Carmen Reinhart (1993) "Capital Inflows and Real Exchange Rate Appreciation in Latin America: The Role of External Factors," IMF Staff Papers 40, no.1, March, pp.108-150.

Calvo, Guillermo, Leo Leiderman and Carmen Reinhart (1994a) "The Capital Inflows Problem: Concepts and Issues," Contemporary Economic Policy XII, July, 54-66.

Calvo, Guillermo, Leo Leiderman and Carmen Reinhart (1994b) "Capital Inflows to Latin America: The 1970s and the 1990s," forthcoming in Edmar Bacha, ed., Development, Trade and the Environment, London: MacMillan Press.

Calomiris, Charles (1998a) “The IMF's Imprudent Role as Lender of Last Resort,” Cato Journal, 17, pp.275-295.

Calomiris, Charles (1998b) "Blueprints for a New Global Financial Architecture," unpublished, Columbia University.

Checki, Terrence J. and Ernest Stern "Financial Crises in the Emerging Markets: The Roles of the Public and Private Sectors," Federal Reserve Bank of New York, November.

Chinn, Menzie D., Michael P. Dooley, Sona Shrestha (1999) "Latin America and East Asia in the Context of an Insurance Model of Currency Crises NBER Working Paper No. W7091, April.

Chuhan, Punam, Stijn Claessens and Nlandu Mamingi (1994) "Equity and Bond Flows to Latin America and Asia: The Role of Global and Country Factors," The World Bank, October. 
Clarida, Richard, 2000, "G3 Exchange Rate Relationships: A Recap of the Record and a Review of Proposals for Change,” NBER Working Paper No. 7434, December 1999. Essays in International Economics No. 219, Princeton University Press, September.

Cline, William, 1984, International Debt: Systemic Risk and Policy Response, Institute for International Economics, Washington DC.

Cline, William, 1995, International Debt Reexamined, Institute for International Economics, Washington DC.

Cline, William (2000) The Role of the Private Sector in Resolving Financial Crises in Emerging Markets"; in this volume.

Cline, William (2000) "The Role of the Private Sector in Resolving Financial Crises in Emerging Markets", Institute of International Finance (Washington: IIF, October), mimeo.

Council on Foreign Relations, 1999, Safeguarding Prosperity in a Global Financial System: The Future International Financial Architecture, published by Institute for International Economics, Washington, DC, 1999.

Conway, P. (1994) "IMF Lending Programs: Participation and Impact," Journal of Development

Economics, 45, December, pp.365-391.

Corrigan, E. Gerald (2000), "Two International Financial Stability Issues: Asset Price Inflation and Private Sector participation in Financial Crisis Stabilisation," Financial Stability Review (June), pp.136-141.

Corsetti, Pesenti and Roubini (1999a) "What Caused the Asian Currency and Financial Crisis, Japan and the World Economy, September.

Corsetti, Pesenti and Roubini (1999b) "Paper Tigers? A Model of the Asian Crisis," European Economic Review, July 1999.

Corsetti, Pesenti and Roubini (2001) “The Role of Large Players in Currency Crises," unpublished, New York University, January.

Dallara, Charles (1999), "Letter to the Chairman of the Interim Committee," 16 September, http://www.iif.com.

De Gregorio, Jose, Barry Eichengreen, Takatoshi Ito and Charles Wyplosz, 1999, "An Independent and Accountable IMF," in Geneva Report on the World Economy, June.

Diaz-Alejandro, Carlos, 1985, "Good-bye Financial Repression, Hello Financial Crash,” Brookings Papers on Economic Activity, 19, Sept.-Oct., 1-24.

Dominguez, Kathryn, and Jeffrey Frankel, Does Foreign Exchange Intervention Work? Institute for International Economics, Washington, D.C., 1993.

Dooley, Michael, Eduardo Fernandez-Arias, and Kenneth Kletzer, 1994, "Recent Private Capital Inflows to Developing Countries: Is the Debt Crisis History?" NBER Working Paper No. 4792, July.

Dornbusch, Rudiger, 1985, "Policy and Performance Links Between LDC Debtors and Industrial Nations," Brookings Papers on Economic Activity 2, Washington DC: The Brookings Institution.

De Gregorio, José, Barry Eichengreen, Takatoshi Ito and Charles Wyplosz (1999) “An Independent and Accountable IMF," Geneva Reports on the World Economy, September, CEPR. 
Dell'Ariccia, Giovanni, Isabel Goedde and Jeromin Zettelmeyer (2000) "Moral Hazard in International Crisis Lending: A Test", International Monetary Fund, November.

Deutsche Bundesbank (1999), "Recent Approaches to Involving the Private Sector in the Resolution of International Debt Crises," Monthly Report (December), pp.3348.

Dicks-Mireaux, L., M. Mecagni and S. Schadler (1997) "Evaluating the Effect of IMF Lending to Low Income Countries," IMF Unpublished.

Dixon, Liz and David Wall (2000), "Collective Action Problems and Collective Action Clauses, " Financial Stability Review (June), pp.142-151.

Dooley Michael (1997), “A Model of Crises in Emerging Markets,” NBER Working Paper no. 6300

December.

Dooley, Michael (2000), “Can Output Losses Following International Financial Crises Be Avoided?" NBER Working Paper no. 7531 (February).

Drage, J. and F. Mann (1999), "Improving the Stability of the International Financial Sector," Financial Stability Review (June), pp.40-77.

Economist (1999), "Sovereign Policy," The Economist, February 13, p. 21.

Edwards, Sebastian (2000) “Exchange Rate Regimes, Capital Flows, and Crisis Prevention,”; in this volume.

Edwards, Sebastian, 2000, "Exchange Rate Regimes," forthcoming in this volume, Economic and Financial Crises in Emerging Market Economies, edited by Martin Feldstein, 2002.

Eichengreen, Barry, 1999, Toward a New Financial Architecture: A Practical Post-Asia Agenda, Institute for International Economics, Washington, DC.

Eichengreen, Barry, 1999a, "Toward a New International Financial Architecture: A Practical Post-Asia Agenda" (Washington: Institute for International Economics).

Eichengreen, Barry (1999b) “Is Greater Private-Sector Burden Sharing Impossible?,” University of California, Berkeley, May.

Eichengreen, Barry (2000) "Can the Moral Hazard Caused by IMF Bailouts be Reduced," Geneva Reports on the World Economy Special Report 1 (Geneva: International Center for Monetary and Banking Studies).

Eichengreen, Barry and Ashoka Mody (2000a), "Would Collective Action Clauses Raise Borrowing Costs?” NBER Working Paper no.7458 (January).

Eichengreen, Barry and Ashoka Mody (2000b), "Would Collective Action Clauses Raise Borrowing Costs? An Update and Additional Results," Policy Research Working Paper no. 2363, Washington, D.C.: The World Bank (June).

Eichengreen, Barry and Richard Portes (1995), Crisis? What Crisis? Orderly Workouts for Sovereign Debtors, London: CEPR.

Eichengreen, Barry, and Andrew Rose "Staying Afloat When the Wind Shifts: External Factors and Emerging-Market Banking Crises," NBER Working Paper 6370; forthcoming in Money, Factor Mobility and Trade: Essays in Honor of Robert Mundell, edited by Guillermo Calvo, Rudiger Dornbusch and Maurice Obstfeld. 
Eichengreen Barry and Ruhl (2000) “The Bail-In Problem: Systematic Goals, Ad Hoc Means," NBER Working Paper No. W7653, April.

Faini, Ricardo, Jaime de Melo, A. Senhadji-Semlali and J. Stanton (1991), "Macro Performance Under Adjustment lending," in V. Thomas, A Chibber, M. Dailami and J. de Melo (eds), Restructuring Economies in Distress: Policy Reform and the World Bank, Washington, D.C.: The World Bank, pp.222-242.

Feldstein, Martin, 1994, "American Economic Policy in the 1980s: A Personal View," in American Economic Policy in the 1980s, edited by Martin Feldstein, University of Chicago Press, Chicago, 1994, pp. $1-79$.

Feldstein, Martin (1999a) “Self-Protection for Emerging Market Economies," NBER Working Paper No. 6907, January.

Feldstein, Martin (1999b) "Refocusing the IMF," Foreign Affairs.

Feldstein, Martin (2000) “Aspects of Global Economic Integration: Outlook for the Future,” NBER Working Paper No. 7899, September.

Fernandez-Arias, Eduardo, 1994, "The New Wave of Private Capital Inflows: Push or Pull?" Policy Research Working Paper 1312, Debt and International Finance Division, International Economics Department, The World Bank, June.

Fischer, Bernhard, and Helmut Reisen, 1994, "Pension Fund Investment From Ageing to Emerging Markets," OECD Development Centre Policy Brief No. 9, Paris.

Fischer, Stanley (1999), "Learning the Lessons of Financial Crises: The Roles of the Public and Private Sectors,' Speech to the Emerging Market Traders' Association Annual Meeting, New York (December 9), http://www.imf.org/external/np/speeches/1999/120999.HTM.

Fischer, Stanley (2000) "Managing the International Monetary System, International Monetary Fund, July.

Frankel, Jeffrey, and David Romer, 1999, "Does Trade Cause Growth?" American Economic Review 89, no. 3, June 1999, 379-399.

Frankel, Jeffrey, and Andrew Rose, 1996, "Currency Crashes in Emerging Markets: An Empirical Treatment," Journal of International Economics 41, no. 3/4, 351-366.

Frankel, Jeffrey, and Shang-Jin Wei, 1993, "Is Japan Creating a Yen Bloc in East Asia and the Pacific?" in Regionalism and Rivalry: Japan and the U.S. in Pacific Asia, edited by Jeffrey Frankel and Miles Kahler, University of Chicago Press, Chicago, 53-85.

Frankel, Jeffrey, and Chudozie Okongwu, 1996, "Liberalized Portfolio Capital Inflows in Emerging Markets: Sterilization, Expectations, and the Incompleteness of Interest Rate Convergence," International Journal of Finance and Economics 1, no. 1, Jan., 1-23.

Friedman, Benjamin (2000), "How Easy Should Debt Restructuring Be?" in Charles Adams, Robert Litan and Michael Pomerleano (eds), Managing Financial and Coporate Distress: Lessons from Asia, Washington, D.C.: The Brookings Institution, pp.21-46.

Geithner, Timothy (2000) "Resolving Financial Crises in Emerging Market Economics"; Remarks before the Securities Industry Association and Emerging Markets Trades Association New York, NY, October 23

Goldstein, Morris, 1997, The Case for an International Banking Standard, Policy Analyses in International Economics 47, April, Institute for International Economics: Washington DC. 
Goldstein, Morris, Graciela Kaminsky and Carmen Reinhart, 2000, Assessing Financial Vulnerability: An Early Warning System for Emerging Markets, Institute for International Economics: Washington DC, June.

Goldstein, Morris and Mohsin Khan, 1985, "Income and Price Effects in Foreign Trade," in Handbook of International Economics vol.II, R.Jones and P.Kenen, eds. (Elsevier), Ch.20, 1041-1105.

Goldstein, Morris (2000), "IMF Structural Programs," unpublished paper, Institute for International Economics, October.

Griffith-Jones, Stephany, Jose Antonio Ocampo and Jacques Cailloux (1999), "The Poorest Countries and the Emerging International Financial Architecture," unpublished manuscript, Swedish Ministry of Foreign Affairs.

Group of Seven (1999), Strengthening the International Financial Architecture, Washington, D.C.: Group of Seven.

Group of Seven (2000) "Strengthening the International Financial Architecture", Report from G7 Finance Ministers to the Heads of State and Government. July 21.

Group of Ten (1996), Resolving Sovereign Liquidity Crises, London: Group of Ten.

Group of Twenty Two (1998), Report of the Working Group on International Financial Crises, Washington, D.C.: Group of Twenty Two.

Haldane, Andy, 1999, "Private Sector Involvement in Financial Crisis: Analytics and Public Policy Approaches," Financial Stability Review, Bank of England (November).

Haque, Nadeem Ul and Mohsin Kahn (1999) "Do IMF-Supported Program Work? A Survey of the CrossCountry Empirical Evidence," IMF WP No.98/169, December, Washington D.C.

Henning, C. Randall, 1999, The Exchange Stabilization Fund: Slush Money or War Chest? Policy Analyses in International Economics No. 57, Institute for International Economics, Washington DC, May.

Independent Task Force (1999) "Safeguarding Prosperity in a Global Financial System: The Future International Financial Architecture" Report of an Independent Task Force sponsored by the Council on Foreign Relations".

Institute of International Finance (1996), Resolving Sovereign Financial Crises, Washington, D.C.: Institute of International Finance.

Institute of International Finance (1999a), "Global Private Finance Leaders Stress the Importance of Voluntary Approaches to Crisis Resolution in Emerging Markets," 24 June, http://www.iif.com/PressRel/1999pr9.html.

Institute of International Finance (1999b), "Summary Report on the Work of the IIF Steering Committee on Emerging Markets Finance,” Washington, D.C.: Institute of International Finance.

Institute of International Finance (1999c) "Testing for "Moral Hazard" in Emerging Markets Lending," IIF Research Papers No. 99-1, August.

International Financial Institution Advisory Commission (2000) Report of the International Financial Institution Advisory Commission ("Meltzer Commission"), Washington, D.C.

International Monetary Fund (1999) "Involving the Private Sector in Forestalling and Resolving Financial Crises," Policy Development and Review Department (Washington: IMF, April). 
, 2000a, International Capital Markets: Developments, Prospects, and Key Policy Issues, World Economic and Financial Surveys (Washington:IMF, September).

, 2000b, "Involving the Private Sector in the Resolution of Financial Crises - Standstills -

Preliminary Considerations," Policy Development and Review Department and Legal Department (Washington:IMF, September).

Kahn, Robert (2000), “The Role of the Private Sector in the Prevention and Resolution of International Financial Crises," presentation to the Conference on the Governance of the Global Capital Market, Montreal, 23 October.

Kaufman, Henry (1998a) "Preventing the Next Global Financial Crisis," Washington Post, January 27, p. A17.

Kaufman, Henry (1998b) "Proposal for Improving the Structure of Financial Supervision and Regulation," Outline of remarks before the Brookings Institution Symposium on Limiting Moral Hazard in Financial Rescues, June 4, Washington.

Kenen, Peter, The International Financial Architecture: What's New? What's Missing?, Princeton Univesity, June 2001. Forthcoming, Institute for International Economics, Washington DC.

Killick, Tony (1995), IMF Programmes in Developing Countries: Design and Impact, London: Routledge/ODI.

King, Mervyn (1999) On corner solutions of full bail-outs or full bail-ins.

Klepper, Leora (2000) “The Uniqueness of Short-Term Collateralization”, World Bank Working Paper.

Köhler, Horst (2000) “Toward a More Focused IMF”, July, IMF.

Kaufman, Henry, 1999, "Preventing the Next Global Financial Crisis," Washington Post, Jan. 28, p.A17.

Krueger, Anne, 1997, "Whither the World Bank and the IMF," NBER Working Paper No. 6327, December.

Lane, Timothy, and Steven Phillips (2000) "Does IMF Financing Result in Moral Hazard?", IMF Working Paper WP/00/168 (Washington:IMF, October).

Levinson (2000) Dissent on the Report of the International Financial Institution Advisory Commission ("Meltzer Commission"), Washington, D.C.

Lindenbaum, Eric, and Alicia Duran, 2000, "Debt Restructuring: Legal Considerations - Impact of Peru's Legal Battle and Ecuador's Restructuring on Nigeria and Other Potential Burden Sharing Cases," (New York: Merrill Lynch \& Co., October).

McKinnon, Ronald and Huw Pill (1997), "Credible Economic Libeeralizations and Overborrowing," American Economic Review Papers and Proceedings 87, pp.189-193.

McQuillan, Lawrence and Peter Montgomery (1999) (eds.) The International Monetary Fund: Financial Medic to the World? Hoover Press, Stanford CA, 1999, p.197-200.

Meltzer, Allan (1998) "Asian Problems and the IMF," Testimony prepared for the Joint Economic Committee, US Congress, February 24, Washington. 
Miller, Marcus and Joseph Stiglitz (1999), "Bankruptcy Protection Against Macroeconomic Shocks: The Case for a 'Super Chapter 11'," unpublished manuscript, the World Bank.

Mody, Ashok, Mark Taylor and Jung Yeon Kim (2001), Modelling Fundamentals for Forecasting Capital Flows to Emerging Markets," International Journal of Finance and Economics, 6, no. 3, July, 201-216.

Murray, John (2000), "The Role of the Private Sector in the Prevention and Resolution of International Financial Crises," presentation to the Conference on the Governance of the Global Capital Market, Montreal, 23 October.

McKibbin, Warwick, and Jeffrey Sachs. 1988. Coordination of monetary and fiscal policies in the industrial economies. In International Aspects of Fiscal Policies. Edited by Jacob Frenkel, pp. 73-120. Chicago: University of Chicago Press.

McKibbin, Warwick, and Jeffrey Sachs. 1991. Global Linkages: Macroeconomic Interdependence and Cooperation in the World Economy, Brookings Institution, Washington, D.C.

McKinnon, Ronald, 2000, “After the Crisis, the East Asian Dollar Standard Resurrected," Stanford University, August.

Niehans, Jurg "How to Fill an Empty Shell (in The International Monetary Mechanism: Recent Problems and Evidence)" American Economic Review, Vol. 66, No. 2, Papers and Proceedings (May 1976), pp. 177-183.

Ozler, Sule (1993), “Have Commercial Banks Ignored History?” American Economic Review 83, pp.608620 .

Obstfeld, Maurice, 1994, "The Logic of Currency Crises," Cahiers Economiques et Monetaires, 43, 189213.

Obstfeld, Maurice, 1995. "Models of Currency Crises with Self-Fulfilling Features," NBER WP 5285.

Petas, Peter, and Rashique Rahman, 1999, "Sovereign Bonds-Legal Aspects that Affect --Default and Recovery ," Global Emerging Markets-Debt Strategy (London: Deutsche Bank, May).

Portes, Richard (2000) "Sovereign Debt Restructuring: The Role of Institutions for Collective Action," mimeo, London Business School, March.

Prusa, Thomas, 2000, “On the Spread and Impact of Antidumping,” NBER Working Paper No. 7404.

Rogoff, Kenneth, 1999, "International Institution for Reducing Global Financial Instability" NBER

Working Paper 7265, July. Journal of Economic Perspectives, Vol. 13, no. 4 (Fall 1999): 21-42.

Rubin, Robert, 1998. "Strengthening the Architecture of the International Financial System," U.S. Treasury, April 14.

Roubini, Nouriel, 2000, "Bail-In, Burden-Sharing, Private Sector Involvement (PSI) in Crisis Resolution and constructive Engagement of the Private Sector. A Primer: Evolving Definitions, Doctrine, Practice and Case Law", (New York, Stern School of Business, New York University, unpublished).

Rowlands, Dane (1994), “The Response of new Lending to the IMF," Developing Studies Working Paper 7, Norman Paterson School of International Affairs.

Rubin, Robert (1998) "Strengthening the architecture of the international financial system"; remarks to the Brookings Institution, April 14. 
Sachs, Jeffrey. 1985. "The dollar and the policy mix: 1985," Brookings Papers on Economic Activity 1: 117-197.

Sachs, Jeffrey, 1986, "Managing the LDC Debt Crisis," Brookings Papers on Economic Activity 2, 397432 .

Sachs, Jeffrey (1994), “Do We Need an International Lender of Last Resort?” unpublished manuscript, Harvard University.

Schott, Jeffrey, 1998, "The World Trade Organization: Progress to Date and the Road Ahead," in J. Schott, ed., Launching New Global Trade Talks: An Action Agenda, Institute for International Economics:

Washington DC.

Schuler, Kurt, 1999, Basics of Dollarization, Joint Economic Committee Staff Report, US Congress, January (updated Jan. 2000).

Schultz, George, William Simon, and Walter Wriston, "Who Needs the IMF," Wall Street Journal, Feb. 3, 1998. Reprinted in The International Monetary Fund: Financial Medic to the World? edited by Lawrence McQuillan, and Peter Montgomery, Hoover Press, Stanford CA, 1999, p.197-200.

Schwartz (1998) "Time to Terminate the ESF and the IMF," CATO Institute Foreign Policy Briefing No.48, August, Washington: CATO Institute.

Soros, George (1997) “Avoiding a Brakdown: Asia’s Crisis Demands a Rethink of International Regulation," Financial Times, December 31, page 12.

Soros, George (1998) “The Crisis of Global Capitalism,” New York: Public Affairs Press.

Subramanian, Arvind, 1999, "Intellectual Property Rights," Proceedings from conference on Developing Countries and the New Round of Multilateral Trade Negotiations, Harvard University, November 5-6, 1999.

Summers, Lawrence (1999), "The Right Kind of IMF for a Stable Global Financial System," Text as Prepared for Delivery to the London School of Business, 13 December, http://www.ustreas.gov/press/releases/ps294.htm.

Summers, Lawrence H. (2000) “International Financial Crises: Causes, Prevention, and Cures," American Economic Review, Papers and Proceedings, May 2000, pp.1-16.

Tsatsaronis, Costas (1999), "The Effects of Collective Action Clauses on Sovereign Bond Spreads," BIS Quarterly Review (November), pp.22-23.

Treasury (2000) "Response to the Report of the International Financial Institution Advisory Commission", United States Treasury Department, Washington, D.C., June.

Yanni, A. (1999), "Resolution of Sovereign Financial Crisis - Evolution of the Private Sector Restructuring Process," Financial Stability Review (June), pp.78-84.

Wang, Zhen Kun, and L Alan Winters, 2000, "Putting 'Humpty' Together Again: Including Developing Countries in a Consensus for the WTO," Centre for Economic Policy Research Policy Paper No. 4, London.

Woodward, Bob, "Maestro: Greenspan's Fed and the American Boom (Simon and Schuster, NY), 2000. 
Zettelmeyer, Jeromin, 2000, "Can Official Crisis Lending be Counter-productive in the Short-Run?," Economic Notes, Vol. 29 (February), pp. 13-29. 